\title{
Technical Considerations for Evaluating Substantially Complete Containment of High-Level Waste Within the Waste Package
}

Manuscript Completed: November 1990

Date Published: December 1990

Prepared by

H. K. Manaktala, Center for Nuclear Waste Regulatory Analyses

C. G. Interrante, U.S. Nuclear Regulatory Commission

Center for Nuclear Waste Regulatory Analyses

Southwest Research Institute

6220 Culebra Road

San Antonio, TX 78228

Prepared for

Division of High-Level Waste Management

Office of Nuclear Material Safety and Safeguards

U.S. Nuclear Regulatory Commission

Washington, DC 20555

NRC FIN D1035 


\begin{abstract}
This report deals with technical information that is considered essential for demonstrating the ability of the high-level radioactive waste package to provide "substantially complete containment" of its contents (vitrified waste form or spent light-water reactor fuel) for a period of 300 to 1000 years in a geological repository environment. The discussion is centered around technical considerations of the repository environment, materials and fabrication processes for the vaste package components, various degradation modes of the materials of construction of the waste packages, and inspection and monitoring of the waste, package during the preclosure and retrievability period, which could begin up to 50 years after initiation of waste emplacement. The emphasis in this report is on metallic materials. However, brief references have been made to other materials such as ceramics, graphite, bonded ceramic-metal systems, and other types of composites. The content of this report was presented to an external peer review panel of nine members at a workshop held at the Ceiter for Nuclear Waste Regulatory Analyses (CNWRA), Southwest Research Institute, San Antonio, Texis, April 2-4, 1990. The recommendations of the peer review panel have been incorporated in this report. There are two companion reports; the second report in the series provides state-of-the-art techniques for uncertainty evaluations. The methods provided in that report can be used to quantify various types of uncertainties. The third companion report, on the basis of the information provided in the first two reports, develops recommendations for the resolution of the issue of "substantially complete containment" of high-level radioactive waste within the waste package, as addressed in 10 CFR Part 60.
\end{abstract}




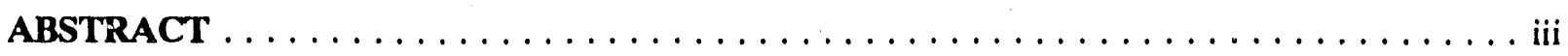

EXECUTIVE SUMMARY $\ldots \ldots \ldots \ldots \ldots \ldots \ldots \ldots \ldots \ldots \ldots \ldots \ldots \ldots$ vii

ACKNOWLEDGMENTS $\ldots \ldots \ldots \ldots \ldots \ldots \ldots \ldots \ldots \ldots \ldots \ldots \ldots \ldots \ldots \ldots$

1. INTRODUCTION $\ldots \ldots \ldots \ldots \ldots \ldots \ldots \ldots \ldots \ldots \ldots \ldots \ldots \ldots \ldots \ldots$

2. APPROACH TO REDUCING AMBIGUITY RELATED TO SUBSTANTIALLY COMPLETE CONTAINMENT (SCC) $\ldots \ldots \ldots \ldots \ldots \ldots \ldots \ldots \ldots$

3. TECHNICAL CONSIDERATIONS $\ldots \ldots \ldots \ldots \ldots \ldots \ldots \ldots \ldots \ldots \ldots \ldots$

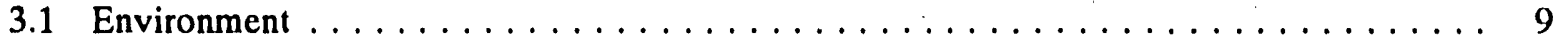

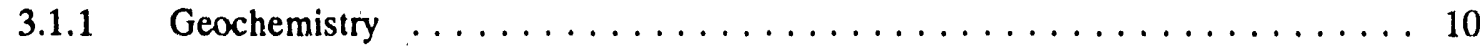

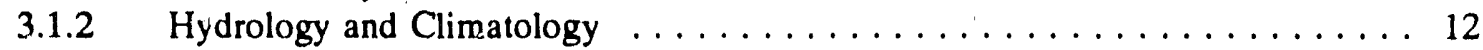

3.1.3 Geology ............................ 14

3.1.4 Volcanic and Seismic Hazards . . . . . . . . . . . . . . . . 17

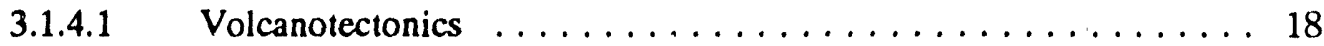

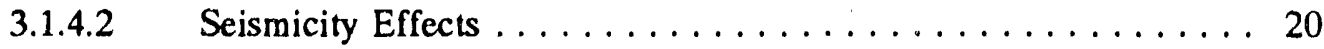

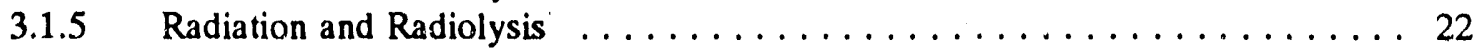

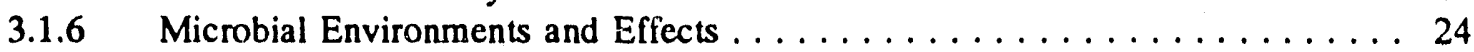

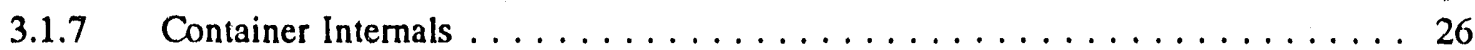

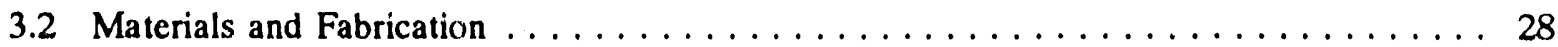

3.2.1 Quality Control ............................... 29

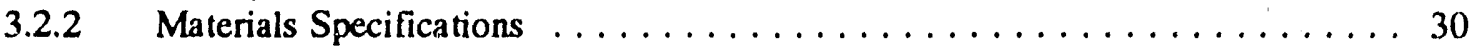

3.2.3 Materials Characterization ....................... 32

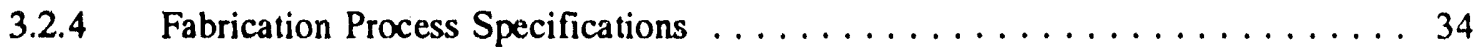

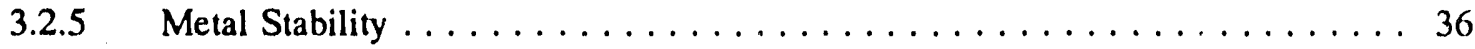

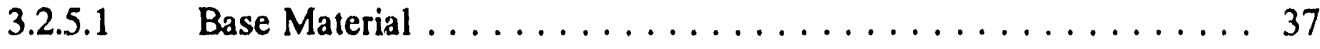

3.2.5.2 Weldments ........................ 39

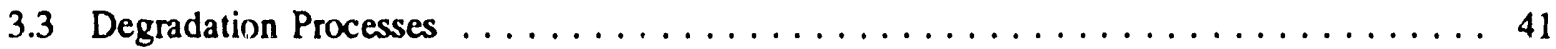

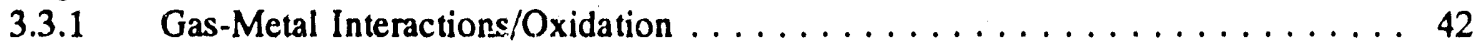

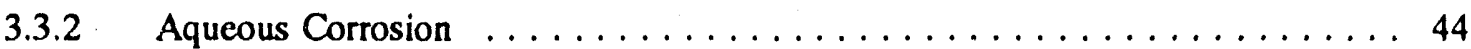

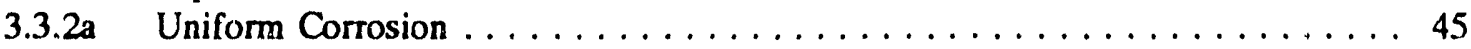

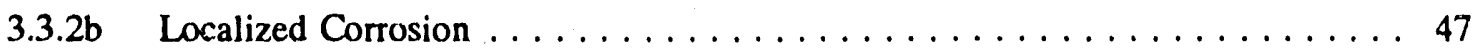

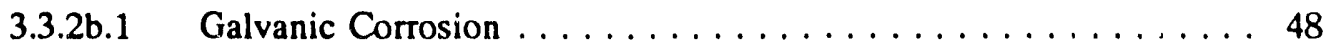

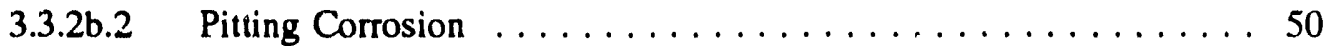

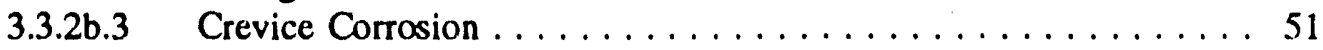

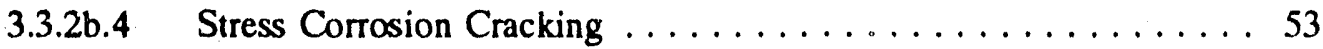

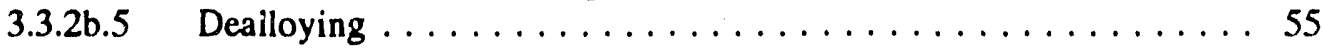

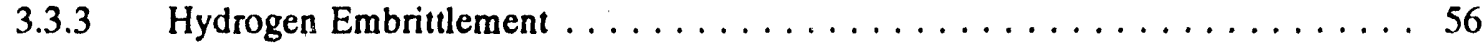

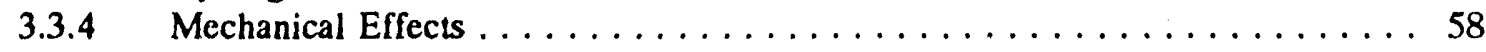

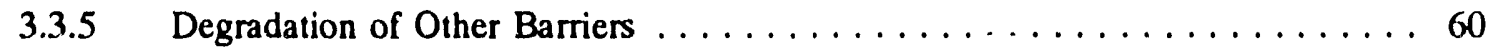

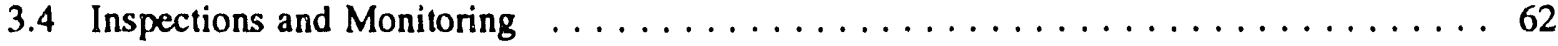

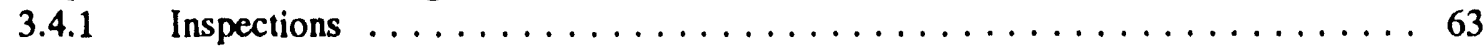

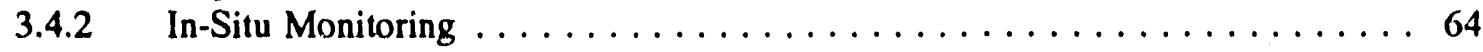

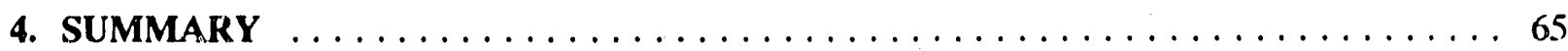


APPENDICES

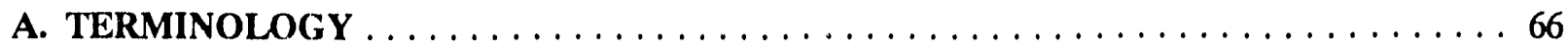

B. U, S. CODE OF FEDERAL REgULATIONS, 10 CFR PART 60, "DISPOSAL OF HIGH-LEVEL RADIOACTIVE WASTES IN GEOLOGIC REPOSITORIES ${ }^{\prime} \ldots \ldots$. . . 69

vi 


\section{EXECUTIVE SUMMARY}

Performance-related U.S. Nuclear Regulatory Commission (NRC) regulations for high-level waste (HLW) include 10 CFR 60.112 on repository system performance, which implements the U.S. Environmental Protection Agency (EPA) requirements related to the releases of HLW. The waste package is a subsystem of the overall repository system. NRC performance requirements for this subsystem are given in 10 CFR 60.113 , which prescribes that containment of HLW be "substantially complete" during the period when radiation and thermal conditions in the engineered barrier system are dominated by fission product decay. The minimum period of containment is specified as 300 to 1000 years after permanent closure of the geologic repository. The waste package is required to prevent transfer of radionuclides beyond the boundary of the waste package, during this decay period. It should be noted that a container that is more durable than that required for the containment period could be used in satisfying another requirement related to the rate of release of radionuclides; controlled release subsequent to the containment period is specified. Thus, a more durable container could assist in controlling any calculated release of radionuclides. The meaning of the term "substantially complete containment" in this context is addressed in a series of three reports. As the first report in this series, this report is a compendium of technical information and considerations that must be addressed in arguments for satisfying containment requirements of HLW. For the purposes of this report, it is assumed that a waste container, as part of the waste package, provides a significant part of the containment function.

Various types of uncertainties are associated with most of the technical poinis atidressed in this report. For example, the rate of corrosion or the form of corrosion may not be known in an absolute sense over extended times for which containment is required under $10 \mathrm{CFR} 60.113$. The technical challenge is to minimize these uncertainties and to furnish predictive models that provide the reasonable assurance required to comply with the regulation. The knowledge and understanding of the waste package, especially the solutions to technical issues of the types addressed in this report, are expected both to govern the accuracy of predictions of waste-package performance and to govern, thereby, compliance with any NRC requirements for containment.

In the second report, state-of-the-art techniques for uncertainty evaluations are presented. These techniques can be used to form a technical basis for the development of critcria for making containment evaluations that are easy to interpret without ambiguity. For example, given the uncertainties of the types discussed in the first report, the methods described in the second one can be used to evaluate and, in some cases, to quantify the uncertainties. The aim is to permit a quantitative assessment of the probability of waste-package failures as a function of time. The third report, on the basis of the information provided in the first two, develops recommendations for resolving the regulatory uncertainty in 10 CFR 60.113.

Various technical questions must be answered in making a defensible argument that containment of HLW within a waste package will be "substantially complete." In the application of materials science and engineering, a unique problem that is posed by an HLW repository centers on the long duration of the minimum containment period, the extremely large number of waste packages in the repository, and the moderately elevated temperatures. Under proposed U.S. designs, temperatures are expected to be moderately elevated, up to about $250^{\circ} \mathrm{C}$. Waste-package designs that are likely to be advanced are expected to involve the use of a primary container and perhaps other secondary containers and barriers to the release of radionuciicies. Containers are likely to be made of metals or metal alloys, but ceramics, modern composites, or other combinations of materials and barriers may also be suitable alternatives. In the examples cited in this report, strong emphasis has been given to metal alloys, as, to date, thesc are the materials primarily selected, in this country and abroad, as candidate materials for containers.

The requirements of 10 CFR 60.113 stipulate that, for a specified period ranging from 300 to 1000 years, containment shall be "substantially complete." In addition, it is required that the release of any 
radionuclide from the engineered barrier system following the containment period shall not exceed a specified rate. As a result, knowledge of the behavior of waste package containers for periods well beyond the minimum containment period will be necessary. This expectation endures because, at the longer times, some credit for containment or controlled release may be desired in demonstrating that the requirements for controlled release have been met. Thus, the service period of interest may extend for thousands of years. Although it is known that manmade artifacts have survived many centuries in hostile environments, mankind has never attempted to gain experience with or develop analogues for this unique problem. The duration of the required service period is much longer, by orders of magnitude, than the times over which laboratory experiments can be conducted. Hence, there is a need for the development of methods for the prediction of service behavior over these long periods.

In this report, the principal, or high-order, technical considerations related to the materials, the environments, and the interactions between them are described.

The major areas of environmental interest most likely to influence the response of HLW containers are covered in Section 3.1. It should be noted that the environment that a container will experience consists not only of the external environment of the natural repository, but also of the contents of the container itself. In addition, the external environment is modified by the combined effects of radiation and heat as a result of the radioactive decay of the nuclear waste in the container. The external environmental factors are discussed in Section 3.1.1 to 3.1.4 under four headings: geochemistry, hydrology and climatology, geology, and volcanic and seismic hazards. Chemical and mechanical factors are extremely important in the evaluation of the performance of a waste package. They are discussed under the headings noted above in Section 3.1, also taking into consideration the synergisic effects of radiation, radiolysis products, corrosion products, and microbial activity, as described in some detail in Sections 3.1.5 and 3.1.6.

In Section 3.2, the discussion is centered on the material requirements for waste-package components. Predictions based on the results of studies of the interactions between materials and the environments are based on an assumption that the materials in a waste package will be very similar to the materials being studied, and so controls on the quality of eventual waste-package components are crucial to making meaningful predictions. As presented in Section 3.2.1, an effective quality control program will ensure that the materials used in a waste package 1) meet all specified requirements, 2) are fabricated using qualified personnel and approved processes, and 3) are free of any significant damage due to transportation and emplacement.

Materials are characterived by their physical and mechanical properties and by their behavior in the presence of a given environment which, in turn, may affect those properties. In order to predict behavior for extended times, the relations between material properties and the environment, including factors such as temperature, radiation, etc., must be known. The complexity of the problem is compounded by the effects of processes used for fabrication or repair of HLW containers, as discussed in Section 3.2.4. These processes can strongly influence materials properties, leading to complex behaviors under the various environmental conditions that will be encountered over the service life of the containers. Uncertainties on materials behavior can be decreased by the use of materials specifications, fabrication process specifications, and appropriate materials characterizations. These topics are reviewed here, and it is emphasized that materials characterization for the waste-package components requires a demonstrated understanding of factors that might affect long-term service behavior. These factors include variations in characteristics such as chemical conposition, state of stress, microstructure, fabrication or production history, and thermodynamic phase equilibria.

From the presentation of technical considerations given in this report, it becomes clear that uncertainties associated with each of the considerations may be significant, and that an extended service 
life can be assured only if these uncertainties are understood and minimized. These assurances may be obtained through scientific understanding, the application of good engineering practices, and implementation of quality control procedures that render assurances that the environment is within the expected range for which waste containers were designed, and that the containers and the materials from which they were fabricated are within design specifications. In addition, inspections have important roles throughout the waste disposal process, from the time that materials for use in a waste package are received to the time of emplacement into a repository. Containers, environments, and their interactions - can be monitored after emplacement, as part of a process for confirming the adequacy of service-life predictions. Selective monitoring may be continued throughout the preclosure period.

Processes by which materials can be altered are numerous, and in this report, many of them are discussed briefly to highlight the importance of understanding the behavior that may lead to degradation. It is imperative that all potential failure modes that could lead to accelerated rates of degradation of a container be exhaustively studied. In this report, a more extensive coverage is given to the topics of degradation modes expected for metallic materials. Most of localized corrosion processes as well as other forms of metal degradation or failure, such as hydrogen embrittlement and stress corrosion cracking, are discussed in Section 3.3. This is done to emphasize the need to ensure that failure will not occur by any of the mechanisms that can lead to a localization or an acceleration of degradation, as, for example, by pitting and crevice corrosion, stress corrosion cracking, hydrogen embrittlement (or damage), dealloying, or microbial corrosion. Mechanical effects that can lead to changes in the state of stress in a container may also be important to service life, as noted in Section 3.3.4. The stress state may be affected, for example, by external pressure (hydrostatic or lithostatic), by internal pressure from reactions within the waste form, by corrosion products, or by thermal cycling brought about from the effects of water dripping onto a hot container.

The current NRC requirements mandate that HLW must be retrievable on a reasonable schedule beginning up to 50 years after waste emplacement commences at an HLW repository. Consequences of errors in evaluation on the durability of a waste package can be rectified, by appropriate modifications/repair of the waste package, during this retrievability period, and before any potential hazard can become a threat to public safety. As needed and after emplacement, the repository conditions and the responses of the components of a waste package to those conditions can be monitored to increase assurance that the behavior is consistent with the understanding used in the design of the waste-package subsystem. Accordingly, monitoring in-situ can be done during the preclosure period, as discussed in Section 3.4. In addition, during this period, laboratory and in-situ tests can be conducted to more firmly resolve questions related to the scientific principles and engineering judgments that were used in the repository design. 


\section{ACKNOWLEDGMENTS}

The authors wish to acknowledge the members of the Center for Nuclear Waste Regulatory Analyses (CNWRA) technical and management staff for their comments and review of various sections of this report. Contributions from the Geologic Setting Group (Michael F. Miklas, Ronald T. Green, and William M. Murphy), the Engineered Barrier Systems Group (Emil Tschoepe, III, Gustavo A. Cragnolino, and Narasi Sridhar), and the Itasca Consulting Group (Loren Lorig) are especially recognized. The authors also express their appreciation to the U.S. Nuclear Regulatory Commission staff (especially Joseph $O$. Bunting, Jerome R. Pearring, and Richard Weller) for many helpful reviews during the preparation of this report. Members of the editorial, drafting, and word processing sections (Shirley Heller, Wanda Brandon, Bonnie Garcia, Ellen Krause, Alana Woods, and Curtis Gray) are also thanked for their assistance in preparing this report. 


\section{INTRODUCTION}

The Code of Federal Regulations (CFR), Title 10, Chapter I, contains regulations set forth by actions of the Nuclear Regulatory Commission (NRC), and in Part 60 of that chapter, the "Disposal of High-Level Radioactive Wastes in Geologic Repositories" is addressed. Two paragraphs in Part 60 are the principal focus of the current work on the containment of high-level radioactive waste (HLW). They are $10 \mathrm{CFR}$ 60.112, "Overall system performance objective for the geologic repository after permanent closure" and 10 CFR 60.113, "Performance of particular barriers after permanent closure." In $10 \mathrm{CFR}$ 60.112 , the performance requirements for the overall geologic repository system are provided. In $10 \mathrm{CFR}$ 60.113, the performance requirements for the engineered barrier system and geologic setting subsystems of the repository system are given.

As noted in the following paragraphs, the performance requirements for the engineered barrier system consist of two parts: (1) a "containment" requirement for HLW packages, and (2) a radionuclide release rate limit from the engineered barrior system. Taken together, these two parts are intended to control the release of radioactive materials to the geologic setting and to add confidence that the overall system performance objectives for the repository (i.e., 10 CFR 60.112) will be met.

The performance requirements for the engineered barrier system, as contained in 10 CFR 60.113, specify that:

(i) "The engineered barrier system shall be designed so that assuming anticipated processes and events: (A) Containment of HLW will be substantially complete during the period when radiation and thermal conditions in the engineered harrier system are dominated by fission product decay; and (B) any release of radionuclides from the engineered barrier system shall be a gradual process which results in small fractional releases to the geologic setting over long times. ..."

(ii) "In satisfying the preceding requirements, the engineered barrier system shall be designed, assuming anticipated processes and events, so that:

(A) Containment of HLW within the waste packages will be substantially complete for a period to be determined by the Commission taking into account the factors specified in 60.113 (b) provided, that such period shall be not less than 300 years nor more than 1000 years after permanent closure of the geologic repository; and

(B) The relcase rate of any radionuclide from the engineered barrier sysiem following the containment period shall not exceed one part in 100,000 per year of the inventory of that radionuclide calculated to be present at 1000 years following permanent closure, or such other fraction of the inventory as may be approved or specified by the Commission; provided that this requirement does not apply to any radionuclide which is released at a rate less than $0.1 \%$ of the calculated total release rate limit. The calculated total release rate limit shall be taken to be one part in 100,000 per year of the inventory of radioactive waste, originally emplaced in the underground facility, that remains after 1000 years of radioactive decay."

Although the requirement in the rule for limited release from the engineered barrier system in the post-containment period is clearly stated in numerical terms, the companion or associated requirement for "substantially complete containment" during the containment period is qualitative and subject to interpretation. The Center for Nuclear Watse Regulatory Analyses (CNWKA) has developed a systematic approach for evaluating and analyzing the regulations affecting the HLW program. The rationale for the systems approach is to enable the analyst to identify, among other things, specific interrelated regulatory requirements, "what" must be proven to demonstrate compliance with these regulations, and "how" one 
might demonstrate compliance with the requirements. As part of this process, uncertainties in the regulations are also evaluated and potential uncertainty resolution strategies explored. Preliminary analysis of regulations related to the performance of waste packages within the engineered barrier system indicates that there is uncertainty with respect to these requirements, and the CNWRA is assessing various uncertainty resolution strategies. This report supports an initial effort to assess the technical feasibility of the strategy for eliminating the noted regulatory uncertainty.

One reason why a rapid resolution of the meaning of this rule has not occurred is that this problem of containment for extraordinary periods of time is being confronted in a scientifically defensible way for the first time in the history of mankind.

Three factors make "quantification" difficult; and these, listed as follows, will require the judicious application of advanced and relevant technologies.

\section{(1) Length of time}

The length of time specified in the regulation exceeds the times commonly required in engineering design and it is especially long for containment problems. For example, the design life of pressure vessels can range from 30 to $\mathbf{4 0}$ years for nuclear reactors, to as short as a few hours or days for rocket motor cases.

\section{(2) Size scale}

The expected number of containers ranges from about 20,000 to as high as 80,000 , depending on the waste package and emplacement design. This extremely large number of containers implies that scaling up from laboratory and prototype tests to the size of the repository is an almost unique endeavor. As an example, failures such as those experienced in the Alaska pipeline illustrate the nature of the problems to be confronted in engineered systems of a size equivalent to the repository [Refs. 1,2$]^{\circ}$.

\section{(3) Inaccessibility}

In a closed repository that is not subject to active institutional controls, a waste package will be inaccessible for inspection during the majority of the service life, which is up to thousands of years. After the repository has been closed and sealed, the reasnnable assurance of containment must come from a very high level of confidence in a scientific understanding of the effects of time and the environment on a repository system composed of an extremely large number of waste packages.

Pursuant to implementing the recommendation in SECY-88-285 [Ref. 3], regarding clarification of the regulatory requirement for "substantially complete containment," the NRC Division of High-Level Waste Management Engineering Branch prepared a proposed scope for a possible rulemaking effort [Ref. 4] and a policy options paper [Ref. 5]. Among the recommendations in the policy options paper was the recommendation to pursue the establishment of criteria that would focus the U.S. Department of Energy's (DOE's) designers on achieving "containment, "rather than an acceptable release rate during the containment period specified in 10 CFR Part 60. This option was viewed as being more consistent with the rationale contained in the Statement of Considerations (NUREG-0804) [Ref. 6] supporting 10 CFR Part 60 [Ref. 7].

\footnotetext{
- Brackets are used to facilitate computer search of references.
} 
A number of other alternatives for clarification of the intent of the 10 CFR Part 60 requirement were examined. Rulemaking was recommended as the appropriate alternative. This recommendation was based on the perceived importance of having a clarification that would endure over the relatively long time period of the repository licensing process and not be subject to change based on subsequent personal interpretations. The policy options paper recommended the establishment of quantifiable criteria to clarify the qualitative nature of the "substantially complete containment" requirement. In addition, it was recommended that an assessment should be conducted before rulemaking. In that assessment, the technical feasibility of establishing and demonstrating compliance, using quantifiable criteria, would be explored. After NRC management approval, the CNWRA was contracted to conduct the technical feasibility assessment.

In response to this contractual direction, the CNWRA is examining the feasibility of this option. On the basis of information gathered during this feasibility study, the CNWRA will make recommendations related to the technical feasibility of rulemaking as a vehicle for clarification of the intent of 10 CFR Part 60 on the question of "substantially complete containment."

As a part of this work, the CNWRA has developed three background technical reports to provide a common technical basis from which a rule can be developed, if appropriate. The purposes of the first of these reports, which is the one presented here, are to present and describe the technical topics that must be considered in assessments of the long-term performance of the waste package. The second report describes the methodology for assessing "how well" the various technical considerations can be evaluated in the face of known and, at times, unknown uncertainties. The methods described in the second report can be used to quantify various types of uncertainties and permit a quantitative assessment of the probabilities of :vaste-package failures in a given time. The thircl companion report, on the basis of the information provided in the first two reports, develops recommendations for the resolution of the issue of "substantially complete containment" of HLW within the waste package.

\section{References}

1. R. Bloomberg, "Alaska Starts Repairing Miles of Corroded Pipes," Erigineering News Record, 224 (10), March 8, 1990.

2. R. P. Reed and H. I. McHenry, and M. B. Kasen, "A Fracture Mechanics Evaluation of Girth Pipeline Weldments," WRC Bul. 245, January 1979.

3. W. C. Parler and V. Stello, Jr., "Regulatory Strategy and Schedules for the High-Level Waste Repository Program, U.S. NRC Policy Issue (Information)," SECY-88-285, October 5, 1988.

4. J. O. Bunting, "Technical Policy Options to Minimize the Regulatory Uncertainty Regarding Substantially Complete Containment," Draft Report, March 20, 1989.

5. J. O. Bunting, R. A. Weller, C. Peterson, and C. Interrante, "Scoping Paper for Proposed Rulemaking to Minimize the Uncertainty Regarding the Regulatory Requirement for Substantially Complete Containment," Draft Report, Revision 1, March 28, 1989.

6. U.S. Nuclear Regulatory Commission, Staff Analysis of Public Comments on Proposed Rule 10 CFR Part 60, "Disposal of High-Level Radioactive Wastes in Geologic Repositories," NUREG-0804, December 1983. 
7. U.S. Code of Federal Regulations, "Disposal of High-Level Radioactive Waste in Geologic Repositories," Part 60, Chapter I, Title 10, "Energy." (Attached as Appendix B to this report.)

4 


\section{APPROACH TO REDUCING AMBIGUITY RELATED TO SUBSTANTIALLY COMPLETE CONTAINMENT (SCC)}

A part of the systematic analysis process is a grouping of 10 CFR Part 60 requirements into inaividual subject areas called Regulatory Requirements (RRs). The containment regulation is identified as RR1002, entitled "Containment Performance after Permanent Closure." It includes all the text cited in 10 CFR $60.113(a)(1)(a)(A)$ and parts of 10 CFR Part 60 related to the waste package design. The preliminary analysis performed en RR1002 included the development of a sct of specific statements of "what must be proven" called the Regulatory Elements of Proof (REOP) and a logical hierarchy of REOP interrelationships. To evaluate each REOP, Technical Review Components (TRCs) were identified. The TRCs are the technical material required to demonstrate or determine compliance with each REOP. To assess compliance with each TRC, a Compliance Determination Method (CDM) is required. CDMs provide the answer to "how" une attempts to satisfy the "whats" expressed in the various TRCs. The CDM involves an approacn or a methodology based on technical argumerits or reasons to establish that the TRC has been satisfactorily addressed. As part of a CDM development strategy there will be a need for technical models, data, and laboratory and field analyses. These are classified as Information Requirements (IRs).

In the case of RR1002, the preliminary analysis of the RR indicates that the words "substantially complete containment" create both a regulatory and a technical uncertainty. The uncertainty affects several REOPs, TRCs, and IRs. As a result, a fundamental investigation is required to develop an understanding of the sources of this uncertainty. An apprcach has been formulated, where is is assumed that hy first addressing the iechnical considerations of RR1002, it will be possible to resolve the technical uncertainty and consequently result in minimizing the regulatory uncertainty.

This report identifies technical considerations that would have to be addressed in the assessment of the degree of HLW containment or the establishment that HLW containment is satisfied within a waste package in a geolc gic repository. In SECY-88-285, "Regulatory Strategy and Schedules for High-Level Waste Repository Program," NRC listed "Further Amplification of the Meaning of the Phrase 'Substantially Complete Contairment'" as a planred potential rulemaking.

A key factor related to the performance of a waste package in a repository is the very long service life required. This seivice life exceeds the duration of even the lengthiest possible laboratory tests and/or in-situ confirmation munitoring, which could approach 50 years. For this reason, arguments of compliance related to HLW containment will be both based on well-established scientific and engineering principles and supported by analyses pertaining to the technical considerations addressed in this report. The tect:nical points discussed here will cover many of those needed to demonstrate that new quantitative requirements in HLW regulations have been met, and that the new requirements will eliminate the uncertainty associated with the current regulation.

The technical considerations in this report relate to our understanding of factors governing long-term behavior of materials in a specific environment. These have been broadly grouped into four categuries for discussion; that is, environment, materials and fabrication, degradation processes, and inspections and monioring. Figure 1 shows the various technical topics that relate to each of the categories and are discussed under that category. In a number of cases, however, the technical topic given in one category may apply to one or more categories. The discussion of such topics has not been repeated. In this document, the topics are introduced and discussed without attempting to cover all possible techni:al aspects related to each of them. 
TECHUICAC COUSIDERATIONB FOR

EVRIUATIMG "BUBSTANTIATI COMPLES:

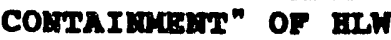

\section{ENVIRONMENT}

- Geochemistry

- Wuter chernistry

- pH \& Eh

- Types/concentrations

of leached minerals

- Container corrosion

products

- Backfill

- Conteiner fallure

effects

- Hydrology and

Climatology

- Groundwater

quantity/movement

- Temperature

- Pressure

- Rainfall

- Flooding

- Geology

- Host rock

- Porosity

- Saturation

- Effect of thermai

cycles

- Volcanic \& Seismic

Hazards

- Volcanotectonics

- Seismicity

effects

- Radiation \&

Radiolysis

- Gamma ndiation

effects

- Radiolysis

compounds

- Microbial Environments

and Effects

- Environmental

changes

- Radionuclide

migration

- Contuiner Internals

- Waste form mix

- Fission products

- Radion uclides

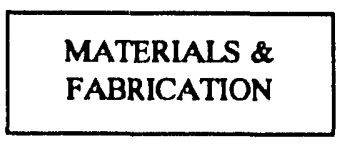

- Quality Control

Plan

- Malerials

Specifications

- Chemical composition

- Microstructure

- Mechanical

properties

- Waste forms

- Materials

Characterization

- Chemical composidon

- Surface propertics

- Bulk properties

- Mechauical properties

- Corrosion resistance

- Fabrication Process

Specificatioas

- Container

- Welding

- Surface finish

- Heat treatment

- Repair procedares

- Metal Stability

- Base material

- Weldments

- Radiation effects

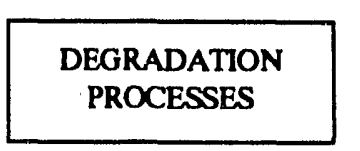

\section{- Gas-Metal \\ Intenctions/ \\ Oxidation}

- Aqueons Corrosion

- Uniform corrosion

- Localized corrosion

- galvanic

- pittiag

- crevice

- stress corrosion

cracking

- dealloying

- Microbial Corrosion

- Hydrogea

Embrittlement

- Solid solation

- Hydrides

- Reduction of

oxide

- Mechanical Effects

- Hydrostatic

pressure

- Lithostatic

pressure

- Waste form (waste

package contents)

- Thermal-fatigue

- Creep-ruptere

- Degradation of Other

Barriers

- Galvanic

- Fission gases

- Radionuclides

- Trassport/Adsorption

Berriers
INSPECTIONS \& MONITORING

- Inspections

- Visual

- Sampling

- Non-Destructive Examination

- Destructive testing

- In-Situ Monitoring

- Preclosure

- Postclosure

Figure 1. Technical considerations for evaluating "substantially complete containment" of high-level radioactive waste within the waste package. 


\section{TECHNICAL CONSIDERATIONS}

Various technical points must be considered to establish the extent to which containment is complete. Examples of these are given in this report. The technical points discussed here represent some of the key factors that will have to be considered in a technical argument on the containment capabilities of a waste package. These are briefly introduced under (1) through (4) below and then discussed in more detail in sections 3.1 through 3.4 .

The format chosen for discussion provides a brief statement oi a definition of the subject of the mini-chapter, possible concerns in that area as they relate to the ability of the waste package in providing containment for its radioactive inventory (vitrified waste forms or spent light water reactor (LWR)--both boiling water reactor (BWR) and pressurized water reactor (PWR)--fuels), and the basis or justification for those concerns, including some examples, followed by a few general references to provide additional reading material/information on the subject. The mini-chapters have been constrained by the format to approximately two pages, with bibliographic references limited to ten. This format keeps the discussion on the various topics at the higher-order. The examples provided in the report are for illustrative purposes, and by no means cover all possible situations cnvisaged in a HLW repository.

\section{(1) Environment}

As all components of a waste package may be altered in time within the repository environment, the characterization of the environment becomes an important element in any proof that regulatory requirements have been met. For example, for a container of nuclear waste, two types of environmental effects may be important, those from within the container and those from without. The internal environment, characterized by continued fission reactions of the waste, yields heat and radiation. The heat generated by the waste will increase the ambient temperature and thereby affect the conditions of exposure for the components of the waste package. All these results of fission reactions should be considered to be part of the environment.

In the external environment, both chemical and mechanical influences will be important to the performance of a waste package. The principal chemical concerns are the amount of available oxygen and water as well as the salinity of the water, although other chemical components may also be important to waste package performance. The principal mechanical concerns are the levels of stress that arise from environmental influences, such as those from tectonic and seismic activities. These various external influences are discussed in this report under four headings: geochemistry, hydrology and temporal climatology, geology, and tectonics and seismic hazards. A more complete description of the environment would include both the internal factors discussid above, as well as the characteristics of the individual waste-package emplacement sites within the repository.

\section{(2) Materials and Fabrication}

Waste-package components, in addition to vitrified waste form in a pour canister or spent $L W R$ fuel rods or assemblies, might include a container (metallic, ceramic, or composite material), a diffusion barrier (such as bentonite clay), and a liner in a waste-package borehole. A principal objective is to contain radionuclides within the waste package so that they do not begin to migrate into the rock comprising the walls of the borehole within the required containment period. Materials characterization for the wastepackage components requires a demonstrated understanding of factors that might affect long-term service behavior. These factors include variations in characieristics such as chemical composition, state of stress, microstructure, fabrication or production history, and thermodynamic phase equilibria. 


\section{(3) Degradation Processes}

Long-term exposure of materials in a repository could result in profound alterations in materials during the service life. The presence of HLW inventory will lead to elevated temperatures and furnish high levels of radiation. The host media for the repository can be the sources of oxygen, water, and other species that can be aggressive in altering the nature of the materials used for containment of the waste. Thus, various interactions may be expected from gaseous or aqueous media that contact these materials. For metallic containers, for example, various forms of corrosion that result from interactions with water and oxygen are important, as are the effects of hydrogen, which may result from radiolysis of water and vapor or galvanic coupling with borehole liner or container support structures. The environment may produce hydrostatic or lithostatic pressure, which may alter the stress state in waste package components. Unusual seismic events could lead to high dynamic loads. Radiation will change the environment and create species with the potential for accelerated degradation of the waste package components. If microbial species are present, they, too, have potential for interactions with the waste package materials. These interactions between the environment and the waste package components, including joints, seals and welds, must be understood and considered when determining the service life of the waste package. The iniernal environment of a container also may play a significant role in promoting failure from within.

\section{(4) Inspections and Monitoring}

Materials and product specifications for each component of the waste package are necessary to ensure that materials of construction and intermediate and final products conform to appropriate quality standards. Fabrication of various waste package components require control through use of qualified personnel and equipment, procedures, and in-process product examinations. Inspection criteria are required to determine the acceptability of fabricated components for repository emplacement. Finally, in-situ monitoring should be considered for evaluating the performance of the waste package up to the time of permanent closure. 


\subsection{Environment}

The environment in the repository, both at the time of emplacement of the HLW container and over the hundreds to thousands of years after the repository is sealed, will affect the performance of the waste package. More specifically, the term "performance" here means the ability of the waste package to provide the required level of containment for the radioactive waste inside the container. The waste is expected to be both vitrified waste in the form of glass poured in a stainless steel or other metal pourcanister and spent LWR uranium dioxide fuel contained in Zircaloy or stainless steel cladding.

The major areas of environmental interest most likely to influence the response of HLW containers fall broadly into the following seven classifications: (1) Geochemistry (water chemistry, pH, Eh, rock chemistry, and trapped, dissolved, or circulating gases); (2) Hydrology and Climatology (temperature, pressure, rainfall, ground-water flux, changes in th: water table, and flooding); (3) Geology (host rock effects of variables like thermal cycles, radiation field, and radiolysis products on the host rock); (4) Vcicanic and Seismic Hazards (volcanotectonics and seismicity); (5) Radiation and Radiolysis; (6) Microbial Effects; and (7) Container Internals. Although the above-mentioned seven areas are discussed separately in this report, the synergistic effects of two or more areas could lead to more severe environmental effects on the HLW container and other components of the waste package than consideration of the invironmental factors separately. An example could be the possible development/evolution of new strains of microorganisms due to the synergistic effects of radiation, radiolysis products, waste package corrosion products, and leached minerals from the surrounding geology. These new strains of microorganisms could change the mechanism or accelerate the corrosion of metallic containers and/or aid in the migration of radionuclides to the accessible environments. Such coupled effects are of considerable concern and, therefore, must be studied well. These seven areas, stated above, are discussed next. 


\subsubsection{Geochemistry}

\section{Statement}

Near-field geochemistry is likely to have a major influence on the degradation modes of HLW package componerits.

\section{Concern}

Inadequate understanding of the existing geochemistry of a repository and of the changes that could occur over time could lead to inappropriate design of the waste package and of the laboratory experiments used to obtain data to support the design of the individual components. The results of such experiments, if used for modeling the waste package behavior in a repository environment, could provide inaccurate predictions of the time for which the waste package could provide he required level of containment for its radioactive contents.

Basis

Many variables could affect the behavior of metallic containers in a repository environment. Molecular and ionic species dissolved in water may have signiiicant effects on the corrosive action of water. For example, high levels of chloride are detrimental to common types of stainless steels, but may be less deleterious tc copper and copper-based alloys. On the other hand, sulfates, sulfites, other sulfur compounds, and nitric acid could be much more harmful to copper and copper-based alloys than to stainless steels. The $\mathrm{pH}$ and red $\mathrm{x}$ potential of the environment affects corrosion rates and mechanisms. Carbonate, sulfide, and other species occurring in the aqueous phase can form stable compounds with container materials.

Factors that influence the nature and concentration of constituents dissolved in groundwater include the mineralogy of the rock in contact with the water, the composition of the vapor phase, the temperature and pressure at which water-rock interaction takes place, the duration of the interaction, and the ratio of rock-surface area to water volume. The last two par' cuiers are most important for interpretation of kinetically controlled dissolution and precipitation reactions. Knowledge of water chemistry is necessary to establish the corrosion behavior of the waste package. Besides naturally occurring species, the effects of species leached from the repository materials, and the radiolysis compounds produced by the $\mathrm{mma}$ radiation emanating from the HLW containers could change the gexhemistry substantially. Release of metal iuns from other components of the engineered barrier system, such as container- and dolly-support plate, borehole iner, and borehole seal cap, could add further complexity to the chemistry of the liquids present. Other variables/unknowns that could influence the geochemistry include (1) microbial and bacterial activities, (2) evaporation and refluxing cycles associated with the heat pipe effect that might occur (which could concentrate the amount of certain salts in the ingress water), and (3) variations in solubility or reactivity of phases in the repository geology, due to gamma radiation, or elevated temperatures, or variations in $\mathrm{pH}$ or oxidation state.

The nature of groundwater and/or ground-gas flux and llow also needs to be considered. Low matrix flow rates result in long contact times between rock and water, or between container and water. Flow through fractures may be slow or rapid, depending on the fracticie aperture and the water flux. Gas flow in partially saturated media could lead to important fluxes of moisture or volatile species that affect groundwater properties such as oxidation state and $\mathrm{pH}$. Vapor-liquid phase relations as a function of temperature, coupled with the hydrologic behavior of the system and pressure, may affect the quantity and composition of groundwater in contact with the containers. 
Tests must be conducted to cover the range of possible conditions to determine the resultant or possible changes in water chemistry for different contact times, rock-to-water ratios, temperatures, and rock chemistry. Development of models to accurately predict changes in the geochemistry of the repository are also netded.

\section{Bibliography}

1. Commission on Physical Sciences, Mathematics, and Resources, Waste Isolation Systems Panel Board on Radioactive Waste Management, A Study of the Isolation System for Geologic Disposal of Radioactive Wastes, National Academy Press, Washington, D.C., 1983.

2. J. A. Apps, "Geochemistry Research Planning for the Underground Storage of High-Level Nuclear Waste," Lawrence Berkeley Laboratory, Division of Earth Sciences, Report No. LBL-17745, September 1983. 


\subsubsection{Hydrology and Climatology}

\section{Statement}

Hydrologic and climatic changes could affect the repository environment, which could lead to changes in the waste-package materials degradation modes and/or the kinetics of degradation.

\section{Concern}

Inadequate characterization of the existing hydrological conditions at the beginning of the repository 'operation and of the anticipated climatic and hydrologic changes could lead to inaccurate predictions of the ability of the waste package to provide containment for the radionuclides.

Basis

Hydrology affects transport rates, which, in turn, affect chemical reaction rates. The kinetics of many chemical reactions that are likely to lead to degradation of the materials (metallic and nonmetallic) depend on temperature, pressure and amount, mobility, and chemical nature of water. The geological environment is expected to be a fractured porous medium with water vapor present in the fractures during the period when the waste material is emanating significant heat. By virtue of the heat-pipe effect, if present, liquid water should be driven away from the heat-generating waste, leaving only water vapor in the near-field environment of the waste package. The level of vapor- and liquid-water saturation in the near-field environment can be affected by changes in hydrology and climate. Climatic changes can result in changes in rainfall, evapotranspiration, infiltration rates, and the global or regional saturation level of the host medium. Additionally, for locations where the host medium is a fractured, porous rock, the hydraulic conductivity of fractures would increase as the saturation level of the rock increases. Consequently, infiltration rates could be greatly affected. Greater infiltration rates could increase the vapor- and liquid-water levels near the waste package and, therefore, affect the kinetics of the chemical reactions in the near-field environment of the container and thus the expected corrosion rates of the waste package. The nature of the engineered overpack can affect the phenomena of flow and transport near the waste package, particularly in conjunction with a heat pipe. The thermal and hydrogeologic characteristics of the overpack can either impede or enhance the flow of heat and/or liquid to or away from the waste package during the period of time when the waste generates sufficient heat to cause a heat pipe to occur.

In addition to changes in the amount of water vapor and liquid water present in the environment near a waste package, changes in water chemistry, temperature, and mobility can be expected to occur as a result of hydrogeological and climatic changes. These variations in water chemistry, temperature, and mobility can also affect the nature of corrosion of a container in a repository setting. Some of these variables could change very little with time, while others could change considerably due to major climatological and/or hydrological shifts over the many hundreds to thousands of years of the wastepackage life in a geologic repository. Therefore, the ability to predict the degradation of the waste package due to vapor- and aqueous-phase corrosion will depend on the accuracy with which the hydrologic and climatologic changes that are likely to affect the repository are determined.

Great uncertainty may exist in some of the predictions that can be made in the climatologic/hydrologic realm. Effects of other repository-specific variables such as the level of saturation as it affects vapor-phase circulation, and the resulting effects on the degradation of the container materials, need to be understood. If an initially unsaturated repository becomes saturated during the period when the waste package is required to provide complete containment of the radionuclides, or if an initially saturated repository becomes unsaturated with time, significant effects on container integrity may become evident. 
1. K. Preuss, and J. S. Y. Wang, "TOUGH: A Numerical Model for Nonisothermal Unsaturated Flow to Study Waste Canister Heating Effects," Mat. Res. Soc. Symp. Proc. 26 , 1984.

2. U. S. Depart dent of Energy, "Site Characterization Plan," DOE/RW-0199, 1988.

3. H. H. Uhlig, Corrosion Handbook, J. Wiley and Sons, Inc., New York, New York, 1948.

4. H. A. Wollenberg, J. Wang, and G. Korbin, "An Appraisal of Nuclear Waste Isolation in the Vadose Zone in Arid and Semi-Arid Regions," NUREG/CR-3158, 1983. 


\subsubsection{Geology}

Statement

The geology of the repository is likely to have a direct influence on the waste package degradation kinetics or mechanisms in a repository.

\section{Concern}

The geology of the repository can influence various factors related to waste-package performance: (1) the water flow paths and rates, (2) the existence and multiplication of certain types of microorganisms and bacteria that could be detrimental to metal corrosion, (3) conduction of heat generated through the radioactive decay of the canister contents (spent fuel and vitrified waste), (4) the chemical nature of the leached species as a result of radiation-induced phase transformation of minerals in the repository geology, and (5) the build-up of gas pressure due to low permeability of the rocks.

Inadequate understanding of one or more of the important variables of the geological setting could lead to incorrect modeling of the influence of the geology on the degradation behavior of the waste package components. For example, water-rock interaction affects water chemistry, which, in turn, could produce reducing or oxidizing conditions, changes in $\mathrm{pH}$, types and amounts of chemical species detrimental to the materials of construction of the waste package, and other effects that may lead to accelerated degradation of the waste package. Such effects need to be identified and understood.

\section{Basis}

The geology of a repository influences to a large extent what, how much, and for how long a certain environment will exist around the container, and how it may change with time. A deep geological repository can in one simplistic way be considered as a semi-closed system. The input to this system, the output from the system, and what essentially stays in all the time will all influence the behavior of the waste package.

The geology of the selected repository site should exhibit favorable characteristics that would provide an additional level of barrier against the migration of radionuclides from the waste package. For example, the desirability of emplacing waste in an unsaturated environment is high. Waste packages in an unsaturated zone would not routinely be submerged in water, although high humidity in the surroundings might prevail. In a saturated repository, the flux of groundwater to and from the containers will be influenced by the heat load imposed by the waste package on the host geology. Rapid heating of the host geology could lead to increased fracturing and/or increase in fracture aperture, which would change groundwater flux. Likewise, geochemical changes dependent on time-of-contact of migrating groundwater with the HLW packages would be influenced by changes in the groundwater flux.

In the early stages of the repository, when temperatures are highest and the heat load the greatest, there will be the dampening effect of the conversion of near-field liquid water to water vapor and its attendant heat-pipe. The thermal conductivity of the host rock is dependent upon factors such as porosity, mineral composition, density, and saturation level of the gas in the pore spaces. The bulk thermal conductivity of the host rock will control the maximum temperature rise of the geologic setting for a given waste form and thermal loading. If gas permieability is low, with increasing heat, the pressures in the pore space in the host geology could cause a rise in pressure around the waste packages. This, in turn, could increase the rate of chemical interactions between the surrounding liquid or vapor and waste packages. 
Transmission of heat by convection and conduction from the waste package through an air gap to the borehole is dependent on the flow and characteristics of air around the waste package. In addition to convective air currents in the air gap, air flow across the boundary of the borehole may occur as air flows through the geologic setting due to orographic effects. Characteristics of air in the borehole/container gap could be affected as air leaves the gap and is replenished from the geology by circulation through a "breathing" geologic setting. Such air transmission through the geologic setting would affect and be affected by elevated temperatures and temperature gradients, due to the thermal load from the radioactive wastes and by the vertical temperature and barometric gradients imposed on the land surface.

Heat-induced mineralogic change may cause dewatering of surrounding clays, which might influence the corrosion resistance of the waste-package components by changing the water volume in the pore spaces and the water-vapor content of the surrounding gases in the pore space. As a result of temperature changes, mineralogic changes in the host rock may occur. Such a change can iffect the movement of water in fractures containing expandable clays or zeolites and, in turn, potentially influence degradation of the waste containers. Data on the thermal responses of unsaturated media, in particular, are relatively scarce. Significant experimental observations will be required to fully understand the effect of thermal loads on the anticipated host geology and, consequently, on geochemical and geomechanical changes that might affect the waste packages in an unsaturated environment.

The volume of gas in the pore space in the host rock possibly will interact with containers in various ways, depending on oxygen content, liquid and gaseous water content, absolute temperature, and temperature regime. Some have calculated that gaseous oxygen in the pore spaces of the host rock might be purged entirely from the immediate vicinity of the waste packages, thus encouraging reducing conditions; others point out that, within the dry zone, hot, vapor-laden, oxygen-containing air returning toward the containers might lead to formation of a desirable passivating layer, composed of metal oxides and hydroxides, on the metallic components of the waste package. One additional theory suggests that the zone prosimal to the waste package will be absent of yir and become saturated with water vapor. The presence of water vapor can greatly influence the environment near the waste package. Certainly, the porosity and the fracture density and interconnectivity of pores and fractures in the host rock will influence the likclihood of certain interaction scenarios.

The effects of radiation upon the host geology may influence pore spacing, interconnectivity of pores and/or fractures, changes in mineralization, and the type and rate of generation of radiolysis products in the near-field. Radiolysis products could be influenced by the temperature of the waste package. The radioactive elements fueling radiolysis will have lessening radiation fields through time and should result in a changing environment in the water-gas-host rock system, with decreasing radiolysis products being present as time progresses.

As the temperature in the repository rises to a peak and then cooling begins, the type and physical condition of the host geology will affect the raie of decrease in size of the dry zone expected to surround the waste emplacement initially. As cooling ensues in the host geology, groundwater might return to the vicinity of the waste packages. The repository groundwater could pick up constituents from the backfill, host geology, and precipitates deposited during the warmer periods, thus increasing the ionic strength of the solutions. The high ionic strength solutions formed from host geology/groundwater interaction could increasc local corrosion rates. Mineralogic changes in the host rock could be induced by the reintroduction of water to previously dehydrated forms and by subsequent swelling of the host materials, with attendant results on the waste packages. Additionally, liquid water (containing these same minerals) that is suspended above the waste package by the heat pipe, could drain or drip onto the waste package during the heating phase after waste emplacement. 
The site-specific geology/waste-package material compatibility should be considered in the selection of materials for various components of the waste package; for examnle, copper and copper-alloys are more stable with basalt than with tuff/carbonate geology. Salt deposits would be plastic and would encapsulate the container; therefore, the container should be able to withstand the lithostatic pressures that would be generated. Certain rock types would generate more colloids than others as, for example, organic rich shales.

Other possible concerns related to geology would be the effects of human intrusion and the effects of site alteration such as boreholes, drifts, sealing, and other constructions on the environment. Construction and operation activities or later human intrusion could increase the likelihood of water penetration along manmade preferential pathways to the repository level and might result in accelerating or altering the degradation mechanisms operating within the geologic matrix adjacent to the affected boreholes, drifts, or seals. There might be additional detrimental effects on the corrosion of the waste packages due to the release of chemical species that adversely alter the chemistry of the "in-situ" water, if materials foreign to the local environment are introduced into the boreholes, shafts, or seals and consequently migrate to the immediate vicinity of the containers; e.g., the use of cement to plug boreholes or for sealing could allow elements that were catalytic or directly detrimental to corrosion of containers to become a part of the near-field environment adjacent to the affected borehole, shaft, or seal.

\section{Bibliography}

1. U. R. Evans, The Corrosion and Oxidation of Metals, London: E. Arnold and Co., 1961.

2. C. J. Hackbarth, T. J. Nicholson, and D. D. Evans, "Disposal of High-Level Radioactive Wastes in the Unsaturated Zone: Technical Considerations and Response to Comments," NUREG/1046, 1985.

3. National Academy of Sciences, A Study of the Isolation System for Geologic Disposal of Radioactive Waste, National Academy Press, Washington, D.C., 1983. 


\subsubsection{Volcanic and Seismic Hazards}

An important phenomenon that could conceivably affect the performance of the waste package is ground motion due to volcanic and seismic activities at or in the vicinity of the geological repository. The ground motion could cause displacement through joint slip, for example, of the rock in a tuff repository. Falling rocks could result in physical damage to the HLW container and other waste package components, which may compromise the ability of the waste package to provide containment. Volcanism may also increase the temperature of the repository and introduce new or alter existing fluids and gas chemistries, which could change or accelerate the degradation modes of the HLW package materials. Disruption of the geologic barrier by fault or joint displacement could significantly increase the gross permeability of the rock mass, which, in turn, could increase the amount of water available for corroding the wastepackage components. Other areas of concern are described in the two sub-sections on volcanotectonics and seismicity in this report.

In the analysis of the likely damage to the HLW container and the waste-package components in a repository situated in a rock mass, computational schemes that will model the dynamic behavior of jointed rock must be employed. In this regard, it is notable that dynamic soil-structure interaction schemes have been applied in the nuclear industry for some time. However, the nature of ground motion in the sub-surface is different from that on the surface, and jointed rock exhibits constitutive behavior quitc different from that of soil or salt deposits. Thus, experience gained in design analysis and performance prediciion for surface structures founded on soils may not be relevant to the problem of dynamic analysis of underground waste-package emplacement boreholes. Therefore, appropriateness of using seismic and volcanic data and lechnical information from a geologic setting different from the site being considered for the repository should be evaluated carefully before using it for estimating the potential damage to the waste package. 


\subsubsection{Volcanotectonics}

\section{Statement}

Volcanism and/or tectonics (volcanotectonics) may be a contributing factor that leads to changes in the modes/kinctics of degradation of container materials.

\section{Concern}

Volcanotectonics may affect indirectly the degradation modes/kinetics of waste-package materials in one or more of the following ways:

(1) changing the elevation of discharge and/or recharge areas, remote from the repository, thus causing changes in the geohydrology,

(2) changing the near-field stresses, leading to containers and linings being subjected to stresses exceeding their design limits,

(3) increasirig the repository temperature,

(4) introducing new or altering existing fluid and gas chemistries,

(5) altering the stratigraphic relations that could change the geohydrology and geochemistry of the site,

(6) significantly offsetting the discontinuities that transgress containers' emplacement sites.

(7) leading to sloughing and collapse of the emplacement hole with little change in pressure on the container.

The concern for the waste package is that these scenarios may result in significant detrimental mechanical and hydrological changes to the environment. Inadequate characterization of mechanical and hydrological responses of a repository with respect to volcanotectonics could lead to inaccurate predictions of the ability of HLW package to provide the required level of radionuclide containment.

\section{Basis}

Volcanotectonics is to be distinguished from seismicity in assessing possible effects on waste containers. Seismicity (e.g., earthquakes) are relatively short-term dynamic events. Volcanotectonics is a longer-term quasi-static process.

Mechanical changes resulting from volcanotectonics include changes in state of stress and changes in rock displacement. Changes in the stress state of a diffusion barrier, such as a bentonite backfill, could change characteristics of the barrier and adversely affect performance by changing permeability and or adsorption characteristics. Other mechanical effects could include shear offsets on discontinuities sufficient to cause wall rock and/or liner deformation such that the waste container is impinged. These shear offsets may cause containers to shear or bend, thus inducing stress concentrations in the container and possibly changes in the mode/kinetics of degradation of the container material. Volcanic forces could alsi) cause a change in the temperature field near the waste package, and as a result, change the base conditions without directly damaging the waste package. 
Hydrologic conditions in the iock mass may be altered as a result of volcanotectonics. Possible changes include permeability, degree of saturation, groundwater table elevation, and flow gradients. There could also be a change in fluid properties due to the introduction of more corrosive fluids or corrosion products. These changes, individually or in combination, could result in important changes in the local container environment.

\section{Bibliography}

1. J. S. Szymanski, "Conceptual Considerations of the Death Valley Groundwater System with Special Emphasis on the Adequacy of this System to Accommodate the High-Level Nuclear Waste Repository," U.S. Department of Energy, Nevada Operations Office, Waste Management Project Office, Internal Report, November 1987.

2. I. S. Carmichael and F. J. Turner, Igneous Petrology, McGraw-Hill, New York, New York, 1974.

3. B. Crowe, et al., "Aspects of Potential Magmatic Disruption of a High-Level Radioactive Waste Repository in Southern Nevada," J. Geology 91, 1983. 


\subsubsection{Seismicity Effects}

\section{Statement}

Seismic events could be a contributing factor to changes in the modes or kinetics of degradation of the waste package.

\section{Concern}

Seismicity may indirectly affect the degradation modes and/ or kinetics of the waste package in two ways: (1) it may induce mechanical instability of the container emplacement boreholes, possibly leading to the failure of one or more components of the waste package, and/or (2) it may lead to modification of hydrologic conditions in the repository, i.e., modification of ground-water flow patterns and levels. Changes in the ground-water level may result in a change of emplacement environment from an unsaturated to a saturated condition or vice versa. Inadequate characterization of mechanical and hydrologic responses of a repository with respect to seismic activities could lead to inaccurate predictions of the ability of the waste package to provide containment for the radionuclides.

Basis

Seismic events induce transient ground motion. The mechanical response of excavation (drifts and emplacement boreholes), near-field rock to transient ground motion, is determined by the usual range of site characteristics and excavation design variables. These include mechanical properties, structure and ambient state of stress in the host rock mass, shape and dimensions of the excavation, properties and design of support and reinforcement systems, and the specific nature of the imposed ground motion. Damage to waste containers from seismic events may involve one or more scenarios as follows.

1. Shear Offsets

Shear offsets on discontinuities could be sufficient to cause wall rock and/or liner deformation such that the waste package is impinged. 'These shear offsets may cause HLW containers to shear or bend, thus inducing stress concentrations and/or changes in the mode and/or kinetics of degradation of waste package materials, and

\section{Shaking}

Shaking could cause borehole spallation, roof falls, and/or wall rock loosening involving translational movement of rock blocks into emplacement boreholes. Waste packages in unlined boreholes may be damaged through the dynamic impact of individual blocks or by the resulting quasi-static external loads.

Two different time scales are involved in the seismic effect on hydrologic conditions in a rock mass. Immediate response involves groundwater changes attending passage of ground wave, such as water-well fluctuations and changes in the heat and water transfer conditions. Longer term pseudo-static response involves permanent changes in rock-mass conditions such as fracture permeability or hydrologic changes in water table and groundwater flow modification. In addition, some believe that seismic pumping may push groundwater from an aquifer below an initially unsaturated repository horizon to the host horizon, resulting in flooding of the repository. 


\section{Bibliography}

1. M. B. Balachandra, C. F. Bagge, and H. H. Haynes, "Low-Cycle Fatigue Tests of Hollow Concrete Spheres with Implications for the Survivability of Deep-Underground Rock Openings: Final Report, 4/27/77 - 1/31/78)," Agbabian Associates Report to U.S. Defense Nuclear Agency (DNA), Report No. AA-R-774-4551, DNA 4433F, April 1978.

2. J. D. Bredehoeft, S. F. Riley, and E. A. Roeloffs, "Earthquakes and Groundwater," Earthquakes and Volcanoes, 19 (4), 1987.

3. C. H. Dowding and A. Rozen, "Damage to Rock Tunnels from Earthquake Shaking," J. Geotech. Engrg., 104 (GT2), 1978.

4. R. G. Raney, "Reported Effects of Selected Earthquakes in the Western North American Intermontane Region, 1852-1983, on Underground Workings and Local and Regional Hydrology: A Summary," NRC FIN D1018, April 1988.

5. C. M. St. John and T. F. Zahrah, "A Seismic Design of Underground Structures," ITA Working Group on Seismic Effects on Underground Structures, National Science Foundation, Grant No. CEE-8310631, Tunnelling and Underground Space Technology, 2 (2), 1987.

6. J. S. Szymanski, "Conceptual Considerations of the Death Valley Groundwater System with Special Emphasis on the Adequacy of this System to Accommodate the High-Level Nuclear Waste Repository," U.S. Department of Energy, Nevada Operations Office, Waste Management Project Office, Internal Report, November 1987. 


\subsubsection{Radiation and Radiolysis}

\section{Statement}

The radioactive content of the HLW container (vitrified waste form and spent fuel) will generate a radiation field and will produce new chemical species not present in the repository at the time of waste package emplacement via interactions of radiation with the environment.

\section{Concern}

The effects of a gamma radiatic $n$ field provided by the radioactive inventory of the HLW containers could have adverse effects on the performance of waste-package components in a repository environment. The radioactive contents of the HLW container provide a unique environment that could interact with and change the existing repository environment, the geologic setting, and the container material. The interactions could possibly lead to new degradation modes or an acceleration in the rates of degradation observed in the absence of a radiation field. The radiation interactions could compromise the ability of the waste package to perform as intended.

\section{Basis}

The intense gamma radiation field expected to exist in the vicinity of the container for the first few hundred years could aiter the environment, resulting in rapid deterioration of the waste-package components. Gamma radiation could lead to phase transformation of less soluble constituents of the rocks or minerals to phases and minerals that are highly soluble in water. In the event of water intrusion into the repository, the transformed minerals with higher solubility could form liquids in the container borehole that are much more corrosive.

Another likely effect of the gamma radiation field is the radiolysis of water, vapor, and gases present in the repository. This could lead to the generation of highly corrosive compounds like hydrogen peroxides, ammonia, nitrogen oxides, carbonic acid, nitric acid, and other chemicals that could have deleterious effects on the container material. Gamma radiation could also alter the properties of passive films formed on corrosion-resistant alloys. Separate as well as synergistic effects of radiation with the major variables must be considered. These include not only the environment in the repository at the time of emplacement, but also changes in environment, geology, and hydrology with time.

The understanding of the effects of radiation will have to be demonstrated for the purpose of predicting the useful service life of the waste package in a repository environment. Techniques used to simulate the long-term radiation effects, other than just increasing the dose rate, may have to be developed and shown to be an appropriate surrogate for time.

\section{Bibliography}

1. W. G. Burns, W. R. Marsh, W. S. Walters, Radiat. Phys. Chem., 21, p. 259, 1983.

2. A. O. Allen, The Radiation Chemistry of Water and Aqueous Solutions, D. Van Nostrand and Co., Inc., Princeton, New Jersey, 1961.

3. J. W. T. Spinks and R. J. Woods, An Introduction to Radiation Chemistry, 2nd ed., John Wiley and Sons, New York, New York, 1976. 
4. S. C. Lind, Radiation Chemistry of Gases, Reinhold Publishing Corp., New York, New York, 1961.

5. N. Fujita, M. Akiyama, and T. Tamura, "Stress Corrosion Cracking of Sensitized Type 304 Stainless Steel in High Temperature Water under Gamma Ray Irradiation, " Corrosion-NACE 37 (6), pp. 335-341, June 1981. 


\subsubsection{Microbial Environments and Effects}

\section{Statement}

Literature on microbial corrcsion shows that attack on metals in the form of pitting corrosion, crevice corrosion, and stress corrosion cracking can be accelerated by the presence of microbes in the soils and waters. Therefore, there is a possibility of accelerated attack on the container material due to the biological activities of some types of microorganisms that might exist or be introduced in the repository as a result of the repository construction and operation activities.

\section{Concern}

Microbes in the waste package environment may accelerate or change the modes by which components of waste package are affected over time. The resulting alterations may involve degradations that are more severe than those predicted in the mechanistic arguments or in bounding calculations used in performance assessments.

\section{Basis}

Extensive research to investigatc the kinds of microbes and bacteria that may be present, survive, and grow in deep geological repository settings has not been done. The reason presumably is that the anticipated presence of high radiation fields and elevated temperatures in the early part of the repository life would sterilize the local environment. However, after a few hundred years, the temperature of containers containing vitrified waste will drop below the boiling point of water, allowing liquid-phase water to come in contact with the containers. Some forms of microbes have been reported to exist and multiply in waters at the temperatures expected in a geologic repository, and have been reported to lead to accelerated degradation of metallic materials.

The microbial attack on metals usually manifests itself in accelerated corrosion or a change in the cotrosion mechanism, due to aggressive chemicals produced by microorganisms. A vast amount of literature exists on microbial corrosion and degradation of materials; therefore, only a few selected examples will be given here. These include the possible effects of some types of microbes in the changing repository environment leading to accelerated degradation of the container material.

At least 37 types of organisms are known to be associated with corrosion. The biological mechanisms through which these microbes play a role in degrading metallic materials are varied. For example, by consuming oxygen, many organisms create concenuration cells, which can lead to crevice corrosion-type attack on some metals surfaces, such as stainless steels. The metabolic production of $\mathrm{CO}_{2}$ by other microbes creates carbonic acid, which is corrosive to metals generally. Many microbes also produce organic acids under biofilms on the metal surfaces, leading to a pitting type of attack.

One variety of microbe, Desulfovibrio desulfuricans, considered deleterious to copper and copper-based alloys, is a sulfate-reducing bacterium (SRB). These bacteria can coexist with oxygenscavenging microbes, and can reduce sulfate to produce $\mathrm{H}_{2} \mathrm{~S}$ or FeS. These compounds are highly corrosive to many alloys including noncuprous materials such as stainless steels and nickel-base alloys. The SRB are most effective in reducing inorganic sulfates to sulfides in the presence of hydrogen or organic matter, and are aided by the presence of an iron surface. The SRB grow in anaerobic conditions, but the degree of adaptation to an oxygenated environment needs to be studied. Generally, stainless steels containing high amounts of sulfur are not recommended for use if the presence of SRB is anticipated. 
Another type of bacteria, Thiobacillus ferrooxidans, are known to oxidize sulfides to sulfates producing sulfuric acid, which is very corrosive to copper and copper-based alloys. Thiobacillus ferrooxidan may also oxidize other species in the water such as ferrous ions to ferric ions, which can lead to accelerated corrosion of metals. Another area of concern is the possibility of microbes aiding in migration of radionuclides to the biosphere upon failure of the HLW container.

Since many varieties of microbes exist, survive, and grow optimally under different type of environments, the evaluation of effects of microbial activities on the container material degradation will have to take into consideration the specific characteristics of the repository site.

\section{Bibliography}

1. H. H. Uhlig and R. W. Revie, Corrosion and Corrosion Control, 3rd ed., John Wiley \& Sons, New York, New York, 1985.

2. A. W. Fletcher, "Copper Recovery from Low-Grade Ore by Bacterial Leaching," Microbial Aspects of Metallurgy - Chapter 8, American Elsevier Publishing Co., New York, New York, 1970.

3. J. D. Stoecker and D. H. Pope, "Study of Biological Corrosion in High Temperature Demineralized Water, " presenter at the CORROSION '86 Conference in Houston, Texas, June 1986.

4. D. H. Pope, R. J. Soracco, and E. W. Wilde, "Studies on Biologically Induced Corrosion in Heat Exchanger Systems at the Savannah River Plant in Aiken, South Carolina," presented at the CORROSION ' 82 Conference in Houston, Texas, March 1982.

5. R. E. Tatnall, "Fundamentals of Bacteria Induced Corrosion," presented at the CORROSION '81 Conference in Toronto, Ontario, April 1981.

6. R. E. Tatnall, "Case Histories: Bactcria Induced Corrosion," presented at the CORROSION '81 Conference in Toronto, Ontario, April 1981.

7. C. Ringas and F. P. A. Robinson, "Corrosion of Stainless Steel by Sulfate-Reducing Bacteria -- Total Immersion Test Results," Corrosion Engineering 44 (9), 1988.

8. A. J. Francis, et al., "Microbial Transformations of Uranium and Toxic Metals in Depleted Uranium Wastes," Abstract No. 2D-3, presented at the Migration 89 Conference in Monterrey, California, September 1989. 


\subsubsection{Container Internals}

Statement

The contents of the waste container probably will react with the container. Therefore, the ability of the waste package to provide containment for its contents may be determined by ine degradation modes applicable to the container inside rather than the outside surfaces.

\section{Concern}

The HLW containers may contain spent fuel rors, assemblies, other fuel assembly hardware, vitrified waste (defense or civilian) enclosed in pour canisters, internal fixtures to support the contents, and a gaseous medium to protect the fuel cladding and $\mathrm{UO}_{2}$ in failed fuel rods from degradation. Some of the contents may not be compatible with the container material, and under some adverse conditions, accelerated degradation of the HLW container may occur from inside.

\section{Basis}

There may be several different types of materials in the container, such as fuel rods fabricated from Zircaloy-2, Zircaloy-4, zirconium-niobium alloys, zirconium-lined Zircaloy-2, or stainless steels; fuel assembly hardware made of various grades of stainless steels, high-nickel and high-chromium alloys; pour canisters of Type 304L stainless steel containing reprocessed waste; and container fixtures (various materials). In addition, the fuel rods are expected to have a thick oxide layer from years of service in power reactors and subsequent storage in spent fur' pits. The oxide ma y contain contaminants from the coolant (like boron and lithium hydroxide) and from the secondary side of the power plant, nickel from steam generators, or copper from condensers. Furthermore, some of the fuel rods may fail after emplacement of the HLW container in the repository or may be water-logged. The water-logged rods have the potential for releasing radioactive gases and corrosive chemical species from the $\mathrm{UO}_{2}$ fuel pellets. Another adverse situation may arise if a pin-hole breach in the outer container lets in air, water vapor, and radiolysis products from outside into the inside of the container.

These possible internal situations could provide a much more aggressive environment than that prevailing on the external surface. Under such conditions, a galvanic corrosion cell could be set up, which could lead to rapid degradation of the fuel cladding or the outer container. Either situation has potential for accelerating the degradation of other components of the waste package. Migration of the wasted metal products to nearby containers could add additional complexity. Also, rapid deterioration of other unfailed containers in the vicinity could occur because of the buildup of a more aggressive corrosion environment. This is an example of how a failed container (due to internal degradation) could compromise the ability of other unfailed containers to provide containment.

Therefore, it is necessary to study the effects of (1) releases of gases, vapors, and liquids from the fuel rods and the vitrified waste pour canisters, and (2) other interaction products of the internal contents on the internal and external degradation modes of the HLW container. Again, similar to the external degradation modes, scientific understanding of the interna! degradation modes of the container has to be obtained and should be demonstrable for the purpose of making long-term projections of the performance of the waste package, based on short-term laboratory test data. 
1. J. W. Braithwaite and M. A. Molecke, "Nuclear Waste Canister Corrosion Studies Pertinent to Geologic Isolation," Nuclear and Chemical Waste Management, 1, pp. 37-50, 1980. 


\subsection{Materiaks and Fabricatlon}

Specifications are needed to assure that properties and design requirements for materials of construction for the waste package and for intermediate and final products as established by designers will be met. The specifications serve as a link among the designer, the fabricator, and the inspector. They are used to assure that 1) the properties and characteristics of the materials placed into service match those shown to be needed for the application, and 2) appropriate quality control standards are used. Fabrication of various waste package components requires quality control through the use of qualified equipment, trained operators, approved fabrication procedures, in-process and final product examinations, and verification tests. Inspection criteria and reports are required to confirm the acceptability of the components. 


\subsubsection{Quality Control}

\section{Statement}

Quality control involves actions related to the characteristics of a material, structure, component or system, and provides a means by which conformance with predetermined requirements can be ensured.

\section{Concern}

The actual performance of waste package components emplaced in the repository may not mect the design requirements. The properties and behavior of prototypes may not be replicated acceptably in the production ol a large number of components.

Basis

The waste package designs and specifications are developed based on mechanistic understanding of alteration processes, results of laboratory testing, testing of prototypical components, extrapolation through modeling, and engineering judgment. These are used to select a material to meet specific performance objectives.

A quality control plan gives assurance that a product has been manufactured or constructed according to the specified design. As noted, quality control involves actions related to the characteristics of a material, structure, component, or system that provides a means to ensure conformance to predetermined requirements. It is also a sei of actions that is planned to ensure that the processes through which waste is received, encapsulated, and emplaced fulfill predetermined requirements. The state of the materials used for containers should be fully characterized before fabrication and throughout the different steps in the fabication process. Requirements and specifications for waste-package materials should include containers and other components of the waste package.

For thousands of waste packages that are located in the repository, conformance to specifled requirements through a thorough quality control plan provides reasonable assurances that defects that might lead to premature fallure of components a not present.

Examples of actions to be included in a quality control program are dimensional measurements of components, mechanical tests to evaluate strength, ductility, or toughness, standardized corrosion tests for localized corrosion, in particular, intergranular corrosion, etc., as well as specific nondestructive and destructive tests for weldments.

\section{Bibliography}

1. J. M. Juran and F. M. Gryna, Jr., Quality Planning and Analysis, McGraw-Hill, New York, New York, 1970.

2. Metals Handbook, 17 Non-Destructive Examination and Quality Control, 9th ed., ASM International, Metals Park, Ohio, 1989. 


\subsubsection{Materlals Specifications}

\section{Statement}

Materials speciflcations define the properties and characteristics belleved to be needed for acceptable service life of components.

\section{Concern}

Deviations of materials properties and characteristics outside the range permitted in specifications can give rise to uncertainties that may lead to unacceptable service life.

Basis

As components are being fabricated, appropriate materials specifications are required for the procurement of materials. Specifications such as those given in the Annual Book of ASTM Standards should be adopted. It is recognized that these types of standards are not design specifications and, therefore, they do not take into account the expected service conditions, except in a very limited way. Thus, materials standards of the type available through the American Society for Testing and Materials (ASTM) can be used to assure only that the characteristics of the as-received materials or the as-fabricated components are similar to those of critical test specimens or of prototypical components used to makc service-life predictions. The required supplement to these specifications is the scientific understanding that relates environmental conditions to the behavior of a component in a repository. When this understanding is available, the service requirements needed for design specifications can bo established so as to ensure that the long-term performance objectives can be met.

The requirements for a waste-package design are defined in a set of specifications, related to materials quality, production methods, chemical composition, fabrication procedures, thermomechanical treatments, and repair procedures. The specifications are used to ensure that the properties of wastepackage components are consistent with the requirements for repository service. The specifications dictate the nature and quality of the components and thereby make calculations of their durability possible. These specifications furnish guidelines for fabricators who must supply acceptable products. The specifications also guide inspectors in their determinations of compliance with the requirements.

The properties and/or characteristics that are commonly specified and monitored for engineering materials can be broadly classified as chemical, physical, microstructural, and design-related. Examples of properties that require specifications are the chemical composition of an alloy (including ranges for the alloying elements and acceptable maximum limits of trace and impurity elements) and mechanical properties, such as strength, ductility, etc. Characteristics to be considered include level of residual stresses, microstructure (including grain size, amount of cold work, and morphology of impurity elements such as stringers in rolled product), texture of rolled product, surface finish, and surface flaws. In addition, weld defects (e.g. poor penetration, undercutting, porosity, excessive grain growth, etc.), as well as alterations induced by welding (grain-boundary segregation, and microstructure in the weld heat-affected zone (HAZ)), should be considered.

Specifications are related to performance through the best available scientific understanding, which is developed by testing, theoretical and analytical considerations, and other means. Commonly, performance can be demonstrated only for products within a narrow range of properties. In this case, for example, the chemical properties can be characterized by nominal compositions. In addition, a range of permitted values is frequently needed to specify completely materials properties and characteristics. In many cases, local variabilities in the content of alloying elements are known to have significant effects 
on service behavior, but these variabilities are usually measured and assessed for their significance. Metallurgical remedies or countermeasures may be required to elimind is reduce any significant effects. These assessments and remedies are, in part, responsible for the establishment of permitted composition ranges for each alloying element and maximum values for certain impurity elements.

For waste-package components, materials requirements and specifications should take into account the entire service life, including the repository preclosure period. Requirements for waste-package service should include the requirements to supply materials in accordance with good engineering practice, as, for example:

1. Acceptance criteria are used to ensure compliance with specifications developed from all available information.

2. Materials specifications can be written with a high degree of verifiable assurance that the quality of the components actually produced matches that required under applicable specifications, as, for example, for items such as material identification, heat treatments, adherence to established processing procedures, compliance with specified composition, mechanical properties, and other acceptance criteria, as appropriate.

3. Materials qualification tests can be used to qualify materials for use by ensuring that they meet design specifications.

4. For both the materials and the components, permitted deviations from specifications shall be only those that can be accommodated by the use of safety factors. This accommodation for all engineering uncertainties is consistent with the intent to furnish a conservative design. Likewise, scientific uncertainties can be appropriately factored into calculations through the use of bounding conditions that lead to conservative predictions.

Fitness of a component for waste-package service can also involve assessments of the materials characteristics that control long-term durability. As most existing specifications do not address these lypes of assessments, they will have to be developed for each component, based on a life-cycle analysis that takes into account the environmental conditions and expected service life.

\section{Bibliography}

1. Annual Book of ASTM Standards, 01.02, 02.01, and 02.04, American Society for Testing and Materials, Philadelphia, Pennsylvania, 1989.

2. Metals Handbook 1 , 10th ed., ASM International, Metals Park, Ohio, 1990.

3. Metals Handbook, 2, 9th ed., ASM International, Metals Park, Ohio, 1982. 


\subsubsection{Materials Characterization}

\section{Statement}

To ensure that components selected for use will be acceptable in service, materials characteristics and the variability of these characteristics are known and related to service performance.

\section{Concern}

The variability in the characteristics and properties of the large number of waste-package components in a repository may be so large that the acceptable behavior, as demonstrated either for test specimens or for a prototypical component of a waste package, may not be representative of the actual behavior.

Basis

'T'o demonstrate that a material is suitabie for some aspect of repository service, it is important to understand the characteristics of the material in relation to the requirements of that particular aspect of repository service. The variability of the characteristics, as measured by selected parameters, can be significant. Materials with high variability may prove to be unsuitable for production of a large number of waste packages.

Service performance can be related to various characteristics. For example, the yield strength may govern buckling under compressive loads; a given thickness of protective coating may be needed to give 1000 years of corrosion protection; only compositions within a specified range may furnish a thermodynamically stable alloy, etc. The values of the parameters used to assess these characteristics can vary significantly in production. Among the factors to be controlled in production lots for large numbers of waste packages are raw materials, production methods, fabrication procedures, and transpurtation processes. Each of these factors may give rise to variabilities important to service behavior.

The task is to determine which characteristics affect service behavior, and to know and to specify the acceptable ranges for pertinent parameters that can be related to expected service performance. For example, in a metallic canister, the pertinent characteristics might include microstructure, chemical composition, and mechanical and physical properties like strength, ductility, grain size, texture, and the amount of cold work. Some of these characteristics may be relatable to service behavior, and the understanding of the relationships must be sufficient to determine the limiting values for these characteristics, as measured by various parameters, such as the percentage of carbon, the maximum and minimum values for alloying and impurity elements, the ASTM grain size number, the 0.2-percent-offset yield strength, etc.

Examples of variabilities that could lead to unexpected behavior in service are cited below:

(1) Over time, materials suppliers may change, and the properties and behavior of components used in the early years may differ from those in later years.

(2) For an alloy prepared to a standard specification, the chemical composition can vary from heat to heat.

(3) Within a single heat, plate-to-plate variabilities and the variabilities from the center to the surface (or to the edges) of a plate may be significant. 
Tests used to predict repository behavior of a component must be conducted under conditions that represent those expected for an as-emplaced component in a waste package. For example, standardized corrosion tests may require the surface of the test specimens to be specially prepared (electropolished, degreased, mechanically polished, etc). Although this may be acceptable for a determination of the relative ranking of materials, it may not be suitable for representing the expected service behavior of an emplaced HLW container. In the repository at the time of emplacement, a container surface may differ from the as-polished surface of the test specimen, and the container surface may change significantly over the long period required for acceptable scrvice. Thus, the test condition would not match the service condition, and the evaluation must take this into account. In this case, perhaps bulk properties, or some measured properties, in the prescince of surface oxidation products, may be required to aid in prediction of the long-term performance of the container.

Variations in chemical compositions must be taken into account in determinations of the acceptability of prototypes drveloped from the (electrochemical) test data. For example, tolerance limits for sulfur impurities can be developed on the basis of the best understanding and acceptance tests conducted at acceptance limits.

Adequate testing must be conducted to determine the inportance of various characteristics of materials and to document that limiting values for pertinent parameters used to evaluate these characteristics are known. Using appropriate ranges for these parameters, specifications, and requirement can be written with assurance that the prototypes represent the products of the large-scale production. Hence, detailed characterization of materials and their properties may be needed to furnish assurance that the behavior of components placed into service will be similar to that of the components tested as prototypes.

Wherever possible, standardized tests such as those published by ASTM, American Society of Mechanical Engineers (ASME), and National Association of Corrosion Engineers (NACE) should be used. However, some widely used tests may also be used in preliminary screening, for example, by running a series of constant-extension-rate-tests (CERT). These tests can provide information about the loss in ductility and the load-bearing capacity of the metal in the test environment, and they could be indicative of the sensitivity to an environmental condition. Where standardized methods are not available, specific tests will have to be developed for use in repository licensing.

\section{Bibliography}

1. Metals Handbook, 10, 9th ed., ASM International, Metals Park, Ohio, 1986.

2. S. W. Dean, E. N. Pugh, and G. M. Ugiansby (eds.), Environment-Sensitive Evaluation and Comparison of Test Methods, STP-821, American Society for Testing and Materials, 1984.

3. R. Baboian (ed.), Electrochemical Techniques for Corrosion, National Association of Corrosion Engineers, Houston, Texas, 1977.

4. W. H. Ailor (ed.), Handbook of Corrosion Testing and Evaluation, John Wiley \& Sons, New York, New York, 1971. 


\subsubsection{Fabrication Process Specifications}

\section{Statement}

The properties and characteristics of fabricated products are functions of the fabrication specifications processes. The fabrication specifications describe the fabrication processes in order to ensure the necessary performance of waste-package components.

Concern

Fabrication processes may accelerate the degradation rates of waste-package components. Specifications of inadequate quality could lead to poor fabrication practices and result in large variabilities in performance of these components.

Basis

Fabrication-related considerations include, among others, residual stresses, welding parameters, alloying and impurity elements, microstructure, thermomechanical treatments, and impurities picked up from the environment during fabrication.

For example, adverse effects of welding are numerous, and they result from a variety of causes. Many of the commonly used engineering materials, particularly stainless steels, when welded, undergo metallurgical phase transformations and segregation of alloying elements, which may alter mechanical properties and corrosion behavior. Sometimes, problems are caused by improper choice of filler metal, welding technique, and/or post-weld heat treatment.

Fabrication procedures can greatly affect the properties that govern the behavior of fabricated products and so, to ensure acceptable behavior, the characteristics of both the as-received materiais, as well as those of the fabricated products, must be known. Procedures required to reprir components, e.g., through welding, can play an important role in materials selection. The selection process involves consideration of any required post-fabrication thermomechanical treatments. In tivis application, the materials selection process will focus on the ability to demonstrate acceptable, long-term service performance of fabricated components under repository conditions.

Fabrication specifications permit the production of large numbers of components with a narrow range of properties and with characteristics that are consistent with the design requirements. An example of high-quality welding sperifications can be the ASME Boiler and Pressure Vessel Code, Section IX, "Welding." Although these specifications are not necessarily tailored to the needs of waste-package components, they do contain many features needed to manage fabrication quality.

A specification for welding, for example, should include the following:

1. Process - Gas Tungsten Arc Welding (GTAW), Gas Metal Arc Welding (GMAW), Shielded Metal Arc Welding (SMAW), friction welding, etc.

2. Materials - filler metal, flux, atmosphere

3. Preheating, post-weld heat treating, and inferpass temperature control

4. Joint geometry 
5. Quality control - includes qualification tests for weldments and welders, standard mechanical tests, corrosion tests, and nondestructive testing of weldments.

6. Repair procedures for various types of damage that could occur as results of improper handling or fabrication techniques.

\section{Bibliography}

1. ASME Boiler and Pressure Code -- Section IX, Welding and Brazing Qualifications, American Society of Mechanical Engineers, New York, New York.

2. "Standard Methods for Mechanical Testing of Welds," ANSI/AWS B4.0-85, American Welding Society, Miami, Florida.

3. Metals Handbook 6, 9th ed., ASM International, Metals Park, Ohio, 1984. 


\subsubsection{Metal Stability}

Most engineering materials of construction are alloys of two or more elements. These alloys can undergo phase separation or transformations, resulting in a thermodynamically more stable multiphase microstructure or resulting in a single-phase structure with second-phase particles or intermetallic compounds. There is a concern that more stable phases, in some cases, may have undesirable or unacceptable characteristics, e.g., lack of adequate ductility, high susceptibility to attack by oxygenated waters or radiolytic products of repository gases, vapors, and liquids. In addition, these phases may be electrochemically anodic to other phases in the microstructure and may lead to galvanic cell behavior and galvanic corrosion on a microscopic scale. The kinetics of these very slow transformations, thermodynamic instability of the metallurgical phases, and the properties of nore stable resulting microstructures need to be studied and understood in order to determine the acceptability of selected material for fabricating waste-package components for a geological repository. 


\section{Statement}

Stability of a material is related to its rate of transformation (which can often be detected by examination of the microstructure) with time, temperature, exposure to radiation field, or other changes in the environment to which it is exposed.

\section{Concern}

Many engineering materials of construction are thermodynamically unstable or metastable. Therefore, there is concern that such materials, while in use in a geological environment, may transform with time to materials with less desirable or unacceptable properties. The concern arises primarily because of the extremely long service requirement in a thermal and radiation field.

\section{Basis}

Almost all common metallurgical microstructures aie in nonequilibrium with their surroundings and can transform to more stable metallurgical phases under certain conditions. Phase transformations begin with the appearance of a number of very small particles of the new phase, which then grow until the change of phase is complete. It is possible to predict, from xinetic principles, the temperature dependencies of nucleation and growth and, therefore, the overall transformation rate (however, heit generation arising from radioactive decay makes the prediction much more complicated).

Through such predictions and microstructural observations, it is found that two common types of widely used stainless steels, viz. Types 304 and 316 (both regular carbon content and low-carbon grade) are metastable because of the possible coexistence of body-centered cubic and face-centered cubic phases. These stainiess steels are also susceptible to intergranular stress corrosion cracking (IGSCC) when subjected to a sufficiently severe environment involving stress, corrosive environment, and a thermal exposure in the 'sensitizing' temperature range $(500)$ to $850^{\circ} \mathrm{C}$ ). This is duc to formation of $\mathrm{M}_{23} \mathrm{C}_{6}$ intermetallic carbide particles at the grain boundaries. This leads to a narrow chromium-depleted zone, adjacent to the carbides, which is much more susceptible to aqueous corrosion attack than the rest of the microstructure.

In copper-based binary alloys, iron is often added in small quantities to increase the corrosion resistance and improve the mechanical strength of the alloy. The iron is often present in a finely dispersed second phase as delta-iron. There is a concern that long-term phase transformation kinetics/migration of the second-phase iron and its consequences on the corrosion and mechanical properties of the wastepackage components may not be desirable or acceptable. In addition to the concerns of the instability of a single-phase microstructure or the thermodynamic metastability of the two-phase microstructure under an elevated thermal field, there are uncertainties associated with the kinetics of phase transformation under gamma radiation, for extended periods of time.

The above referred discussion provides examples of the kinds of concerns that exist about the stability of the base metal that might be used for fabricating components of the HLW package. These concerns, related to metallurgical phase stability, will have to be addressed through analyses based on fundamental understanding of the thermodynamics and rate kinetics of the phase transformations likely over the very long service life in a repository. 


\section{Bibliography}

1. G. M. Gordon, "Physical Metallurgy of Fe-Cr-Ni Alloys," (R. W. Staehle, et al., eds.), Proceedings of Conference on Stress Corrosion Cracking and Hydrogen Embrittlement of Iron-Base Alloys, NACE-5, 1977.

2. Metals Handbook 2, 9th ed., ASM International, Metals Park, Ohio, 1979.

3. A. J. Sedriks, Corrosion of Stainless Steels, John Wiley \& Sons, New York, New York, 1979.

4. E. G. West, Copper and Its Alloys, John Wiley \& Sons, New York, New York, 1982.

5. W. Betteridge, Nickel and Its Alloys, John Wiley \& Sons, New York, New York, 1984. 
Statement

Regardless of how the HLW container is fabricated, it is very likely to have one or more joints and closures. The properties of these joint or closures and their long-term behavior in a geologic repository environment could be quite different from those of the container base metal.

\section{Concern}

If the degradation rates of the container closure and joints are higher than those for the base metal in a geologic repository environment, then the response of the closure or joints will become the life-limiting criterion (rather than the degradation modes applicable to the container bulk material).

Basis

Many of the commonly used engineering materials, when welded, go through metallurgical phase transformations that produce embrittling metallurgical phases in joints, and this may lead to inferior mechanical and/or corrosion properties. Proper choice of filler weld material, welding technique, and/or post-weld heat treatments can reduce the undesirable effects that are sometimes associated with weldments, but one may have to accept some degradation of the materials and account for it in the design, performance evaluation, and useful life determination of the degraded product.

An example of a problem that has to be evaluated seriously in austenitic stainless steels is their susceptibility to develop a sensitized microstructure when exposed in the 500 to $800^{\circ} \mathrm{C}$ temperature range. Sensitization exposures can occur during fabrication and welding processes that may be used for the wastepackage components. The sensitized material exhibits much lower impact strength, and has a higher susceptibility to intergranular stress-corrosion attack. Another example of thermal stability concern, related to welding, is in commonly used ferritic stainless steels. Welding of these steels is considered to be a problem because of coarse grains and the martensitic structure that develop in the weld and HAZ. These changes lead to significant changes in the mechanical properties of the welds.

The above two examples relate to welding (thermal effects) in steels; however, the problem of metallurgical phase stability in joints and closure welds is pervasive to all materials and should be addressed in the context of other important repository environmental conditions. Examples of these conditions include the effects of gamma radiation emanating from the container, the radiolysis products formed from vadose vapor and liquids, due to the gamma radiation field, and the temperature in a waste package.

The broader questions related to joints and closures welds can be summarized as follows: (i) are the joints and closure welds susceptible to any degradation modes in addition to those applicable to the base metal; (ii) are the kinetics of degradation of joints and closure welds faster than those of the base metal in a repositcry environment; and (iii) can the waste package still provide the required level of containment in spite of the difference in the behavior of its bulk material and its joints and closure welds, including the HAZ?

\section{Bibliography}

1. F. B. Pickering, "Some Aspects of the Heat Treatment of Welded Corrosion- and Heat-Resisting Steels," in Heat-Treatment Aspects of Metal Joining Processes, 84 , The Iron and Steel Institute, London, 1972." 
2. K. O. Williams, "Further Studies of the Iron-Chromium System," Trans. Met. Soc. of AIME, 212, 1958.

3. R. D. Stout, Weldability of Steels, Welding Research Council, 1987.

4. T. Takalo, N. Suutala, and T. Moisio, "Austenitic Solidification Mode in Austenitic Stainless Steel Welds," Metall. Trans., 10A, p. 1173, August 1979.

5. N. Suutala, T. Takalo, and T. Moisio, "Austenitic-Ferritic Solidification Mode in Austenitic Stainless Steel Welds, "Metall. Trans., 11A p. 717, May 1980.

6. M. J. Cieslak, T. J. Headley, and A. D. Romig, "The Welding Metallurgy of Hastelloy Alloys C-4, C-22, and C-276," Metall. Trans., 17A p. 2035, 1986. 


\subsection{Degradation Procesces}

The behavior of a material depends upon the environment to which it is exposed. In man-made environments, the response of a material usually can be controlled and predicted quite accurately by keeping the environment within narrow well-defined bounds. An example is the LWR core environment and the response of fuel cladding containing uranium dioxide pellets. However, in a geologic repository, a number of uncertainties could exist about the environment. The predictability of the waste package in providing containment for radionuclides will depend not only on how well the geologic repository environment is known at the time of waste canister emplacement, but also on the validity of predictions of changes in the environment for many hundreds or thousands of years after the repository is sealed. The interactions between the changing repository environment and the waste-package materials need to be understood well in order to demonstrate that the waste package will meet its design objectives and required functions.

This section of the report provides some information on the possible modes of degradation that could be applicable to the components of a waste package in a geologic repository. Although the discussion of the materials degradation modes provided in this report generally applies more to metallic materials, it is recognized that nonmetallic materials and nonmetal/metal systems, such as ceramics (oxides, nitrides, carbides), cermets, composites, bonded metal-ceramics, graphite, polymers, surface modified and/or amorphous metallic or vitrified materials, may be used for the canister and other components of the waste package. The identification of likely failure modes of these nonmetallic and advanced structural materials in a geological repository environment could present additional challenges. The studies on the degradation modes of these materials should provide, as appropriate, a thorough understanding of the mechanisms involving delamination; metallurgical phase stability; effects of thermal and radiation fields; low temperature, long-term diffusion of alloying elements; and properties of the interface. 


\subsubsection{Gasw Metal Interactions/Oxidation}

\section{Statement}

If the selected geological repository is hydrologically unsaturated at the beginning of the repository life and if it is expected to remain unsaturated for a long period of time, then the effects of repository gases on the HLW canister should be considered. Oxygen is likely to be the principal gas of concern, and is expected to be present in a large quantity in an unsaturated repository. Other gases that may have deleterious effect on the canister material also could be present in the repository or could be generated by corrositon of the canister material, as for example, hydrogen. Gases such as methane can also bo exsolved from the repository geology as the pressure is reduced. Another possible mechanism by which gases from the outside environment could be introduced into the repository is via heat pipes, especially when two-phase flow is present.

\section{Concern}

Extended exposure of metals to high-temperature oxygen-containing gases leads to formation of a surface oxide layer. The characteristics of the surface oxide formed during the time when only gaseous or vapor phases are present in the repository environment could influence the later aqueous corrosion upon iritrusion of water into the geologic repository. Therefore, inadequate understanding of the characteristics of the surface oxide formed in the gascous phase, with and without the presence of moisture, could result in incorrect predictions of the ultimate useful life of the waste package in a repository environment. In addition, there is a concern related to the possibility of attack from the inside of the container, due to release of liquids containing radioactive species from water-logged fuel rods, and by the fission gases that might be released from fucl rods that might fail after they are sealed in the HLW containers.

Basis

The environment in an unsaturated repository could be quite complex and aggressive during the early years. The complexities likely to arise could be from much higher amounts of oxygen, nitrogen, and carbon dioxide, than might be present in a fully saturated repository environment. (Oxygen, nitrogen, and carbon dioxide solubilities in water are much lower than concentrations in air.) Coupled with these concentrations could be a much higher concentration of radiolytic species resulting from gamma radiation ficld dissociation of moisture and gases present in the repository (because liquids are not present in sufficient volumes to reduce the effects of radiolysis products by volume dilution).

The above-mentioned, plus other factors, could have a profound effect on the oxide layer that forms on the container during the first few decades to few hundred years after emplacement. Variations may occur in oxide thickness, tenacity, porosity, content of impurity elements, stress build-up, tendency for spallation, and regenerative behavior of new oxides that form on the spalled regions. The early oxide film, formed during the gascous or vapor environment in the repository, could influence the subsequent aqueous corrosion of the canister metal. All of these concerns need to be addressed through (1) understanding of the mechanisms involved, and (2) by obtaining data related to the kinetics of nucleation, growth, spallation, and regeneration of the surface oxide in the gaseous, vapor, and aqueous phases, in order to properly model the waste-package performance in a repository environment.

If oxidation processes are not well understood, the rate of oxidation in the repository could be much higher than the predicted rates and this could lead to unacceptably high amounts of wall thinning. For example, gamma radiation may greatly alter the oxidation rate by affecting the semi-conducting properties of the surface oxides. In addition, grain boundary migration may also affect oxidation behavior. 


\section{Bibliography}

1. U, R. Evans, The Corrosion and Oxidation of Metals, Arnold Publishers, London, 1968; First Supplemental Volume, 1976; Second Supplemental Volume, 1961.

2. R. Rapp (cd.), High Temperature Corrosion, National Association of Corrosion Engineers, Houston, Texas, 1983.

3. P. Kofstad, High Temperature Oxidation of Metals, John Wiley and Sons, New York, New York, 1966.

4. K. Hauffe, Oxidation of Metals, Plenum Press, New York, New York, 1965. 


\subsubsection{Aqueous Corrosion}

HLW, particularly if emplaced at sufficiently high temperatures in an unsaturated medium, will tend to dry out the geologic medium near the waste package. As the heat generated by the waste decays, the medium proximal to the waste package will re-wet to some degree. Additionally, at times before significant decay of heat from the waste package, liquid water may be introduced onto the waste package as a result of gravity drainage of water, from above the waste package, which had been suspended there by virtue of the heat-pipe effect. After that time, the container degradation will be influenced by corrosion in the aqueous phase if water intrudes the repository. In a saturated repository, the container may be always wet even during the early part of the canister life in the repository, when the temperature is atrove the bolling point of water. As such, the container may start degrading due to aqueous corrosion miuch earlier, if the repository were saturated, as opposed to unsaturated. Depending, among other factors, on (1) the chemical species present in the aqueous phase, (2) the geometry of the container and its surface flaws, (3) crevices in the waste package, (4) properties of the oxide layer already present on the container, and (5) rupture and regenerative characteristics of the surface oxide films, the waste-package material could degrade via one or more forms of corrosion.

The degradation of a metallic material due to corrosion can be broadly classifted into two types, uniform and localized corrosion, depending primarlly on the appearance of the corroded metal. For the waste-package components, both types need to be considered. The emphasis will depend on whether the material chosen is classified as a corrosion "allowance" or "resistant" material. The specific types of corrosion considered most relevant to the HLW repository environment are: uniform, pitting, crevice, galvanic, dealloying (selective leaching), and stress corrosion cracking. These forms of corrosion and their potential for an adverse impact on the waste-package materials are discussed in the following subsections. 'The host media for the repository could be salt, basalt, clay, granite, tuff, or some other deposits. Each of these media may present some additional or unique corrosion problems, which will have to be dealt with in the licensing application for a specific geologic repository. 


\section{Statement}

Uniform (or general) corrosion is characterized by a chemical or electrochemical reaction that proceeds uniformly over the entire exposed surface. This is the most common form of metal wastage phenomenon in aqueous environments.

\section{Concern}

If corrosion "allowance" materials are used for the waste package as opposed to corrosion "resistant" materials, the designers may account for a high corrosion rate of these materials in too simplistic a manner. For example, the designer nuay just increase the thickness of the container to ensure that a complete loss of the wall will not occur through aqueous corrosion during the containment period, but may fail to consider additional concerns that may be a direct result of the use of corrosion "allowance" materials.

Basis

Sometimes, designers erroneously believe that it is easier to design an engineering component, for service in a corrosive environment, with a corrosion "allowance" material, than with a corrosion "resistant" material. This is perhaps because corrosion "allowance" materials degrade via a general or uniform corrosion mode, rather than through a localized accelerated attack. The point is sometimes argued that laboratory data for corrosion "allowance" materials can be used ( $c$ nservatively) by designers, by assuming the constant rate of corrosion observed in short-term tests. General or uniform corrosion rates can be predicted with greater confidence than localized attacks, e.g., pitting or crevice attacks, which are statistical in nature and quite often unpredictable in terms of the location and severity of the attack.

The use of corrosion "allowance" materials for the waste-package components, however, needs thorough evaluation of additional concerns that will be raised by virtue of using such materials. For example, because of their higher general corrosion rate, the generation of greater concentrations of corrosion products may have a more significant impact on the surrounding environment than that resulting from the use of corrosion "resistant" materials. Should the corrosion "allowance" material contain alloying elements or impurities that provide favorable culture environments for microbes detrimental to the metal corrosion resistance, e.g., sulfur and sulfur compounds, the microbial activities become increasingly important.

Again, due to higher corrosion rates of corrosion "allowance" materials, the canister has to be made more robust (thicker), which could lead to concerns related to metal creep. The creep rate could be influenced by the self-weight of the canister during the early part of the canister life in the repository, and due to lithostatic or hydrostatic loading during the later part of the canister life, when it has thinned substantially, due to high corrosion rate.

Another concern with the use of corrosion "allowance" materials is the higher volume of corrosion products that will be generated, some of which may contain activated elements. These corrosion products could migrate away from the canister, to the "accessible" environment, even when the waste package is providing complete containment for its radioactive contents. 
1. U. R. Evans, The Corrosion and Oxidation of Metals Arnold Publishers, London, 1968; First Supplemental Volume, 1976; Second Supplemental Volume, 1961.

2. L. L. Shreir, Corrosion, Newnes-Butterworth Publishers, London, 1976.

3. M. Fontana, Corrosion Engineering, McGraw-Hill Publishing Company, New York, New York, 1988. 
Localized corrosion is generally associated with metals that exhibit a phenomena called "passivity." Passivity refers to the loss of chemical reactivity under certain environmental conditions. In effect, certain metals or alloys may become essentially inert and act as if they were noble metals. On the other hand, if certain conditions exist, these metals show localized accelerated attacks that far exceed the general ir uniform corrosion observed in these metals. Such characteristics of the waste-package component materials, if not recognized and addressed, could lead to premature failure of the waste-paclage components. In some cases, the failures could be significant relative to the performance requirements. The localized attacks usually manifest themselves in the form of breakdown of the passive or protective surface film, which is usually an oxide. The occurrence, intensity, and location of these localized attacks are somewhat random in nature and cannot be easily predicted. This section of the report describes some of the types of localized accelerated corrosion attack that could occur in HLW package components in a geological repository. These, therefore, need to be considered appropriately in the process of materials selection for the waste-package components. 


\subsection{2b.1 Galvanic Corrosion}

\section{Statement}

Galvanic corrosion results from electrical effects generated by dissimilar metallic materials in contact with each other in an electrolyte.

\section{Concern}

Incompatibility of materials for the various components of the engineered barrier systern (EBS) could lead to unfavorable galvanic corrosion of waste-package components. Optimization of construction materials for various components independently could lead to the EBS being susceptible to unfavorable galvanic corrosion of its components, particularly the container.

Basis

The EBS will include several components, such as borehole liner, container, pour canister (Type 304L stainless steel containing vitrified waste), fucl rods (mainly zirconium alloys or stainless steels), Zircaloy fuel channels for BWR, and other fuel assembly componenis mainly made of stainless steels or alloys containing relatively high amounts of nickel and chromium. Although some freedom exists in selecting materials for the borehole liner, container, support plate, and emplacement dolly, there is no freedom of choice for materials for some other components; or the choice has already been made before the selection of material for the container, such as fuel cladding and pour canister. (According to present plans, most if not all of the existing, reprocessed HLW will have been vitrified and poured into Type 304L stainless steel canisters several years before any repository is licensed.)

In the event of liquid intrusion into the repository, galvanic corrosion of the container may occur unless the EBS components are optimized. Thus, in addition to other considerations, the HLW container material will have to be cathodic to other components of the EBS system. The aqueous environment in which the galvanic corrosion might occur may be complex and include (1) corrosion products from various EBS components, (2) radiolysis products from air and water vapor in the repository, and (3) leached minerals from the repository geologic media. The liquids present in the borehole may be concentrated by localized boiling on the container surface. In such a complex electrolyte, components normally anodic in pure water may exhibit cathodic behavior. Such a change in the electrochemical behavior of metals, from anodic to cathodic polarization, has been observed in some varieties of stainless steels, such as Types 304 and 316, when a galvanic cell is set up with copper or copper alloys in different electrolytes.

The HLW container would be susceptible to galvanic corrosion attack in both the vertical and horizontal emplacement configuration of the waste package. Therefore, assurance is necessary that the container material will not act as a sacrificial anode during its life in the repository or that such a behavior is predictable and can be factored into the container design. Additionally, galvanic corrosion may be a possibility in the internal environment of the container. 


\section{Bibliography}

1. American Society for Metals Committee on Corrosion of Copper, N. W. Polan, Chairman, "Corrosion of Copper and Copper Alloys," in Metals Handbook, 13, Corrosion, 9th ed., ASM International, Metals Park, Ohio, 1987.

2. $\quad$ L. L. Shreir (ed.), Corrosion, Newnes-Butterworths Publishers, London, 1976.

3. H. P. Hack (ed.), Galvanic Corrosion, ASTM Special Technical Publication No. 978, American Society for Testing and Materials, Philadelphia, Pennsylvania, 1988. 


\section{Statement}

Most engineering materials show a form of localized attack, commonly referred to as pitting, under some specific environment combined with specific surface conditions or alloy chemistry. The characteristics and kinetics of pit initiation, growth, and repassivation are quite different in different types of materials. If the geometry and local environment in the pit are not conducive to repassivation, then kinetics of pit growth may be an important factor in determining the container life in a repository.

\section{Concern}

Pitting of a material surface is soinewhat random in the location of the attack and may or may not occur on a particular metal sampic. Localized pitting can be severe when uniform corrosion is minor, and it may be erroneously accounted for by factoring it into the calculation of "uniform" corrosion rate.

Basis

A chloride environment may lead to pitting in some materials that depend on a surface passivation layer to provide corrosion protection, such as in commonly used stainless steels. Surface pitting is not frequently observed in copper/copper-based alloys that do not depend so strongly on surface oxide for corrosion resistance. In copper and copper-based alloys, corrosion pits tend to be shallow and have been reported to reach a small finite depth beyond which they do not grow. The kinetics of the nucleation and growth of pits are expected to be related to a number of factors, including inclusions, surface flaws and finish, general service environment, and localized environment in the vicinity of the pit.

Without a detailed understanding of the causes leading to localized pitting, and the kinetics of growth and repassivation (if any) of a pit, accounting for this localized but accelerated degradation mode would be impossible. The lack of understanding of the pitting phenomena will also reduce the ability to predict susceptibility of the material to pitting after a long incubation period. Use of a material with known susceptibility to pitting for components of a waste package requires a scientific understanding of the causes of pitting and the kinetics of the nucleation and growth of the pits. These corrosion kinetics will have to be considered in the waste package design, if the goal of long-term isolation of HLW in a repository is to be achieved.

\section{Bibliography}

1. Z. Szklarska-Smialowska, Pitting Corrosion of Metals. National Association of Corrosion Engineers, Houston, Texas, 1986.

2. R. W. Staehle, et al., (eds.), Localized Corrosion, National Association of Corrosion Engineers, Houston, Texas, 1974.

3. V. F. Lucey, "Mechanism of Pitting Corrosion of Copper in Supply Water, "Br. Corrosion J., 2. p. $175,1967$.

4. V. F. Lucey, "Developments Leading to the Present Understanding of the Mechanism of Pitting Corrosion of Copper," Br. Corrosion J., 7, p. 36, 1972.

5. A. J. Sedriks, Corrosion of Stainless Steels, John Wiley and Sons, New York, New York, 1979. 


\subsection{2b.3 Crevice Corrosion}

\section{Statement}

Crevice corrosion (sometimes regarded as a special case of pitting corrosion) can occur near crevices formed by either two metal surfaces or a metal and a nonmetal surface.

\section{Concern}

The sites for crevice corrosion on a HLW container may be unavoidable because of structural or functional design and also may arise during the exposure period in a geologic repository. The likely locations of large crevices include the container bottom-support plate interface (vertical emplacement configuration), container wall-dolly contact surfaces (horizontal emplacement configuration), and container wall-backfill interface (if backfill is used in the borehole, e.g., bentonite clay). Examples of other sites include spot-weld lap joints; threaded or riveted connections; presence of foreign objects or debris, such as dirt; or even accumulation of corrosion products derived from the canister material itself.

Basis

Crevice corrosion attack can sometimes be controlled by in-service cleaning of the surface. For example, condensers and heat exchangers are cleaned periodically to prevent deposit attack. Such a cleaning process, obviously, is not possible for the HLW package components after emplacement in a sealed geological repository. Therefore, if the material selected for a waste-package component is susceptible to a higher crevice corrosion rate in a repository environment than the general corrosion rate, then the design and performance analyses have to consider the kinetics of crevice corrosion.

These analyses require (1) a thorough understanding of the conditions under which crevice corrosion occurs, and (2) a knowledge of the local environment in and around the crevice that is likely to occur during the entire period the canister must provide containment. The emplacement configuration of the waste package in the repository must be considered, as it could influence the intensity of the crevice corrosion. For example, both the likelihood of crevice corrosion attack and the severity can increase if the area within a crevice is small compared to the area outside the crevice. An alternative design with less likelihood of crevice corrosion occurring would avoid tight crevices.

Other conditions that would increase the likelihood of crevice corrosion are higher water temperature or a flow condition on the surface outside the crevice. Because of the nature of the waste forms, HLW containers with spent fuel are expected to be at a higher temperature than those containing vitrified waste, for at least the first 1000 years. However, in the event of water intrusion in the repository during the containment period, the flow conditions could be of greater concern to the containers with vitrified waste form than those with spent fuel (assuming a limited amount of water penetrates the borehole on a continuing basis). Such scenarios must be developed carefully and considered when designing containers both for vitrified and spent-fuel waste forms. 


\section{Bibliograpiny}

1. I. L. Rosenfeld, "Crevice Corrosion," p. 373, in Localized Corrosion, National Association of Corrosion Engineers, Houston, Texas, 1974.

2. W. D. France, "Crevice Corrosion," p. 164, in Localized Corrosion -- Cause of Metal Failure, American Society for Testing and Materials, Philadelphia, Pennsylvania, 1972.

3. J. W. Oldfield and W. H. Sutton, "Crevice Corrosion of Stainless Steel. II - Experimental Studies," Br. Corrosion J., 13, p. 104, 1973.

4. R. J. Brigham, "Temperature as a Crevice Corrosion Criterion," Corrosion, 30, p. 396, 1974.

5. A. J. Sedriks, Chapter 5 on "Crevice Corrosion," pp. 88-109, in Corrosion of Stainless Steel, John Wiley and Sons, New York, New York, 1979. 


\subsection{2b.4 Stress Corrosion Cracking}

Statement

Stress Corrosion Cracking has been shown to occur in gaseous, vapor, and aqueous media. Therefore, modeling of the failure mechanisms of a material should consider all three different environments, in particular, the effect of a transition between dry and moist air, or from a gaseous to a liquid phase in the repository.

\section{Concern}

The mechanism of stress corrosion cracking is not completely understood, and more than one mechanism may be capable of causing crack initiation followed by propagation. Premature failure may result from crack propagation, due to chemical and mechanical interactions between the material and its environment.

Basis

The commonly stated assumption that stress corrosion cracking results from anodic dissolution and removal of metal from the crack tip is not universally accepted, particularly for transgranular stress corrosion cracking. Furthermore, not all viable mechanisms require a liquid phase at the crack tip. For example, in addition to the film rupture anodic dissolution model, three alternative mechanisms for transgranular stress corrosion cracking of stainless steels have been proposed: hydrogen embrittlement, film-induced cleavage, and surface diffusion. These mechanisms do not always require liquid-phase water at the crack tip. If a liquid phase is not required at the crack tip for environmentally induced cracking, then cracking may be possible in the unsaturated zone during the containment period. The changing nature of the environment should be considered, too. The transition from a dry to a wet condition and reverse may accelerate crack initiation and growth. Therefore, an evaluation of stress corrosion cracking resistance of candidate container materials in all three phases should be made, i.e., in gaseous, vapor, and liquid phases. Additionally, episodic intrusion of water may occur, resulting in alternate wetting and drying of the waste package, making it necessary to study the effects of such conditions.

\section{Bibliography}

1. D. Parkner and I. M. Bernstein (eds.), Handbook of Stainless Steels, McGraw-Hill, New York, New York, 1977.

2. R. N. Parkins, "Stress Corrosion Spectrum," Br. Corrosion J., 7, p. 15, 1972.

3. P. R. Swan, F. P. Ford and A. R. C. Westwood (eds.), Mcchanisms of Environment Sensitive Cracking of Materials, The Metals Society, London, 1977.

4. J. C. Scully, "Stress Corrosion Cracking," p. 103 in Treatise on Materials Science and Technology, 23, Corrosion: Aqueous Processes and Passive Films, Academic Press, London, 1983.

5. F. P. Ford, "Stress Corrosion Cracking in Iron-Base Alloys," p. 235 in Treatise on Materials Science and Technology 25, Embrittlement of Engineering Alloys, Academic Press, London, 1983. 
6. E. N. Pugh, "Progress Towards Understanding the Stress Corrosion Problem," Corrosion, 41. p. 517, 1985.

7. R. W. Staehle, et al., (eds.), Stress Corrosion Cracking and Hydrogen Embrittlement of Iron-Base Alloys National Association of Corrosion Engineers, Houston, Texas, 1977. 


\subsection{2b.5 Dealloying}

Statement

In some alloys, dealloying or selective leaching of one component of the alloy can occur. This phenomenon generally leads to considerable loss in the mechanical strength of the component and, in extreme cases, partial or complete loss of containment.

\section{Concern}

The rate of dealloying attack can be quite rapid. Therefore, if water intrudes into the repository, substantial damage to the waste-package components could occur in a rather short time, when compared with times for other likely modes of degradation. The dealloying mode of materials degradation has no standard method for evaluation.

Basis

One mechanism for dealloying is the selective dissolution of one element, leaving behind a residual mass of the other element. Another more commonly accepted mechanism involves the simultaneous dissolution of the principal alloying elements, followed by a subsequent redeposition or precipitation of one alloying element (usually the major constituent), at favorable sites. (Some observers conclude that both mechanisms could exist simultaneously, depending on various external influences. Others conclude that selective removal of one constituent may serve as a starting mechanism, creating favorable sites for the subsequent deposition of one of the elements after the alloy dissolves as an entity.) Although neither mechanism appears to adequately explain all observations reported so far, no other truly different explanation of dealloying exists.

Some binary alloys of copper are prone to dealloying (selective leaching) under certain conditions. For example, copper-aluminum alloys, particularly those with more than eight percent aluminum, have failed in this mode. The intensity of the failure mechanism is especially severe in alloys with a continuous gamma-phase and usually occurs as plug-type dealloying. No effective minor alloying additions are known for aluminum bronzes, but heat treatment offers some success in limiting delamination-type dealloying. Dealloying of nickel in copper-nickel alloys, although rare, has been observed at temperatures over $100^{\circ} \mathrm{C}$, low-flow conditions, and high local heat flux. Such conditions could occur over the long period during which the waste package is required to provide containment.

If alloys susceptible to dealloying mode of degradation are chosen for the waste-package components, a demonstration that dealloying phenomena will not lead to premature failure of the waste package in a repository environment is required.

\section{Bibliography}

1. K. Kaesche, Metallic Corrosion, National Association of Corrosion Engineers, Houston, Texas, pp. 194, 1985.

2. H. Leidheiser, The Corrosion of Copper, Tin, and Their Alloys, John Wiley and Sons, New York, New York, 1971.

3. H. W. Pickering, "Characteristic Features of Alloy Polarization Curves," Corrosion Sci., $\underline{23}$ p. $1107,1983$. 


\subsubsection{Hydrogen Embrittlement}

\section{Statement}

Some materials, including many ferritic steels, are susceptible to embrittlement or damage as a result of hydrogen absorption from various sources.

\section{Concern}

Insufficient understanding of the effects of hydrogen on the components of a waste package could lead to premature failures, due to hydrogen damage or embrittlement. Long-term behavior may differ from that predicted on the basis of short-term tests.

Basis

Hydrogen is almost always present in most engineering materials. The scuurces of hydrogen are many and varied, including metal refining processes, hydrogenous impurities, and fabrication processes such as welding and acid pickling. The external sources of hydrogen in a geologic repository environment are atomic hydrogen generated by reduction of water due to aqueous corrosion of the metallic containers, and by radiolysis of water or water vapor due to the gamma radiation field arising from the radioactive waste.

Hydrogen interacts with metals and alloys in many ways and, as a consequence, can be present in different metals in various forms, as listed below:

(1) adsorbed hydrogen on surfaces of materials;

(2) atomic hydrogen in solid solution;

(3) molecular hydrogen in vold spaces within the metal;

(4) hydrogen as a component of methane gas formed after reaction with carbon in the metal;

(5) hydrogen as a hydride.

The effects of these interactions are numerous, and almost none of them improves the properties of the affected materials. For example, hydrogen attack of steels results in (1) surface depletion of carbon, which alters mechanical properties (usually decreases the strength level), and (2) formation of methane, which has an embrittling effect by decreasing the ductility. Hydrogen forms hydrides in metals like titanium and zirconium, resulting in embrittlement.

Hydrogen embrittlement, arising from adsorption and absorption of atomic hydrogen, can cause a loss of ductility (failure at lower values of true stress and true strain), as well as crack initiation and propagation at values of the stress-intensity factor much lower than those of the unembrittled material.

Although a large body of technical information is available on the hydrogen-metal interactions over a wide range of temperatures, less is known about these interactions under conditions that may prevail in a repository, such as very long times at moderately elevated temperatures $\left(100-300^{\circ} \mathrm{C}\right)$ and relatively high gamma radiation levels. 
1. R. A. Oriani, J. P. Hirth, and M. Smialowskd (eds.), Hydrogen Degradation of Ferrous Alloys, Noyes Publications, Park Ridge, Illinois, 1985.

2. A. W. Thomson and I. M. Bernstein (eds.), Effect of Hydrogen on Behavior of Metals, The Metallurgical Society of the American Institute of Mining, Metallurgical and Petroleum Engineers, Now York, New York, 1976.

3. C. G. Interrante and G. M. Pressouyre (eds.), Current Solutions to Hydrogen Problems in Sicels ASM International, Metals Park, Ohio, 1982.

4. D. L. Johnson and D. A. Davis, "Lffect of Sensitization on Hydrogen Transport in Austenitic Stainless Steel," Scripta Metallurgica, 23, pp. 321-326, 1984. 


\subsubsection{Mechanical Effects}

\section{Statement}

The time-dependent damage of components of a waste package may be brought about by the presence of loads or strains imposed from sources within or outside of the waste package.

\section{Concern}

The principal mechanical concerns for waste-package components are thelr reactions to loads arising from environmental influences such as those from tectonic and seismic activities and from lithostatic or hydrostatic forces. Other potential sources of loads are those from thermal and radiation effects and from the presence of reaction products causing a wedging effect.

Basis

Alteration of the stress state of a diffusion barricr, like bentonite backfill, could alter the characteristics of the barrier and affect performance perhaps by alteration of permeation rates, adsorpinn coefficients, etc. In the case of HLW containers, mechanical damage could be caused by hydrostatic or lithostatic pressures; fallen rocks; unusual seismic events; internal pressure from reactions of the contents; or a constrained displacement loads, as for example when a material expands or contracts due to thermal or radiation effects. Some examples are (1) hydrostatic pressure that would be expected to be applied to a container in a repository situated below the water table, (2) axial load that could be imposed on a borehole liner, and (3) constrained displacement between container material and glass waste form, or between container material and its corrosion products. These various sources of stress may promote container failure by yielding, ductile rupturing, and altering the rate at which crack initiation or propagation accurs in a material. It should be noted that reduction of wall thickness, as a result of uniform corrosion, will increase the stress for a given load.

A constrained displacement load arises when the natural tendency of a material to expand or contract is constrained by a neighboring material. Three examples of natural expansion are (1) thermal expansion/contraction of a material due to change in temperature, (2) volume change of vitrified HLW caused by exposure to a gamma radiation field, and (3) differential change in volume between a metal and its corrosion products. Thermal fatigue is an example of the adverse effect of a rapid change in temperature resulting in constrained expansion and contraction. In the case of HLW containers, thermal fatigue may be caused by the evaporation of water, condensation near the top of borehole, and subsequent falling of water droplets onto the hot container. Although the temperature differentials in this case would be expected to be relatively low, the long service life required may make thermal fatigue a significant damage mechanism.

Long-term direct damage caused by various sources of stress may be difficult to assess. For example, in short-term tests, creep may not take place in the presence of these stresses at moderately elevated temperatures. However, the possibility of creep in HLW containers can not be eliminated over an extended period of time. The deformation and fracture mechanism maps can be applied to predict, in general terms, the dominant mechanism of deformation and failure for different materials. For example, copper with a relatively low yield strength and low-homologous temperatures under the repository thermal conditions can be expected to undergo creep at rates sufficiently high $\left(-10^{-6} / \mathrm{s}\right)$ to be a concern over the repository lifetime. On the other hand, for AISI 316 stainless steel, no significant creop would be expected. 
1. W. J. O'Conner and R. S. Drash, Waste Package Performance Assessment: Deterministic System Model Program Scope and Specification, Lawrence Livermore National Laboratory, Report No، UCRL53761, October 1986.

2. INTERA Environmental Consultants, Inc., WAPPA: A Waste Package Performance Assessment Code, Battelle Memorial Institute, Office of Nuclear Waste Isolation (ONWI), Report No, ONWI-452, 1983.

3. D. A. Spera and D. F. Mowbray (eds.), "Thermal Fatigue of Materials and Components," Proceedings of a Symposium, ASTM Special Technical Publication No. 612, 1976.

4. "Thermal and High-Strain Fatigue," Monograph and Report Series No. 32, The Metals and Metallurgy Trust of the Institute of Metals, London, 1967.

5. H. J. Frost and M. F. Ashby, Deformation Mechanism Mans--The Plasticity and Creep of Metals and Ceramics, Pergamon Press, New York, New York, 1982.

6. M. F. Ashby, C. Gandhi, and D. M. R. Taplin, Fracture Mechanism Maps and Their Construction for FCC Metals and Alloys, Acta Metallurgica, 27 p. 699, 1979. 


\subsubsection{Degradation of Other Barriers}

\section{Statement}

This report has emphasized the use of a metallic container, to satisfy the containment requirement of 10 CFR Part 60; there may be other barriers performing the same or complementary functions. Other barriers also may become altered over the extended periods of exposure required in repository service, as may the metallic barriers discussed in this report. The interactions between the materials used in these barriers and their environments, as well as the mechanisms of alteration, are specific to each material/environment system.

\section{Concern}

The level of understanding of the behavior of and the processes involved in any alterations that occur over extended times for these other barriers must be comparable with that described in this report, which focuses on the behavior of metallic containers. The absence of explicit examples of technical considerations that are specific to these other barriers may lead the license applicant to present arguments that would be regarded to be insufficient.

Basis

In the work done worldwide to date on the disposal of HLW, various types of containers for radionuclides are being explored. Although the functions of these various containers may differ among the various national programs that could be cited, the principal materials being explored are, almost without exception, metallic. In the U.S. effort, the Yucca Mountain Project is exploring the suitability of each of six commercially available metal alloys as candidates for a containment barrier that could satisfy the 300- to 1000-year containment requirement. Nevertheless, it is conceivable that other solutions to this problem may prove to be effective, and alternatives should be considered, either as a principal barrier or as a supplemental barrier in a conservative, multi-barrier system.

The requirement in the U.S. is for containment of all radionuclides within the waste package. A metallic barrier is impervious to all radionuclides of interest, including gaseous species. Further, metals have a long history as pressure vessels, with an outstanding service record attributable, in part to organizations like the Pressure Vessel Research Committee. Thus, metallic containers have been chosen as candidate barrier materials for this application. This is so despite the fact that some small amount of radiation may be leachable from the surface of a metallic container, c.g., ${ }^{14} \mathrm{C}$, which is radioactive and may form during the containment period. The process that limits escape of radionuclides is corrosion of the metal, so a metallic container could be considered to be a corrosion barrier. In the field of materials science, the behavior of metals has been more extensively studied than other candidate barrier materials. Therefore, one might expect that, on a relative basis, the materials community would have as much or more scientific understanding of systems involving metallics, when compared with other barrier systems.

Other barrier systems to be considered for this application in materials engineering include leaching barriers, transport barriers, and adsorption barriers. The function of the waste package is to prevent the transport of radionuclides to the boundary of the waste package, and this must be done not only for radionuclides that exist as solids but also for any gaseous waste form. Further, if the container/environment system has a potential for buildup of gaseous pressure inside of the container, then fracture and the pressure-vessel characteristics of these other barrier systems become important considerations. The key point that this report is intended to convey, in relation to other barrier systems, is that the level of detailed understanding of the behavior of these systems must be comparable to that presented here for the metallic barriers. 
In a leaching barrier, one could conceive of, for example, vitrified HLW that is in the form of logs or pellets; if this waste form could be coated with a material that isolates the waste form from the environment of the waste package, it could satisfy the containment requirement. In this example, the process that limits the life of the barrier is leaching of this coating. This barrier would have to prevent escape of radionuclides through the coating. It would have to (1) prevent (or limit) transport through the coating and (2) have an adequately low leachability so as to survive the containment period. In addition, it must not fracture, as this would expose radionuclides to the waste-package environment, and it must not degrade by any other mechanism, e.g., oxidation, spalling, etc., that would shorten its service life.

Transport and adsorption types of barriers must possess the property of low permeability for the waste form. Clays and rock-like materials are representative examples of these two classes of barriers. These barriers derive their ability to contain radionuclides from two properties: (1) low permeability for all forms of the contained radionuclides, and (2) a high capacily for the chemisorption of the species $n f$ interest. An important consideration is that the exposure to repository conditions does not enhance permeability by altering pore spacing, interconnectivity of pores, etc. In addition, it should be noted that the presence of this type of barrier, as a supplement to a metallic container, could have a detrimental effect on the performance of the metallic container. For example, bentonite as a packing material in contact with a metallic container may promote crevice corrosion. 


\subsection{Inspections and Monitoring}

Inspection criteria should be developed and reports should be used over the entire preclosure lifecycle of a component of a waste package, to ensure and confirm that components meet design requirements. Through in-situ measurements, these criteria and reports also serve to confirm that environmental conditions and behavior in service are consistent with predictions from models and tests.

Through as long a period as is practical in the life cycle of a repository, inspections of wastepackage components and of environmental conditions are needed. Inspections of components should occur in the prociuction of waste packages and their components. As waste packages are being produced, inspections should be used to ensure that the components are fabricated and emplaced in compliance with the design specifications. During the service period, the in-service behavior can be compared with modeling predictions used to develop waste-package designs, so that any inconsistencies can be evaluated. Inspections for the environment should be extended over a long period, starting at the time of site characterization. After enplacement, the role of inspections will be in the confirmation of the interactions between the waste package and the environment. The inspections should be used to compare the observed repository conditions to the expected conditions on which designs of components were based, so that differences can be noted and evaluated.

The repository environment is complex, and monitoring of the behavior of specimens and components placed into waste packages in the repository will improve understanding of the expected behavior for these components throughout actual service. The results of in-situ monitoring can be supplemented by the results of the monitoring program to be conducted at the geologic repository operations area, as called for in 10 CFR 60.143 , which involves laboratory tests that focus on the condition (especially the internal condition) of the waste packages. Together, these laboratory and in-situ tests can be used to furnish information needed to answer many of the questions that arise on both environmental conditions and the response and interactions to be expected in service.

Guidelines furnished in 10 CFR Part 60, indicate that there will be no openings to the surface of the repository after closure. Apparently, the notion is that closure will be made only after there is reasonable assurance that the predictions of behavior are accurate and therefore the public safety has been assured. Nevertheless, it is noted that, even with present-day technology, monitoring of various aspects of the condition of waste packages after closure of the repository could be performed without making openings to the surface. Telemetric methods could be adapted to provide information deemed useful for a second repository or for scientific purposes. At the time of repository closure, more sophisticated techniques are likely to be available for monitoring. 


\subsubsection{Inspections}

\section{Statement}

Inspection, in this section, is limited to activities involving inspection of the repository before emplacement, inspection of the containers onsite, and inspection of the containers after emplacement. These inspections are needed to ensure 1) that the observed repository conditions are similar to the expected conditions on which designs are based, and 2) that the components are produced and emplaced in compliance with the design specifications.

\section{Concerns}

If a proper system of inspections is not implemented, verification that the waste package is in compliance with the specifications and requirements cannot be assured.

\section{Basis}

In the establishment of the service requirements for a component of a waste package, the entire life cycle of the component must be considered. This includes the marerials as-received from the producer, the fabrication of components from these materials, and the transportation and emplacement of these components into a waste package. Inspection requirements before and after fabrication have been discussed in Section 3.2. compliance:

Several inspections are suggested for establishment of service requirements and to verify

(1) Inspection of the repository environment to establish or reaffirm its spacial and temporal variability, including hydrological stacks, the mineral content, and other data pertinent to the performance of a waste package.

(2) Inspection of the waste-package sites to determine site uniformity, stability, suitability for intended service, and any release of the radioactive inventory.

(3) Inspection of waste-package components to ensure that (a) they were received, assembled, and emplaced properly, and (b) they are retrievable.

Once the waste package is emplaced and the initial emplacement conditions are found to be acceptable through various inspections procedures, further evaluation of the waste-package performance may be made by appropriate remote-monitoring techniques. 


\subsubsection{In-Situ Monitoring}

\section{Statement}

Preclosure monitoring will improve understanding of the actual service behavior of waste-package components vis-a-vis their anticipated behavior.

\section{Concern}

Predictions based solely on results of literature studies, out-of-repository tests, modeling, and expert opinions may be unrealistic and nonconservative.

Basis

Uncertainties can be resolved during the preclosure period. Monitoring up to the time of permanent closure is called for in 10 CFR 60.143(d) [Ref. 1]. It would be prudent to obtain data on the response of the HLW package and its components under actual service; this could be done for the entire time that the repository is still open and as long as any significant uncertainties remain in relation to the requirements for containment of the HLW.

Predictions of the behavior of components of a waste package should be made on the basis of scientific arguments that are supported by validated test data that are used to prepare a license application for disposal of HLW. Uncertainties in these arguments, as, for example, those related to mechanisms of degradation of waste-package components, can be resolved during the preclosure period. In-situ monitoring may play an important role in resolving these uncertainties and can also be used to confirm the tentative conclusions of predictive models.

The repository environment will be complex, with attendant uncertainties related to geological, bacteriological, climatological, volcanotectonic, and hydrological changes that might take place over the service life and beyond. Although it will be impossible to account for all possible effects that could occur in a repository for the entire duration of the containment period, it would be prudent to obtain data on the response of the HLW package and its components under actual service; this could be done for the entire time that the repository is still open and as long as any significant uncertainties remain in relation to the requirements for containment of the HLW. The containers are subject to retrievability for a period beginning up to 50 years after the start of emplacement operations at the repository. Although it would be difficult to simulate the thermal conditions, the effects of radiation would be representative, and monitoring may provide information about the waste-package behavior. Monitoring may be performed by a variety of techniques, such as remote optical techniques, nondestructive examination, and electrochemical methods that should be adapted for the repository conditions.

\section{Reference}

1. U.S. Code of Federal Regulations, "Monitoring and Testing of Waste Package," Part 60, Chapter I, Title 10, "Energy." (Attached as Appendix B to this report.) 


\section{SUMMARY}

An important requisite in the overall demonstration of compliance with 10 CFR 60.113 is the need to demonstrate adequacy of assessments and predictions of the long-term performance of components of HLW packages that are proposed for use within the engineered barrier system in permanent geoiogic repositories. An additional requisite in a demonstration of compliance is that all technical considerations supporting the assessments and predictions must have a sound scientific basis. Once built, a repository is expected to provide permanent disposal and isolation of radioactive wastes. Based on 10 CFR Part 60 requirements, containment-related behavior of waste package components must be understood well enough to predict performance over a period of 300 to 1000 years. Thus, mechanistic understandings of the physical and chemical processes involved in the alteration of components with time are important to a successful waste-package design.

This report has attempted to present, in a systematic and structured manner, the higher-order technical considerations pertinent to evaluating waste-package containment performance. These considerations include technical aspects of the geological repository environment and the change in the environment over long periods of time, materials for the waste-package components, waste-package materials/repository environment interactions, materials and fabrication process specifications and inspections, as well as onsite inspections and in-situ monitoring. These considerations provide the technical basis for the further development of quantitative criteria for "substantially complete containment." The considerations identified are intentionally of higher-order; they do not specifically identify the tests or data generation, reduction, or analyses techniques that are required from a licensing point of view. Examples are provided to indicate some of the types of tests and techniques that could be considered relevant to the HLW package for a gaologic repository. 


\section{APPENDIX A}

\section{TERMINOLOGY}

\begin{tabular}{ll} 
Abbreviations & Term \\
\cline { 2 - 2 } ASME & American Society for Testing and Materials \\
ASTM & American Society of Mechanical Engineers \\
BWR & Boiling Water Reactor \\
CDM & Compliance Determination Method \\
CERT & Constant Extension Rate Test \\
CFR & Code of Federal Regulations (United States) \\
CNWRA & Center for Nuclear Waste Regulatory Analyses (SwRI) \\
DOE & Department of Energy (United States) \\
EBS & Engineered Barrier System \\
EPA & Environmental Protection Agency (United States) \\
GMAW & Gas Metal Arc Welding \\
GTAW & Gas Tungsten Arc Welding \\
HAZ & Heat Affected Zone (of a weldment) \\
HLW & High-Level (Radioactive) Waste \\
IGSCC & Intergranular Stress Corrosion Cracking \\
IR & Information Requirement \\
LWR & Light Water Reactor \\
NACE & National Association of Corrosion Engineers \\
NRC & Nuclear Regulatory Commission (United States) \\
PWR & Pressurized Water Reactor \\
REOP & Regulatory Element of Proof \\
RR & Regulatory Requirements \\
SCC & Stress Corrosion Cracking \\
SMAW & Shielded Metal Arc Welding \\
TRC & Technical Review Components \\
& \\
&
\end{tabular}

Definitions:

accelerated test ... a test that results in rates of alterations that are greater than the rates that occur in service.

alteration -- any change in the properties of a material.

alteration mechanism -- the fundamental chemical or physical processes by which alterations occur.

analog -- a natural material that is believed to be similar to a man-made material. The composition and history of environmental exposure of the analog are believed to be close enough so that observations of the analog can be used to infer behavior of the man-made material.

barrier -- any material or structure that prevents or substantially delays movement of water or radionuclides. [10 CFR 60.2] 
bounding calculation -- a calculation that uses bounding conditions for parameters that affect a process.

bounding condition -- the extreme credible value that might be expected for an independent variable.

characterization test -- in high-level radioactive waste, any test conducted principally to furnish information for a mechanistic understanding of degradation. Examples include polarization tests, solubility analyses, X-ray diffraction of corrosion layers, etc.

canister or pour canister -- the receptacle into which a vitrified waste form is poured. [10 CFR 60.2]

confirmation test -- in high-level radioactive waste management, a test that provides data that become available after a model has been validated. The test would normaliy be intended to provide confirmation data for the model predictions.

container -- an engineered barrier, usually of a metal or metal alloy, that is sealed and is designed to prevent both the release of its contents and any contact between its contents and the environment external to itseif. [10 CFR 60.2]

containment -- the confinement of radioactive waste within a designated boundary, [10 CFR 60.2]

degradation -- any change in the properties of a material that adversely affects the behavior of that material, i.e., an adverse alteration.

disposal -- the isolation of radioactive wastes from the accessible environment. [10 CFR 60.2]

empirical model -- a model based only on observations or data from experiments, without regard to mechanism or theory.

engineered barrier system -- the waste packages and the underground facility. [10 CFR 60.2]

geologic repository -- a system that is intended to be used for, or may be used for, the disposal of radioactive wastes in excavated geologic media. A geologic repository includes: (1) the geologic repository operations area, and (2) the portion of the geologic setting that provides isolation of the radioactive waste. [10 CFR 60.2$]$

geologic setting -- the geologic, hydrologic, and geochemical systems of the region in which a geologic repository operations area is or may be located. [10 CFR 60.2]

groundwater -- all water that occurs below the land surface. [10 CFR 60.2]

high-level radioactive waste or HLW -- (1) irradiated reactor fuel; (2) liquid wastes resulting from the operation of the first cycle solvent extraction system, or equivalent, and the concentrated wastes from subsequent extraction cycles, or equivalent, in a facility for reprocessing irradiated reactor fuel; and (3) solids into which such liquid wastes have been converted. [10 CFR 60.2]

in-service conditions -- the normal conditions to which a system and its components will be exposed during their operational lifetimes. [ASTM E722, E44]

in-service test -- a test in which building components or materials are exposed to degradation factors under in-service conditions. [E632, E6] 
mechanism -- the fundamental physical or chemical processes or sequence of processes involved in or responsible for an action, reaction, or other natural phenomenon.

mechanistic model -- a model based on one or more mechanisms.

model -- (1) a mathematical representation of a process; (2) a system of postulates, data, and inferences presented as a mathematical description of an entity or state of affairs [Webster]; (3) a simplified representation of a system or phenomena, with any hypotheses required to describe the system or explain the phenomenon, often mathematically [McGraw-Hill]; (4) a description or analogy used to help visualize something (as an atom) that cannot be directly observed [Webster].

performance confirmation -- the program of tests, experiments, and analyses that is conducted to evaluate the accuracy and adequacy of the information used to determine, with reasonable assurance, that the performance objectives for the period after permanent closure will be met. [10 CFR 60.2]

permanent closure -- final backfilling of the underground facility and the sealing of shafts and boreholes. [10 CFR 60.2]

retrieval - the act of intentionally removing radioactive waste from the underground location at which the waste had been previously emplaced for disposal. [10 CFR 60.2]

transuranic -- syn. transuranium element, an element with atomic number greater than 92 , and hence, an element beyond uranium in the periodic table. [ASTM]

vadose -- of, relating to, or being water or solutions in the earth's crust above the permanent groundwater level. [Webster]

waste form -- the radioactive waste materials and any encapsulating or stabilizing matrix. [10 CFR 60.2]

waste package -- the waste form and any containers, shielding, packing, and other absorbent materials immediately surrounding an individual waste container. [10 CFR 60.2] 


\section{APPENDIX B}

U, S. CODE OF FEDERAL REGULATIONS, 10 CFR PART 60, "DISPOSAL OF HIGH-LEVEL RADINACTIVE WASTES IN GEOLOGIC REPOSITORIES ${ }^{n}$ 


\section{PART 60-DISPOSAL OF HIGH-LEVEL RADIOACTIVE WASTES IN GEO. LOGIC REPOSITORIES}

\section{Subpart A-General Provisions}

Sec.

60.1 Purpose and scope.

60.2 Definitions.

60.3 License required.

60.4 Communications and records.

60.5 Interpretations.

60.6 Exemptions.

60.7 License not required for certain pre. liminary activities.

60.8 Reporting, recordkeeping, and applica. tion requirements: OMB approval not required.

60.9 Employment protection.

60.10 Completeness and accuracy of information.

\section{Subpart B-Licenses}

\section{Preapplication RevieW}

60.15 Site characterization.

60.16 Site characterization plan required.

60.17 Contents of site characterization plan.

60.18 Review of site characterization activities.

\section{LICENSE APPLICATIONS}

60.21 Content of application.

60.22 Filing and distribution of application.

60.23 Elimination of repetition.

60.24 Updating of application and environ. mental impact statement.

CONSTRUCtion AUthorization

60.31 Construction authorization.

60.32 Conditions of construction authorization.

60.33 Amendment of construction authorization.

LICENSE ISSUANCE AND AMENDMENT

60.41 Standards for issuance of a license.

60.42 Conditions of license.

60.43 License specification.

60.44 Changes, tests, and experiments.

60.45 Amendment of license.

60.46 Particular activities requiring license amendment.

\section{Permanent Closure}

60.51 License amendment for permanent closure.

60.52 Termination of license 


\section{Subpart C_-Participation by State \\ Governments and Affected Indian Tribes}

60.61 Provision of information.

60.62 Site review.

60.63 Particlpation in license reviews.

60.64 Notlce to States.

60.65 Representation.

\section{Subpart D-Records, Reports, Tests, and Inspections}

60.71 Records and reports.

60.72 Construction records.

60.73 Reports of deficiencies.

60.74 Tests.

60.75 Inspections.

\section{Subpart E-Technical Criteria}

60.101 Purpose and nuture of findings.

60.102 Concepts.

\section{Perfonmance Objectives}

60.111 Performance of the geologic reposl. tory operations area through permanent closure.

60.112 Overall system performance objec. tive for the geologic repository after per. manent closure.

60.113 Performance of particular barriers after permanent closure.

\section{LAND OWNERSHIP AND CONTROL}

60.121 Requirements for ownership and control interests in land.

\section{Siting Criteria}

60.122 Sitiug criteria.

\section{Design Criteria for the Geologrcal} REPOSITORY OPERATIONS AREA

60.130 Scope of design criteria for the geo. logic respository operations area.

60.131 General design criteria for the geologic repository operations area.

60.132 Additional design criteria for sur. face facilities in the geologic repository operations area.

60.133 Additional design criteria for the underground faciltty.

60.134 Design of seals for shafts and bore. holes.

\section{Design Criteria for the Waste Package}

60.135 Criteria for the waste package and its components.

Performance Confirmation Requiraments

60.137 General requirements for performance confirmation.

Subpart F-Performance Confirmation Program

60.140 General requirements.
(0).141 Confirmntlon of grotrehnical and dusiten paramoler's,

60.142 Design losting.

60.143 Monltoring and testing waste pack. ages.

\section{Subpart G-Quality Assurance}

60.150 Scope.

60.151 Applicabillty.

60.152 Implementation.

\section{Subpart H-Training and Certification of} Personnal

60.160 General requirements.

60.161 Training and certification program.

60.162 Physical requilrements.

\section{Subpart 1-Emergency Planning Criteria [Reserved]}

AuthortTy: Secs, 51, 53, 62, 63, 65, 81, 161, $182,183,68$ Stat, $929,930,932,933,935,948$, 953, 954, as amended (42 U.S.C. 2071, 2073, 2092, 2093, 2095, 2111, 2201, 2232, 2233); secs, 202, 206, 88 Stat. 1244, 1246 (42 U.S.C. 5842, 5846); secs, 10 and 14, Pub. L. 95-601, 92 Stat. 2951 (42 U.S.C. 2021a and 5851); sec. 102. Pub. L. 91-190, 83 Stat. 853 (42 U.S.C. 4332); secs, 114, 121, Pub. L. 97-425, 96 Stat. 2213, 2228, as amended (42 U.S.C. 10134, 10141).

For the purposes of sec. 223, 68 Stat. 958. as amended ( 42 U.S.C. 2273 ), $\$ \$ 60.10,60.7$ L to 60.75 are issued under sec. 1610,68 Stat. 950, as amended (42 U.S.C. 2201(0)).

Source: 46 FR 13980, Feb, 25, 1981, unless otherwise noted.

\section{Subpart A-General Provisions}

\subsection{Purpose and scope.}

This part prescribes rules governing the licensing of the U.S. Department of Energy to receive and possess source, special nuclear, and byproduct material at a geologic repository operations area sited, constructed, or operated in accordance with the Nuclear Waste Policy Act of 1982. This part does not apply to any activity licensed under another part of this chapter.

[51 FR 27162, July 30, 1986]

\subsection{Definitions.}

As used in this part:

"Accessible environment" means: (1) The atmosphere, (2) the land surface, (3) surface water, (4) oceans, and (5) the portion of the lithosphere that is outside the controlled area. 
"Affeoted Indian Tribe" means uxy Indian Tribe (1) within whose reserva. tion boundaries a repository for high. level radioactlve waste or spent fuel is proposed to be located; or (2) whose Federally defined possessory or usage rights to other lands outside of the reservation's boundaries arising out of Congressionally ratlfied treatles or other Federal law may be substantial. Iy and adversely affected by the locat. Ing of such a facillty; Provided, That the Secretary of the Interlor finds, upon the petition of the appropriate governmental offlcials of the Tribe, that such effects are both substantial and adverse to the Tribe.

"Anticlpated processes and events" means those natural processes and events that are reasonably likely to occur during the perlod the intended performance objective must be achieved. To the extent reasonable in the light of the geologic record, it shall be assumed that those processes operating in the geologic setting during the Quaternary Period continue to operate but with the perturbations caused by the presence of em. placi?d radioactive waste superimposed thereon.

"Barrier" means any material or structure that prevents or substantially delays movement of water or ra. dionuclides.

"Candidate area" means a geologic and hydrologic system within which a geologic repository may be located.

"Commencement of construction" means clearing of land, surface or subsurface excavation, or other substan. tial action that would adversely affect the environment of a site, but does not include changes desirable for the tem. porary use of the land for public recreational uses, site characterization ac. tivities, other preconstruction moni. toring and investigation necessary to establish background information re. lated to the suitability of a site or to the protection of environmental values, or procurement or manufacture of components of the geologic re. pository operations area.

"Commission" means the Nuclear Regulatory Commission or its duly au. thorized representatives.
"Contalnment" means the confinement of radioactlve waste within a des. Ignated boundary.

"Controlled area" means a surface location, to be marked by suitable monuments, extending horizontally no more than 10 kilometers in any direc. tion irom the outer boundary of the underground facllity, and the underly. ing subsurface, which area has been committed to use as a geologic repository and from which incompatible activities would be restricted following permanent closure.

"Director" means the Director of the Nuclear Regulatory Commission's Office of Nuclear Materlal Safety and Safeguards.

"Disposal" means the isolation of ra. dloactlve wastes from the accessible environment.

"Disturbed zone" means that portion of the controlled area the physl. cal or chemlcal properties of which have changed as a result of under. ground facility construction or as a result of heat generated by the em. placed radioactive wastes such that the resultant change of properties may have a significant effect on the performance of the geologic repository.

"DOE" means the U.S. Department of Energy or its duly authorized repre. sentatives.

"Engineered barrier system" means the waste packages and the under. ground facllity.

"Geologic repository" means a system which is intended to be used for, or may be used for, the disposal of radioactive wastes in excavated geolog. ic media. A geologic repository in. cludes: (1) The geologic repository operations area, and (2) the portion of the geologic setting that provides isolation of the radioactive waste.

"Geologic repository operations area" means a high-level radioactive waste facility that is part of a geologic repository, including both surface and subsurface areas, where waste handling activities are conducted.

"Geologic setting" means the geolog. ic, hydrologic, and geochemical sys. tems of the region in which a geologic repository operations area is or may be located. 
"Groundwater" means all water whlch occurs below the land surface.

"High-level radioactive waste" or "HLW" means: (1) Irradlated reactor fuel, (2) llquid wastes resulting from the operation of the first cycle solvent extraction system, or equlvalent, and the concentrated wastes from subse. quent extraction cycles, or equivalent. In a facllity for reprocessing Irradlated reactor fuel, and (3) sollds into which such llquid wastes have been convert. ed.

"HLW facilty" means a facllity sub. joct to the licensing and related regu. latory authorlty of the Commission pursuant to Sections 202(3) and 202(4) of the Energy Reorganization Act of 1974 (88 Stat 1244).'

"Host rock" means the geologic medium in which the waste is em. placed.

"Important to safety." with reference to structures, systems, and components means those engineered struc. tures, systems, and components essential to the prevention or mitigation of an accident that could result in a radl. ation dose to the whole body, or any organ, of 0.5 rem or greater at or beyond the nearest boundary of the unrestricted area at any time until the completion of permanent closure.

"Isolation" means inhibiting the transport of radioactive material so that amounts and concentrations of this material entering the accessible environment will be kept within prescribed limits.

"Permanent closure" means fina! backfllling of the underground facllity and the sealing of shafts and boreholes.

"Performance confirmation" means the program of tests, experiments, and analyses which is conducted to evaluate the accuracy and adequacy of the information used to determine with

\footnotetext{
These are DOE "facllities used primarily for the recelpt and storage of high-level radloactive wastes resulting from activities 11 . censed under such Act [the Atomlc Energy Act]" and "Retrievable Surface Storage Fa. cllitles and other faclilties authorized for the express purpose of subsequent longterm storage of high-level radloactlve wastes generated by [DOE], which are not used for, or are part of, research and development actlvitles."
}

reasonable assurance that the per. formance objectives for the period after permanent closure will be met.

"Publlc Document Room" means the place at 2120 L Streot NW., Washing. ton, D.C., at which records of the Commission will ordinarlly be made avallable for public inspection and any other place, the location of which has been published in the Frderal Ragrs" TER, at which publlc records of the Cornmission pertaining to a partlcilar geologic repository are made avallable for public inspection.

"Radioactive waste" or "waste" means HLW and ather radionctive ma. terials other than HLW that are re. celved for emplacement in a geologic repository.

"Restricted area" means any area access to which is controlled by the 11. censee for purposes of protection of Individuals from exposure to radiation and radioactive materials. "Restricted area" shall not include any areas used as residentlal quarters, although a separate room or rooms in a residentlal bullding may be set apart as a restrict. ed area.

"Retrieval" means the act of inten. tionally removing radloactive waste from the underground location at whlch the waste had been prevlously emplaced for disposal.

"Saturated zone" means that part of the earth's crust beneath the regional water table in which all volds, large and small, are ldeally filled with water under pressure greater than atmos. pheric,

"Site" means the location of the con. trolled area.

"Site characterization" means the program of exploration and research, both in the laboratory and in the fleld, undertaken to establish the geologic conditions and the ranges of those pa. rameters of a particular site relevant to the procedures under this part. Site characterization includes borings, sur. face excavations, excavation of exploratory shafts, limlted subsurface lateral excavations and borings, and in situ testing at depth needed to determine the suitability of the site for a geologic repository, but does not include preliminary borings and geophysical testing needed to decide whether site 
characterization should be undertak. en.

"Unanticipated processes and events" means those processes and events affecting the geologic setting that are judged not to be reasonably llkely to occur during the perlod the intended performance objective must be achleved, but which are neverthe. less sufflciently credible to warrant consideration. Unanticlpated processes and events may be elther natural proc. esses or events or processes and events Initiated by human activities other than those actlvities llcensed under this part. Processes and events initiat. ed by human buctivitles may unly be found to be sufficlently credible to warrant consideration if it is assumed that: (1) The monuments provided for by this part are sufficlently perma. nent to serve their intended purpose; (2) the value to future generations of potentlal resources within the site can be assessed adequately under the ap. plicable provlsions of thls part: (3) an understanding of the nature of radio. activity, and an appreclation of its hazards, have been retalned in some functioning institutions; (4.) institutlons are able to assess rlsk and to take remedial action at a level of social organization and technologlcal competence equivalent to, or superior to, that which was applled in initlating the processes or events concerned; and (5) relevant records are preserved, and remain accessible, for several hundred years after permanent closure.

"Underground facillty" means the underground structure, including openings and backfill materlals, but excluding shafts, boreholes, and their seals.

"Unrestricted area" means any area, access to which is not controlled by the llcensee for purposes of protection of individuals from exposure to radiation and radioactive materials, and any area used for residential quarters.

"Unsaturated zone" means the zone between the land surface and the regional water table. Generally, fluid pressure in this zone is less than atmospheric pressure, and some of the voids may contain air or other gases at atmospherlc pressure. Beneath flooded areas or in perched water bodies the fluld pressure locally rnay be greater than atmospherlc.

"Waste form"means the racloactive waste materials and any encapsulating or stabllizing matrix.

"Waste package" means the waste form and any contalners, shlelding. packing and other absorbent materlals immediately surrounding an individual waste contalner.

"Water table" means that sunface in a groundwater body at which the water pressure is atmospheric.

[48 FR 28217, June 21, 1983, as amended at 50 FR 29647, July 22, 1985; 51 FR 27162, July 30, 1986; 63 FR 43421, Oct. 27, 1988]

\section{\$ 601.3 License required.}

(a) DOE shall not recelve or possess source, special nuclear, or byproduct material at a geologic repository operations area except as authorized by a llcense issued by the Commission pur. suant to this part.

(b) DOE shall not commence con. struction of a geologic repository operatlons area unless it has flled an appllcation with the Commission and has obtained construction authurization as provided in this part. Fallure to comply with this requirement' shall be grounds for denial of a license.

\subsection{Communications and records.}

(a) Except where otherwise speclfled, all communications and reports concerning the regulations in this part and applications filed under them should be addressed to the Director of Nuclear Material Safety and Safeguards, U.S. Nuclear Regulatory Commission, Washington, DC 20555. Communications reports, and applications may be dellvered in person at the Commission's offices at $2120 \mathrm{~L}$ Street NW., Washington DC, or 11555 Rockville Pike, Rockville, Maryland.

(b) Each record required by this part must be legible throughout the retention period speclfied by each Commission regulation. The record may be the original or a reproduced copy or a $\mathrm{mi}$. croform provided that the copy or $\mathrm{ml}$. croform is authenticated by authorized personnel and that the microform is capable of producing a clear copy throughout the required retention period. The record may also be stored 
in electronic media with the capability for producing legible, accurate, and complete records during the required retention period. Records such as letters, drawings, spccifications, must include all pertinent information such as stamps, initials, and simatures. The licensee shall maintain adequate safeguards against tampering with and loss of records.

[53 FR 19: Lay 27, 1988, as amencied at 53 F'R 434:. ห. 27, 1988]

$\$ 60.5$ Interpretations.

Except as specifically authorized by the Commission, in writing, no interpretation of the meaning of the regulations in this part by any officer or employee of the Commission other than a written interpretation by the General Counsel will be considered intung upon the Commission.

\section{\$ 60.6 Exemptions.}

The Commission may, upon application by DOE, any interested person, or upon its own initiative, grant such exemptions from the requirements of the regulations in this part as it determines are authorized by law, will not endanger life or property or the common defense and security, and are otherwise in the public interest.

$\$ 60.7$ License not required for certain preliminary activities.

The requirement for a license set forth in $\S 60.3(\mathrm{a})$ of this part is not applicable to the extent that DOE receives and possesses source, special nuclear, and byproduct material at a. geologic repository:

(a) For purposes of site characterization; or

(b) For use, during site characterization or construction, as components of radiographic, radiation monitoring, or similar equipment or instrumentation.

\section{\$60.8 Reporting, recordkeeping, and ap- plication requirements: OMB appreval not required.}

The information collection requirements contained in this part affect fewer than ten persons. Therefore, under section 3506(c)(5) of the Paper. work Reduction Act of 1980 (Pub. L. 96-511), OMB clearance is not re- quired for these information collection requirements.

[47 FR 13774, Apr. 1, 1982]

\section{\$60.9 Employee protection.}

(a) Discrimination by a Commission licensee, an applicant for a Commission license, or a contractor or subcontractor of a Commission licensee or applicant against an employee for engaging in certain protected activities is prohibited. Discrimination includes discharge and other actions that relate to compensation, terms, conditions, and privileges of employment. The protected activities are established in section 210 of the Energy Reorganization Act of 1974, as amended, and in genoral are related to the administration or enforcement of a requirement imposed under the Atomic Energy Act or the Energy Reorganization Act.

(1) The protected activities include but are not limited to:

(i) Providing the Commission information about possible violations of requirements imposed under either of the above statutes;

(ii) Requesting the Commission to institute action against his or her employer for the administration or enforcement of these requirements; or

(iii) Testifying in any Commission proceeding.

(2) These activities are protected even if no formal proceeding is actually initiated as a result of the employee assistance or participation.

(3) This section has no applicaton to any employee alleging discrimination prohibited by this sectior, who, acting without direction from his o: her employer (or the employer's agent), deliberately causes a violation of any requirement of the Energy Reorgani:tior Act of 1974, as amended, or ti.e Atomic Energy Act of 1954, as amended.

(b) Any employee wr' believes that he or she has been dis arged or otherwise discriminated .......st by any person for engaging in the protected activities specified in paragraph (a)(1) of this section may seek a remedy for the discharge or discrimination through an administrative proceeding in the Departrient of Labcr. The administrative proceeding must be initi- 
ated within 30 days after an alleged violation occurs by filing a complaint alleging the violation with the repaitment of Labor, Employment Standards Aliministration, Wage and Hour Division. The Department of Labor may oider reinstatement, back pay, and ccmpensutory damages.

(c) A violation "paragraph (a) of this section by ? ommission licensee, an applicant for a Commission license, or a contractor or subcontractor of a Commission licensee or applicant may be grounds for:

(1) Denial, revocation, or suspension of the license.

(2) Imposition of a civil penalty on the licensee or applicant.

(3) Other enforcement action.

(d) Actions taken by an employer, or others, which adversely affect an employee may be predicated upon nondiscriminatory grounds. The prohibition applies when the adverse action occurs because the employee has engaged in protected activities. An employee's engagement in protected activities does not automatically render him or her immune from discharge or discipline for legitimate reasons or from adverse action dictated by nonprohibited considerations.

(e) Each licensee and each applicant shall post Form NRC-3, "Notice to Employees," on its premises. Posting must be at locations sufficient to permit employees protected by this section to observe a copy on the way to or from their place of work. Premises must be posted not later than 30 days after an application is docketed and remain posted while the application is pending before the Commission, during the term of the license, and for $3^{n}$ days following license termination.

Note: Copies of Form NRC-3 may be obtained by writing to the Regional Administrator of the appropriate U.S. Nuclear Reg. ulatory Commission Regional Office listed in Appendix D, Part 20 of this chapter.

[47 FR 30456, July 14,1982, as amended at $52 \mathrm{FR}$ 31612, Aug. 21, 1987]

860.10 Completeness and accuracy of information.

(a) Information provided to the Commission by an applicant for a license or by a licensee or information required by statute or by the Commission's regulations, orders, or iscense conditions to be maintained by the applicant or the licensee shall be complete and accurate in all material respects.

(b) Each applicant or licensee shall notify the Commission of information identified by the applicant or licensee as having for the regulated activity a significant implication for public health and safety or common defense and security. An applicant or licensee violates this paragraph only if the applicant or licensee fails to notify the Commission of information that the applicant or licens'e has identified as having a significant implication for public health and safety or common defense and security. Notification shall be provided to the Administrator of the appropriate Regional Office within two working days of identifying the information. This requirement is not applicable to information which is already required to be provided to the Commission by other reporting or updating requirements.

[52 FR 49372, Dec. 31, 1987]

\section{Subpart B-Licenses}

\section{Preapplication Review}

\section{$8 \quad$ J.15 Site characterization.}

(a) Prior to submittal or an application for a license to be issued under this part DOE shall conduct a program of site characterization with respect to the site to be described in such application.

(b) Unless the Commission determines with respect to the site described in the application that it is not necessary, site characterization shall include a program of in situ exploration and testing at the depths that wastes would be emplaced.

(c) The prograin of site charac' srization shall be conducted in accordance with the following:

(1) Investigations to obtain the required information shall be conducted in such a marner as to limit adverse effects on the long-term performance of the geologic repository to the extent practical. 
(2) The number of exploratory boreholes and shafts shall be limited to the extent practical consistent with obtaining the information needed for site characterization.

(3) To the extent practical, exploratory boreholes and shafts in the geologic repository operations area shall be located where shafts are planned for underground facility construction and cperation or where large unexcavated pillars are planned.

(4) Subsurface exploratory drilling, excavation, and in situ testing before and during construction shall be planned and coordinated with geologic repository operations area design and construction.

[46 FR 13980, Feb. 25, 1981, as amended at 48 F'R 28219, June 21, 1983. RedesiEnated and arnended at 51 FR 271.62. July 30, 1986: 54 FR 278'71, July 3, 1989]

\$60.16 Site charthequriation plan required.

Before proceeding to sink shafts at any area which has been approved by the President for site characterization. DOE shall submit to the Director, for review and comment, a site characterization plan for such area. DOE shall defer the sinking of such shafts until such time as chere has been an opportunity for Commission comments thereon to have been solicited and considered by DOE.

[51 FR 27162, July 30, 1986]

$\$ 60.17$ Contents of site characterization plan.

The site characterization plan shall contair --.

(a) A general plan for site characteriz tion activities to be conducted at the area to be characterized, which general plan shall include:

(1) A description of such area, including information on quality assurance programs that have been applied to the collection, recording, and retention of information used in preparing such description.

(2) A description of such site characLerizatiun activities, inchidiare the for lowing -

(i) 'The extent of planned excava" tions: (ii) Plans for any onsite testing with radioactive material, including radioactive tracers, or nonradioactive material;

(iii) Plans for any investigation activities that may affect the capability of such area to isolate high-level radioactive waste;

(iv) Plans to control any adverse impacts from such site characterization activities that are important to safety or that are important to waste isolation; and

(v) Plans to apply quality assurance to data collection, recording, and retention.

(3) Plans for the decontamination and decommissioning of such area, ard for the mitigation of any significant adverse environmental impacts caused by site characterization activities, if such area is determined unsuitable for application for a construction authorization for a geologic repository operations area;

(4) Criteria, developed pursuant to section 112(a) of the Nuclear Waste Policy Act of 1982, to be used to determine the suitability of such area for the location of a geologic repository; and

(5) Ariy other information which the Commission, by rule or order, requires.

(b) A description of the possible waste form or waste package for the high-level radioactive waste to be $\mathrm{em}$ placed in such geologic repository, a description (to the extent practicable) of the relationship between such waste form or waste package and the host rock at such area, and a description of the activities being conducted by DOE with respect to such possible waste form or waste package or their relationship; and

(c) A conceptual design for the geologic repository operations area that takes into account likely site-specific requirements.

[51 FirR 27163, July 30, 1986] 
860.18 Review of site characterization activities. ${ }^{2}$

(a) The Director shall cause to be published in the FEDERA. Regrster a notice that a site characterization plan has been received frorn DOE and that a staff review of such plan has begun. The notice shall identify the area to be characterized and the NVC staff members to be consulted for further information.

(b) The Director shall make a copy of the site characterization plan available at the Public Document Room. The Director shall also transmit copies of the published notice of receipt to the Governor and legislature of the State in which the area to be characterized is located and to the governing body of any affected Lndian Tribe. The Director shall provide an opportu. nity, with respect to axy area to be characterized, for the state in which such area is located and for affected Indian Tribes to present their views on the site characterization plan and their suggestions with respect to comments thereon which daay be made by NRC. In acidition, the Dixector shail make NRC stafi avallable to consult with States and affected Indian Tribes as provided in Subpart $C$ of this part.

(c) The Director shall review the site characterization plas and prepare a site characterization analysis with respect to such plan. In the preparation of such site characterization analysis, the Director may invite and consider the views of interested persons on DOE's site characterization plan and may review and consider cornments made in connection with public hearings held by DOH.

(d) The Director sall provide to

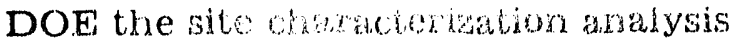

${ }^{2}$ In addition to the review of site charac. terization activities specified in this section, the Commission contemplates an ongoing review of other information on sile investi. gation and site characterization, in order to allow early identification of potential licens. ing issues for timely resolution. 'This activi. ty will include, for example, a review of the environmental assessments prepared by DOE at the time of site nornination, and review of issues lelated to long iead time ex. ploratory shafi planning and procurement actions by Doki prior to issuance of site characteritation plaxis. together with such additional comments as may be warranted. These comments shall include either a statement that the Director has no objection to the DOE's site characterization program, if such a statement is appropriate, or specific objections with respect to DOE's program for characterization of the area concerned. In addition, the Director may make specific recommendations pertinent to DOE's site characterization program.

(e) If DOE's plarned site characterization activities include onsite testing with radioactive material, including radioactive tracers, the Director's comments shall include a determination regarding whether or not the Commission concurs that the proposed use of such radioactive material is necessary to provide data for the preparation of the environmental reports required by law and for an application to be submitted under $\$ 60.22$ of this part.

(f) The Director shall publish in the Federal Register a notice of avallabil. ity of the site characterization anaylsis and a request for public comment. A reasonable period, not less than 90 days, shall be allowed for comment. Copies of the site characterization analysis and of the comments received shall be made available at the Public Document Room.

(g) During the conduct of site characterization activities, DOE shall report not less than once every six months to the Commission on the nature and extent of such activities and the information that has been developed, and on the progress of waste form and waste package research and development. The semiannual reports shall include the results of site characterization studies, the identification of new issues, plans for additional studies to resolve new issues, elimination of planred studies no longer necessary, identafication of decision points reached and modifications to schedule's where appropriate. DOE shall also report its progress in developing the design of a geologic repository operations area appropriate for the area being characterized, noting when key design naraineters or features which depend upon the results of site characterization will be established. Other topics related to site characterization 
shall also be covered if requested by the Director.

(h) During the conduct of site characterization activities, NRC staff shall be permitted to visit and inspect the locations at which such activities are carried out and to observe excavations, borings, and in situ tests as they are done.

(i) The Director may comment at any time in writing to DOE, expressing current views on any aspect of site characterization. In particular, such comments shall be made whenever the Director, upon review of comments invited on tire site characterization analysis or upon review of DOE's semiannual reports, determines that there are substantial new grounds for making recommendations or stating objections to DOE's site characterization program. The Director shall invite public comment on any comments which the Director makes to DOE upon review of the DOE semiannual reports or on any other comments which the Director makes to DOE on site characterization.

(j) The Director shall transmit copies of the site characterization analysis and all comments to DOE made by the Director under this section to the Governor and legislature of the State in which the area to be characterized is located and to the governing body of any affected Indian Tribe. When transmitting the site character. ization analysis under this paragraph, the Director shall invite the addressees to review and comment thereon.

(k) All correspondence between DOE and the NRC under this section, including the reports described in paragraph ( $\mathrm{g})$, shall be placed in the Public Document Room.

(1) The activities described in paragraphs (a) through ( $k$ ) of this section constitute informal conference between a prospective applicant and the staff, as described in $\S 2.101(a)(1)$ of this chapter, and are not part of a proceeding under the Atomic Energy Act of 1954, as amended. Accordingly, neither the issuance of a site characterization analysis nor any other comments of the Director made under this section constitutes a commitment to issue any authorization or iicense or in any way affect the authority of the
Commission, the Atomic Safety and Licensing Appeal Board, A.tomic Safety and Licensing Boards, other presiding officers, or the Director, in any such proceeding.

[51 FR 27163, July 30, 1986]

\section{LICENSE APPLICATIONS}

\section{$\$ 60.21$ Content of application.}

(a) An application shall consist of general information and a Safety Analysis Report. An environmental impact statement shall be prepared in accordance with the Nuclear Waste Policy Act of 1982, as amended, and shall accompany the application. Any Restric ed Data or National Security Information shall be separated from unclasisified information.

(b) The general information shall include:

(1) A general description of the proposed geologic repository identifying the location of the geologic repository operations area, the general character of the proposed activities, and the basis for the exercise of licensing authority by the Commission.

(2) Proposed schedules for construction, receipt of waste, and emplacement of wastes at the proposed geologic repository operations area.

(3) A certification that DOE will provide at the geologic repository operations area such safeguards as it requires at comparable surface facilities (of DOE) to promote the common defense and security.

(4) A description of the physical security plan for protection against radiological sabotage. Since the radiation hazards associated with high-level wastes make them inherently unattractive as a target for theft or diversion, no detailed information need be submitted on protection against theft or diversion.

(5) A description of site characteriza,tion work actually conducted by DOE at all sites considered in the application and, as appropriate, explanations of why such work differed from the description of the site chiracterization program described in the Site Characterization Report for each site.

(c) The Safety Añalydì Roport sha!! include: 
(1) A descripition and assessment of the site at which the proposed geolog. ic repository operations area is to be located with appropriate attuntion to those features of the sist might affect geologic reposich operations area design and performance. The description of the site shall identify the location of the geologic repository operations area with respect to the boundary of the accessible environment.

(i) The description of the site shall also include the following information regarding subsurface conditions. This description shall, in all cases, include such information with respect to the controlled area. In addition, where subsurface conditions outside the controlled area may affect isolation within the controlled area, the description shall include such info:mation with respect to subsurface conditions outside the controlled area to the extent such information is relevant and material. The detailed infor. mation referred to in this paragraph shall include:

(A) 'The orientation, distribution, aperture in-filling and origin of fractures, discontinuities, and heterogeneities;

(B) The presence and characteristics of other potential pathways such as solution features, breccia pipes, or other potentially permeable features;

(C) The geomechanical properties and conditions, including pore pressure and ambient stress conditions;

(D) The hydrogeologic properties and conditions;

(E) The geochemical properties; and

(F) The anticipated response of the geomechanical, hydrogeologic, and geochemical systems to the maximum design thermal loading, given the pattern of fractures and other discontinuities and the heat transfer properties of the rock mass and groundwater.

(ii) The assessment shall contain:

(A) An analysis of the geology, geophysics, hydrogeology, geochemistry, climatology, and meteorology of the site,

(B) Analyses to determine the degree to which each of the favorable and potentiaìiy adverse conduitioñs, if present, has been characterized, and the extent to which it contributes to or detracts from isolation. For the purpose of determining the presence of the potentially adverse conditions, investigations shall extend from the surface to a depth sufficient to determine critical pathways for radionuclide $\mathrm{ml}$. gration from the underground facility to the accessible environment. Potentially adverse conditions shall be investigated outside of the controlled area if they affect isolation within tide controlled area.

(C) An evaluation of the performance of the proposed geologic repository for the period after permanent closure, assuming anticipated processes and events, giving the rates and quantities of releases of radionuclides to the accessible environment as a function of time; and a similar evaluation which assumes the occurrence of unanticipated processes and events.

(D) The effectiveness of engineered and natural barriers, including barriers that may not be themselves a part of the geologic repository operations area, against the release of radioactive material to the environment. The analysis shall also include a comparative evaluation of alternatives to the major design features that are irnportant to waste isolation, with particular attention to the alternatives that would provide longer radionuclide containment and isolation.

(E) An analysis of the performance of the major design structures, systems, and components, both surface and subsurface, to identify those that are important to safety. For the purposes of this analysis, it shall be assumed that operations at the geologic repository operations area will be car. ried out at the maxirnurn capacity and rate of receipt of radio ctive waste stated in the application.

(F) An explanation of measures used to support the models used to perform the assessments required in paragraphs (A) through (D). Analyses and models that will be used to predict future conditions and changes in the geologic setting shall be supported by using an appropriate combination of such methods as field tests, in situ tests, laboratory iests which are representative of field conditions, monitoring data, and natural analog studies. 
(2) A description and discussion of the design, both surface and subsurface, of the geologic repository operations area including: (i) the principal design criteria and their relationship to any general performance objectives promulgated by the Commission, (ii) the design bases and the relation of the design bases to the principal design criteria, (iii) information relative to materials of construction (including geologic media, general arrangement, and approximate dimensions), and (iv) codes and standards that DOE proposes to apply to the design and construction of the geolog. ic repository operations area.

(3) A description and analysis of the design and performance requirements for structures, systems, and compo. nents of the geologic repository which are important to safety. This analysis shall consider-(i) The margins of safety under normal conditions and under conditions that may result from anticipated operational occurrences, including those of natural origin; and (ii) the adequacy of structures, systems, and components provided for the prevention of accidents and mitigation of the consequences of accidents, including those caused by natu. ral phenomena.

(4) A description of the quality assurance program to be applied to the structures, systems, and components important to safety and to the engineered and natural barriers important to waste isolation.

(5) A description of the kind, amount, and specifications of the radioactive material proposed to be received and possessed at the geologic repository operations area.

(6) An identification and justifica. tion for the selection of those variables, conditions, or other items which are determined to be probable subjects of license specifications. Special attention shall be given to those items that may significantly influence the final desien.

(7) A description of the program for control and monitoring of radioactive effluents and occupational radiation exposures to maintain such effluents and exposures in accordance with the requirements of Part 20 of this chapter.
(8) A description of the controls that the applicant will apply to restrict access and to regulate land use at the site and adjacent areas, including a conceptual design of monuments which would be used to identify the controlled area after permanent clo. sure.

(9) Plans for coping with radiological emergencies at any time prior to per. manent closure and decontamination or dismantlement of surface facilities.

(10) A description of the nuclear material control and accounting program.

(11) A description of design considerations that are intended to facilitate permanent closure and decontamination or dismantlement of surface facilities.

(12) A description of plans for retrieval and alternate storage of the ra. dioactive wastes should the geologic repository prove to be unsuitable for disposal of radioactive wastes.

(13) An identification and evaluation of the natural resources of the geolog. ic setting, including estimates as to undiscovered deposits, the exploitation of which could affect the ability of the geologic repository to isolate radioactive wastes. Undiscovered deposits of resources characteristic of the area shall be estimated by reasonable inference based on geological and geophysical evidence. This evaluation of resources, including undiscoverd deposits, shall be conducted for the site and for ireas of similar size that are representative of and are within the geolog. ic setting. For natural resources with current markets the resources shall be assessed, with estimates provided of both gross and net value. The estimate of net value shall take into account current development, extraction and marketing costs. For natural resources without current markets, but which would be marketable given credible projected changes in economic or technological factors, the resources shall be described by physical factors such as tonnage or other amount, grade, and quality.

(14) An identification of those structures, systems, and components of the geologic repository, both surface and subsurface, which require research and development to confirm the aciequacy of design. For structures, sys- 
tems, and components important to safety and for the engineered and natural barriers important to waste isola. tion, DOE shall provide a detailed de. scription of the programs designed to resolve safety questions, including a schedule indicating when these questions would be resolved.

(15) The following information con. cerning activities at the geologic repository operations area:

(i) The organizational structure of DOE as it pertains to construction and operation of the geologic repository operations area including a description of any delegations of authority and assignments of responsibilities, whether in the form of regulations, administra. tive directives, contract provisions, or otherwise.

(ii) Identification of key positions which are assigned responsibility for safety at and operation of the geologic repository operations area.

(iii) Persunnel qualifications and training requirements.

(iv) Plans for startup activities and startup testing.

(v) Plans for conduct of normal activities, including maintenance, sur. velllance, and periodic testing of structures, systems, and components of the geologic repository operation area.

(vi) Plans for permanent closure and plans for the decontamination or dismantlement of surface facilitie:

(vii) Plans for any uses of the geologic repository operations area for purposes other than disposal of radioactive wastes, with an analysis of the effe s, if any, that such uses may have upon the operation of the structures, systems, and components important to safety and the engineered and natural barriers important to waste isolation.

[46 FR. 13980, Feb. 25, 1981, as amended at 48 FR 28219, June 21, 1983; 54 FR 27871, July 3,1989 ]

$\$ 60.22$ Filing and distribution of application.

(a) An application for a license to receive and possess source, special nuclear, or byproduct material at a geologic repository operations area at a site which has been characterized, and any amendments thereto, and an accompanying environmental impact statement and any supplements, shall be signed by the Secretary of Energy or the Secretary's authorized representative and shall be filed in triplicate with the Director.

(b) Each portion of such application and any amendments, and each environmental impact statement and any supplements, shall be accompanied by 30 additional copies. Another 120 coples shall be retained by DOE for distribution in accordance with written instructions from the Director or the Director's designee.

(c) DOE shall, upon notification of the appointment of an Atomic Safety and Licensing Board, update the application, eliminating all superseded information, and supplement the environmental impact statement if necessary, and serve the updated application and environmental impact statement (as it may have been supplemented) as directed by the Board. At that time DOE shall also serve one such copy of the application and environmental impact statement on the Atomic Safety and Licensing Appeal Panel. Any subsequent amendments to the application or supplements to the environmental impact statement shall be served in the same manner.

(d) At the time of filing of an application and any amendments thereto, one copy shall be made available in an appropriate location near the proposed geologic repository operations area (which shall be a public document room, if one has been established) for inspection by the public and updated as amendments to the ap. plication are made. The environmental impact statement and any supplements thereto shall be made available in the same mianner. An updated copy of the application, and the environmental impact statement and supplements, silall be produced at any public hearing held by the Commission on the application, for use by any party to the proceeding.

(e) The DOE shall certify that the updated copies of the application, and the environmental impact statement as it may have been supplemented, as referred to in paragraphs (c) and (d) of this section, contain the current contents of such documents submitted 
in accordance with the requirements of this part.

[54 FR 27871. July 3, 1989]

\$ 60.23 Elimination of repetition.

In its application, environmental report, or Site Characterization Report, the DOE may' incorporate by reference information contained in previous applications, statements, or reports filed with the Commission: Provided, That such references are clear and specific and that copies of the information so incorporated are available in the public document room located near the site of the proposed geologic repository.

\$60.24 Updating of application and environmental impact statement.

(a) The application shall be as complete as possible in the light of information that is reasonably avallable at the time of docketing.

(b) The DOE shall update its application in a timely manner so as to permit the Commission to review, prior to issuance of a license:

(1) Additional geologic, geophysical, geochemical, hydurologic, meteorologic and other data obtained during con. struction.

(2) Conformance of construction of structures, systems, and components with the design.

(3) Results of research programs carried out to confirm the adequacy of designs.

(4) Other information bearing on the Commission's issuance of a license that was not available at the time a construction authorization was issued.

(c) The DOE shall sup lement its environmental impact statement in a timely manner so as to take into account the environmental impacts of any substantial changes in its proposed actions or any significant new circumstances or information relevant to environmental concerns and bear. ing on the proposed action or its im. pacts.

[46 FR 13980, Feb. 25, 1981, as amended at 54 F'R 27872. July 3, 1989]

\section{CONSTRUCTION Authorization}

$\$ 60.31$ Construction kuthorization.

Upon review and consideration of an application and environmental impact statement subinitted under this part, the Commission may authorize con. struction if it determines:

(a) Safety. That there is reasonable assurance that the types and amounts of radloactive materials described in the application can be received, possessed, and disposed of in a geologic repository operations area of the design proposed without unreasonable risk to the health and safety of the public. In arriving at this determination, the Commission shall consider whether:

(1) DOE has described the proposed geologic repository including but not limited to: (1) The geologic, geophysical, geochemical and hydrologic char. acteristics of the site; (ii) the kinds and quaritities of radioactive waste to be received, possessed, stored, and disposed of in the geologic repository operations area; (iii) the principal architectural and engineering criteria for the design of the geologic repository operations area; (jv) construction procedures which may affect the capability of the geologic repository tc serve its intended function; and ( $v$ ) features or components incorporated in the design for the protection of the health and safety of the public.

(2) The site and design comply with the performance objectives and criteria contained in Subpart $E$ of this part.

(3) The DOE's quality assurance program complies with the requirements of subpart $G$ of this part.

(4) The DOE's personnel training program complies with the criteria contained in Subpart $\mathrm{H}$ of this part.

(5) The DOE's emergency plan complies with the criteria contained in Subpart $Y$ of this part.

(6) 'The DOE's proposed operating procedures to protect health and to minimize danger to life or property are adequate.

(b) Common defense ond security. That there is reasonable assurance that the activities rroposed in the application will not be inumicai to the 
common defense and security. A DOIS certification that it will provide at the geologic repository operations area such safeguards as it requires at comparable DOE surface facilities to promote the common defense and securi. ty will constitute a rebuttable presumption of noninimicality to the common defense and security.

(c) Environmental. That, after weighing the environmental, econom ic, technical and other benefits against environmental costs and considering available alternatives, the action called for is issuance of the construc. tion authorization, with any appropri. ate conditions to protect environmental values.

[46 FR 13980, Feb, 25, 1981, as amended ul 48 F'R 28220, June 21, 1983; 54 F'R 2'78'72. July 3,1989 ]

$\$ 60.32$ Conditions of construction author' ization.

(a) A construction authorization shall include such corditions as the Commission finds to be necessary to protect the health and safety of the public, the common defense and secu. rity, or environmental values.

(b) The Commission will incorporate in the construction authorization pro. visions requiring DOE to furnish peri. odic or special reports regarding: (1) Progress of construction, (2) any datia about the site obtained during con. struction which are not within the predicted limits upon which the facility design was based, (3) any deficiencies in design and construction which, if uncorrected, could adversely affect safety at any future time, and (4) re sults of research and development pro. grams being conducted to resolve safety questions.

(c) The construction authorization will include restrictions on subsequent changes to the features of the geologic repository and the procedures authorized. The restrictions that may be imposed under this paragraph can include measures to prevent adverse effects on the geologic setting as well as measures related to the design and construction of the geologic repository operations area. These restrictions will fall into three categories of descending importance to public health and safety as follows: (1) Those features and pro- cedures which mas not be changed without: (i) 60 days prior notice to the Commatssion (ii) 30 days notice of opportunity for a prior hearing, and (iii) prior Commission approval; (2) those features and procedures which may not be changed without (i) 60 days prior notice to the Commission, and (ii) prior Commission approval; and (3) those features and procedures which may not be changed without 60 days notice to the Commission. Features and procedures falling in paragraph (c)(3) of this section may not be chariged without prior commission approval if the Commission, after having recelved the required notice, so orders.

(d) A construction authorization shall be subject to the limitation that a license to recelve and possess source, special nuclear, or byproduct material at the geologic repository operations area shall not be issued by the Commission until (1) the DOE has updated its application as specifled in $\$ 60.24$, and (2) the Commission has made the flndings stated in $\$ 60.41$.

146 FR 13980, Feb. 25, 1981, ass antended a. 48 Fin 28221, June 21, 1983]

$\$ 60.33$ Amendment of comstruction authorization.

(a) An application for amendment of a construction authorization shall be filed with the Commission fully describing any changes desired and following as far as applicable the format prescribed in $\$ 60.21$.

(b) In determining whether an amendment of a construction authorization will be approved, the Commission will be guided by the considerations which govern the issuance of the initial construction authorization, to the extent applicable.

\section{IIICENSE ISSUANCE AND ARENDMEN'I}

\$ 60.41 Standards for issuance of a license.

A license to receive and possess source, special nuclear, or byproduct material at a geologic repository operations area may be issued by the Commission upon findirig that:

(a) Construction of the geologic repository operations area has been sub. stantially completed in conformity 
with the application as amended, the provisions of the Atomic Energy Act, and the rules and regulations of the Commission. Construction may be deemed to be substantially complete for the purposes of this paragraph if the construction of (1) surface and interconnecting structures, systems, and components, and (2) any underground storage space required for inl. tial operation are substantlally com. plete.

(b) The activities to be conducted at the geologic repository operations area will be in conformity with the application as amended, the provisions of the Atomic Energy Act and the Energy Reorganization Act, and the rules and regulations of the Commission.

(c) The issuance of the license will not be inimical to the common defense and security and will not constitute an unreasonable risk to the health and safety of the public. A DOE certification that it will provide at the geologic repository operations area such safeguards as it requires at comparable DOE facilities to promote the common defense and security, will constitute a rebuttable precumption of non-inimicality to the winmon defense and security.

(d) All applicable requirements of Part 51 have been satisfied.

\section{$\$ 60.42$ Conditions of license.}

(a) A license issued pursuant to this part shall include such conditions, including license specifications, as the Commission finds to be necessary to protect the health and safety of the public, the common defense and security, and environmental values.

(b) Whether stated therein or not, the following shall be deemed conditions in every licerise issued:

(1) The license shall be subject to revocation, suspension, modification, or amendment for cause as provided by the Atomic Energy Act and the Commission's regulations.

(2) The DOE shall at any time while the license is in effect, upon written request of the Commission, submit written statements to enable the Com. mission to determine whether or not the license should be modified, sus. pended or revoked.
(3) The license shall be subject to the provisions of the Atomic Energy Act now or hereafter in effect and to all rules, regulations, and orders of the Commission. The terms and conditions of the license shall be subject to amendment, revision, or modification, by realion of amendments to or by reason of rules, regulations, and orders issued in accordance with the terms of the Atomic Energy Act.

(c) Each license shall be deemed to contain the provisions set forth in Section $183 \mathrm{~b}-\mathrm{d}$, inclusive, of the Atomic Energy Act, whether or not these pro. vislons are expressly set forth in the li. cense.

\subsection{License specification.}

(a) A license issued under this part shall include license conditions derived from the analyses and evaluations in. cluded in the application, including amendments made before a license is issued, together with such additional conditions as the Commission finds ap. propriate.

(b) License conditions shall include items in the following categories:

(1) Restrictions as to the physical and chemical form and radiolsotoplc content of radioactive waste.

(2) Restrictions as to size, shape, and materials and methods of construction of radioactive waste packaging.

(3) Restrictions as to the arnount of waste permisted per unit volume of storage space considering the physical characteristics of both the waste and the host rock.

(4) Requirements relating to test, calibration, or inspection to assure that, the foregoing restrictions are ob. served.

(5) Controls to be applied to restrict. ed accuss and to avold disturbance to the controlled area and to areas outside the controlled area where conditions may affect isolation within the controlled area.

(6) Administrative controls, which are the provisions relating to organization and management, procedures, recordkeeping, review and audit, and reporting necessary to assure that activities at the facllity are conducted in a safe manner and in conformity with the other license specifications. 
[46 FR 13980, Feb, 25, 1981, as amended at 48 FR 28221, June 21, 1983]

8 60.44 Changes, tests, and experiments.

(a)(1) Following authorization to re. ceive and possess source, special nucle. ar, or byproduct material at a geologic repository operations area, the DOE may (i) make changes in the geologic repository operations area as described in the application, (1i) make changes in the procedures as described in the application, and (iii) conduct tests or experiments not described in the application, without prior Commission approval, provided the change, test, or experiment involves nelther a change in the license conditions incorporated in the license nor an unreviewed safety question.

(2) A proposed change, test, or experiment shall be deemed to involve an unreviewed safety question if (i) the likellhood of occurrence or the consequences of an accident or mal. function of equipment important to safety previously evaluated in the ap. plication is increased, (ii) the possibility of an accident or malfunction of a different type than any previnusly evaluated in the application is created, or (iii) the margin of safety as defined in the basis for any license condition is reduced.

(b) The DOE shall maintain records of changes in the geologic repository operations area and of changes in procedures made pursuant to this section, to the extent that such changes constitute changes in the geologic reposi. tory operations area or procedures as described in the application. Records of tests and experiments carried out pursuant to paragraph (a) of this section shall also be maintained. These records shali include a written safety evaluation which provides the basis for the determination that the change, test, or experiment does not involve an unreviewed safety question. The DOE shall prepare annually, or at such shorter iniervals as may be specified in the license, a report containing a brief description of such changes, tests, and experiments, including a summary of the safety evaluation of each. The DOE shall furnish the report to the appropriate NRC Regional Office shown in Appendix $D$ of
Part 20 of this chapter with a copy to the Director, Office of Nuclear Materi. al Safety and Safeguards, U.S. Nuclear Regulatory Commission, Washington, D.C. 20555. Any report submitted pur. suant to this paragraph shall be made a part of the public record of the 11 . censing proceedings.

[46 FR 13980, Feb. 25, 1981, as amended at 52 FR 31812, Aug. 21, 1987]

\section{\$60.45 Amendment of license.}

(a) An application for amendment of a license may be filed with the Commission fully describing the changes desired and following as far as applica. ble the format prescribed for license applications.

(b) In determining whether an amendment of a license will be approved, the Commission will be guided by the considerations that govern the issuance of the initial license, to the extent applicable.

\subsection{Particular activities requiring li-} cense amendment.

(a) Unless expressly authorized in the license, an amendment of the 11 cense shall be required with respect to any of the following activities:

(1) Any action wrilch would make emplaced high-level radioactive waste irretrievable or which would substantially increase the difficulty of retriev. ing such emplaced waste.

(2) Dismantling of structures.

(3) Removal or reduction of controls applied to restrict access to or avold disturbance of the controlled area and to areas outside the controlled area where conditions may affect isolation within the controlled area.

(4) Destruction or disposal of records required to be maintained under the provisions of this part.

(5) Any substantial cliange to the design or operating procedures from that specified in the license.

(6) Permanent closure.

(7) Any other activity involving an unreviewed safety question.

(b) An application for such an amendment shall be flled, and shall be r.viewed, in accordance with the provisions of $\$ 60.45$.

[46 FR 13980, F'eb. 25, 1981, as amended at 48 FR 28221, June 21, 1983] 


\section{Pgrmanent Crosure}

8 60.51 License amendment for permanent closure.

(a) DOE shall submit an application to amend the llcense prior to perma. nent closure. The submission shall consist of an undate of the llcense ap. plication silbmicted under \&\& 60.21 and 60.22, including:

(1) A description of the program for post-permanent closure monltoring of the geologic repository.

(2) A detalled description of the measures to be ernployed-such as land use controls, construction of monuments, and preservation of records-to regulate or prevent activl. ties that could impair the long-term isolation of emplaced waste within the geologic repostiory and to assure that relevant information will be preserved for the use of future generations. As a minimum, such measures shall in. clude:

(i) Identification of the controlled area and geologic repository oper. ations area by monuments that have been designed, fabricated, and emplaced to be as permanent as is practi. cable; and

(ii) Placement of records in the archives and land record systems of local State, and Federal government agen cies, and archives elsewhere in the world, that would be likely to be consulted by potential human intruderssuch records to identify the location of the geologic repository operations area, including the underground facillty, boreholes and shafts, and the boundarles of the controlled area, and the nature and hazard of the waste.

(3) Geologic, geophysical, geochemical, hydrologic, and other site data that are obtained during the operational period pertinent to the longterm isolation of emplaced radioactive wastes.

(4) The results of tests, experiments, and any other analyses relating to backfill of excavated areas, shaft sealing, waste interaction with the host rock, and any other tests, experiments, or analyses pertinent to the long-term isolation of emplaced wastes within the geologic repository.

(5) Any substantial revision of plans for permanent closire.
(6) Other Information bearing upon permanent closure that was not avall. able at the time a license was issued.

(b) If necessary, so as to take into ac. count the environmental impact of any substantial changes in the perma. nent closure activitles proposed to be carried out or any significant new in. formation regarding the environmen. tal Impacts of such closure, DOE shall also supplement its environmental impact statement and submit such statement, as supplemented, with the appllcation for license amendment.

[46 FR 13980, Feb. 25, 1981, as amended at 48 FR 28221, June 21, 1983; 54 FR 27872, July 3, 1889]

\section{\$60.52 Termination of license.}

(a) Following permanent closure and the decontamination or dismantle. ment of surface facllities, DOE may apply for an amendment to terminate the license.

(b) Such application shall be filed, and will be reviewed, in accordance with the provisions of $\$ 60.45$ and this section.

(c) A license shall be terminated only when the Commission finds with respect to the geologic repository:

(1) That the final disposition of radioactive wastes has been made in conformance with the DOE's plan, as amended and approved as part of the license.

(2) That the final state of the geologic repository operations area conforms to DOE's plans for permanent closure and DOE's plans for the decontamination or dismantlement of surface facilities, as amended and approved as part of the llcense.

(3) That the termination of the 11 cense is authorlzed by law, including sections 57, 62, and 81 of the Atomic Energy Act, as amended.

[46 FR 13980, Feb. 25, 1981, as amended at 48 FR 28222, June 21, 1983]

\section{Subpart C-Participation by State Governments and Affected Indian Tribes}

SOURCE: 51 F'R 27164, July 30, 1986, unless otherwise noted. 


\subsection{Provision of information.}

(a) The Director shall provide to the Governor and leglslature of any State In which a geologlc repository operations area is or may be located, and to the governing body of any affected Indian Tribe, timely and complete in. formation regarding determinations or plans made by the Commission with respect to the site characterization, siting, development, design, llcensing, construction, operation, regulation, permanent closure, or decontamination and dismantlement of surface fa. cillties, of such geologic repository op. erations area.

(b) For purposes of this section, a geologic repository operations area shall be considered to be one which "may be located" In a State if the loca. tion thereof in such State has been described in a site characterization plan submitted to the Commission under this part.

(c) Notwlthstanding paragraph (a) of this section, the Director is not required to distribute any document to any entity if, with respect to such document, that entity or its counsel is included on a service list prepared pur. suant to Part 2 of this chapter.

(d) Coples of all communications by the Director under this section shall be placed in the Public Document Room, and copies thereof shall be fur. nished to DOE.

\section{ş60.62. Site review.}

(a) Whenever an area has been approved by the President for site char. acterization, and upon request of a State or an affected Indian Tribe, the Director shall make NRC staff avail. able to consult with representatives of such States and Tribes.

(b) Requests for consultation shall be made in writing to the Director.

(c) Consultation under this section may include:

(1) Keeping the parties informed of the Director's views on the progress of site characterization.

(2) Review of applicable NRC regulations, licensing procedures, schedules, and opportunities for State and Tribe participation in the Commission's reg. ulatory activities.
(3) Cooperation in development of proposals for State and Tribe partlcl. pation in license reviews.

\section{\$ 60.63 Participation in license reviews.}

(a) State and local goverruments and affected Indian Tribes may participate in llcense revlews as provided in Sub. part $G$ of Part 2 of this chapter. A State in whlch a repository for high. level radloactive waste is proposed to be located and any affected Indlan Tribe shall have an unquestionable legal right to participate as a party in such proceedings.

(b) In addition, whenever an area has been approved by the President for site characterization, a State or an affected Indian Tribe may submit to the Director a proposal to facllitate its particlpation in the review of a site characterization plan and/or license application. The proposal may be sub. mitted at any time and shall contain a description and schedule of how the State or affected Indian Tribe wishes to participate in the review, or what services or activities the State or affected Indian Tribe wishes NRC to carry out, and how the services or activities proposed to be carried out by NRC would contribute to such particlpation. The proposal may include educational or information services (seminars, public meetings) or other actions on the part of NRC, such as establishing additional public document rooms or employment or exchange of State personnel under the Intergovernmental Personnel Act.

(c) The Director shall arrange for a meeting between the representatives of the State or affected Indian Tribe and the NRC staff to discuss any proposal submitted under paragraph (b) of this section, with a view to identify. ing any modifications that may contrlbute to the effective participation by such State or 'Tribe.

(d) Subject to the avallability of funds, the Director shall approve all or any part of a proposal, as it may be modified through the mesting described above. if it is determined that:

(1) The proposed activities are suitable in light of the type and magnitude of impacts which the State or affected Indian Tribe may bear; 
(2) The proposed activities:

(i) Will enhance communications between NRC and the State or affected Indian Tribe;

(ii) Will make a productive and timely contribution to the review; and

(iii) Are authorized by law.

(e) The Director will advise the State or affected Indian Tribe whether its proposal has been accepted or denied, and if all or any part of pro. posal is denied, the Director shall state the reason for the denial.

(f) Proposals submitted under this section, and responses thereto, shall be made available at the Public Document Room.

\subsection{Notice to States.}

If the Governor and legislature of a State have jointly designated on their behalf a single person or entity to receive notice and information from the Commission under this part, the Commission will provide such notice and information to the jointly designated person or entity instead of the Governor and legislature separately.

\section{\$60.65 Representation.}

Any person who acts under this subpart as a representative for a State (or for the Governor or legislature thereof) or for an affected Indian Tribe shall include in the request or other submission, or at the request of the Commission, a statement of the basis of his or her authority to act in such representative capacity.

\section{Subpart D-Records, Reports, Tesfs, and Inspections}

Source: 48 FR 28222, June 21, 1983, unless otherwise noted.

\section{\$ 60.71 Records and reports.}

(a) DOE shall maintain such records and make such reports in connection with the licensed activity as may be required by the conditions of the license or by rules, regulations, and orders of the Commission as authorized by the Atomic Energy Act and the Energy Reorganization Act.

(b) Records of the receipt, handling, and disposition of radioactive waste at a geologic repository operations area shall contain sufficient information to provide a complete history of the movement of the waste from the shipper through all phases of storage and disposal. DOE shall retain these records in a manner that ensures their useability for future generations in accordance with $\S 60.51(\mathrm{a})(2)$.

[48 FR 28222 June 21, 1983, as amended at 53 FR 19251, May 27, 1988]

\subsection{Construction records.}

(a) DOE shall maintain records of construction of the geologic repository operations area in a manner that ensures their useability for future generations in accordance with $\$ 60.51(\mathrm{a})(2)$.

(b) 'The records required under paragraph (a) shall include at least the following:

(1) Surveys of the underground facility excavations, shafts, and boreholes referenced to readily identifiable surface features or monuments;

(2) A description of the materials encountered;

(3) Geologic maps and geologic cross sections;

(4) Locations and amount of seepage;

(5) Details of equipment, methods, progress, and sequence of work;

(6) Construction problems;

(7) Anomalous conditions encountered;

(8) Instrument locations, readings, and analysis;

(9) Location and description of structural support systems;

(10) Location and description of dewatering systems; and

(11) Details, methods of emplacement, and location of seals used.

[ 48 F'R 28222 June 21,1983 , as amended at 53 FR 19251, May 27, 1988]

\section{\$60.73 Reports of deficiencies.}

DOE shall promptly notify the Com. mission of each deficiency found in the characteristics of the site, and design and construction of the geolog. ic repository operations area which, were it to remain uncorrected, could: (a) Be a substantial safety hazard, (b) represent a significant deviation from the design criteria and design bases stated in the application, or (c) represent a deviation from the conditions 
stated in the terms of a construction authorization or the license, including license specifications. The notification shall be in the form of a written report, copies of which shall be sent to the Director and to the appropriate Nuclear Regulatory Commission Regional Office listed in Appendix $D$ of Part 20 of this chapter.

\section{$\$ 60.74$ Tests.}

(a) DOE shall perform, or permit the Commission to perform, such tests as the Commission deems appropriate or necessary for the administration of the regulations in this part. These may include tests of:

(1) Radioactive waste,

(2) The geologic repository including its structures, systems, and components,

(3) Radiation detection and monitoring instruments, and

(4) Other equipment and devices used in connection with the receipt, handling, or storage of radioactive waste.

(b) The tests required under this section shall include a performance confirmation program carried out in accordance with Subpart F of this part.

$\$ 60.75$ Inspections.

(a) DOE shall allow the Commission to inspect the premises of the geologic repository operations area and adjacent areas to which DOE has rights of access.

(b) DOE shall make available to the Commission for inspection, upon reasonable notice, records kept by DOE pertaining to activities under this part.

(c)(1) DOE shall upon requests by the Director, Office of Nuclear Material Safety and Safeguards, provide rent-free office space for the exclusive use of the Commission inspection personnel. Heat, air-conditioning, light, electrical outlets and janitorial serv. ices shall be furnished by DOE. The office shall be convenient to and have full access to the facility and shall provide the inspector both visual and acoustic privacy.

(2) The space provided shall be ade quate to accommodate a full-time inspector, a part-time secretary and transient NRC personnel and will be generally commensurate with other office facilities at the geologic repository operations area. A space of 250 square feet either within the geologic repository operations area's office complex or in an office trailer or other onsite space at the geologic repository operations area is suggested as a guide. For locations at which activities are carried out under licenses issued under other parts of this chapter, additional space may be requested to accomodate additional full-time inspectors. The Office space that is provided shall be subject to the approval of the Director, Office of Nuclear Material Safety and Safeguards. All furniture, supplies and communication equipment will be furnished by the Commission.

(3) DOE shall afford any NRC resident inspector assigned to that location, or other NRC inspectors identified by the Regional Administrator as likely to inspect the facility, immediate unfettered access, equivalent to access provided regular employees, following proper identification and compliance with applicable access control measures for security, radiological protection and personal safety.

[ 48 FR 28222. June 21, 1983, as amended at 52 FR 31612. Aug. 21, 1987]

\section{Subpart E-Technical Criteria}

SOURCE: 48 FR 28222, June 21, 1983, unless otherwise noted.

\section{\$ 60.101 Purpose and nature of findings.}

(a)(1) Subpart B of this part prescribes the standards for issuance of a license to receive and possess source, special nuclear, or byproduct material at a geologic repository operations area. In particular, $\$ 60.41$ (c) requires a finding that the issuance of a license will not constitute an unreasonable risk to the health and safety of the public. The purpose of this subpart is to set out performance objectives and site and design criteria which, if satisfied, will support such a finding of no unreasonable risk.

(2) While these performance objec. tives and criteria are generally stated in unqualified terms, it is not expected that complete assurance that they will be met can be presented. A reasonable assurance, on the hasis of the record 
before the Commission, that the objectives and criteria will be met is the general standard that is required. For $\$ 60.112$, and other portions of this subpart that impose objectives and criteria for repository performance over long times into the future, there will inevitably be greater uncertainties. Proof of the future performance of engineered barrier systems and the geologic setting over time periods of many hundreds or many thousands of years is not to be had in the ordinary sense of the word. For such long-term objectives and criteria, what is required is reasonable assurance, making allow. ance for the time period, hazards, and uncertainties involved, that the outcome will be in conformance with those objectives and criteria. Demonstration of compliance with such objectives and criteria will involve the use of data from accelerated tests and predictive models that are supported by such measures as field and laboratory tests, monitoring data and natural analog studies.

(b) Subpart B of this part also lists findings that must be made in support of an authorization to construct a geologic repository operations area. In particular, $\S 60.31$ (a) requires a finding that there is reasonable assurance that the types and amounts of radioactive materials described in the application can be received, possessed, and disposed of in a geologic repository operations area of the design proposed without unreasonable risk to the health and safety of the public. As stated in that paragraph, in arriving at this determination, the Commission will consider whether the site and design comply with the criteria contained in this subpart. Once again, while the criteria may be written in unqualified terms, the demonstration of compliance may take uncertainties and gaps in knowledge into account. provided that the Commission can make the specified finding of reasonable assurance as specified in paragraph (a) of this section.

\subsubsection{Concepts.}

This section provides a functional overview of Subpart E. In the event of any inconsistency with definitions found in $\$ 60.2$, those definitions shall prevail.

(a) The HLW facility. NRC exercises licensing and related regulatory authority over those facilities described in section 202 (3) and (4) of the Energy Reorganization Act of 1974. Any of these facilities is designated a HLW facility.

(b) The geologic repository operations area. (1) This part deals with the exercise of authority with respect to a particular class of HLW facilitynamely a geologic repository operations area.

(2) A geologic repository operations area consists of those surface and subsurface areas that are part of a geologic repository where radioactive waste handling activities are conducted. The underground structure, including openings and backfill materials, but excluding shafts, boreholes, and their seals, is designated the underground facility.

(3) The exercise of Commission authority requires that the geologic repository operations area be used for storage (which includes disposal) of high-level radioactive wastes ( $H L W$ ).

(4) HLW includes irradiated reactor fuel as well as reprocessing wastes. However, if DOE proposes to use the geologic repository operations area for storage of radioactive waste other than HLW, the storage of this radioactive waste is subject to the requirements of this part.

(c) Aress related to isolation. Although the activities subject to regulation ur:der this part are those to be carried out at the geologic repository operations area, the licensing process also corisiders characteristics of adjacent areas that are defined in other ways. There is to be an area surrounding the underground facility referred to above. which is designated the controlled area, within which DOE is to exercise snecified controls to prevent adverse human actions following permanent closure. The location of the controlled area is the site. The accessible environment is the atmosphere, land surface, surface water, oceans, and the portion of the lithosphere that is outside the controlled area. There is an area, designated the geologic setting, which includes the geo- 
logic, hydrologic, and geochemical sys. tems of the regiun in which a geologic repository operations area is or may be located. The geologic repository operations area plus the portion of the geologic setting that provides isolation of the radioactive waste make up the geologic repository.

(d) Stages in the licensing process. There are several stages in the licensing process. The site characterization stage, though begun before submission of a license application, may result in consequences requiring evaluation in the license review. The construction stage would follow, after issuance of a construction authorization. A period of operations follows the issuance of a license by the Commission. The period of operations includes the time during which emplacement of wastes occurs; any subsequent period before permanent closure during which the emplaced wastes are retrievable; and permanent closure, which includes sealing of shafts. Permanent closure represents the erd of active human intervention with respect to the engineered barrier system.

(e) Isolation of waste. (1) During the first several hundred years following permanent closure of a geologic repository, when radiation and thermal levels are high and the uncertainties in assessing repository performance are large, special emphasis is placed upon the ability to contain the wastes by waste packages within an engineered barrier system. This is known as the containment period. The engineered barrier system includes the waste packages and the underground facility. A waste package is composed of the waste form and any containers, shielding, packing, and absorbent materials immediately surrounding an individual waste container. The underground facility means the under. ground structure, including openings and backfill materials, but excluding, shafts, boreholes, and their seals.

(2) Following the containment period special emphasis is placed upon the ability to achieve isolation of the wastes by virtue of the characteristics of the geologic repository. The engineered barrier system works to control the release of radioactive material to the geologic setting and the geologic setting works to control the release of radioactive material to the accessible environment. Isolation means inhibiting the transport of radioactive materisis so that amounts and concentrations of the materials entering the accessible environment will be kept within prescribed limits.

\section{Performance Objectives}

\$60.111 Performance of the geologic repository operations area through permanent closure.

(a) Protection against radiation exposures and releases of radioactive material. The geologic repository operations area shall be designed so that until permanent closure has been completed, radiation exposures and radiation levels, and releases of radioactive materials to unrestricted areas, will at all times be maintained within the limits specified in Part 20 of this chapter and such generally applicable environmental standards for radioactivity as may have been established by the Environmental Protection Agency.

(b) Retrievability of waste. (1) The geologic repository operations area shall be designed to preserve the option of waste retrieval throughout the period during which wastes are being emplaced and, thereafter, until the completion of a preformance confirmation program and Commission review of the information obtained from such a program. To satisfy this objective, the geologic repository operations area shall be designed so that any or all of the emplaced waste could be retrieved on a reasonable schedule starting at any time up to 50 years after waste emplacement operations are initiated, unless a different time period is approved or specified by the Commission. This different time period may be established on a caseby-case basis consistent with the emplacement schedule and the planned performance confirmation program.

(2) This requirement shall not preclude decisions by the Commission to allow backfilling part or all of, or permanent closure of, the geologic repository operations area prior to the end of the period of design for retrievability. 
(3) For purposes of this paragraph, a reasonable schedule for retrieval is one that would permit retrieval in about the same time as that devoted to construction of the geologic repository operations area and the emplacement of wastes.

\$60.112 Overall system performance objective for the geologic repository after permanent closure.

The geologic setting shall be selected and the engineered barrier system and the shafts, boreholes and their seals shall be designed to assure that releases of radioactive materials to the accessible environment following permanent closure conform to such generally applicable environmental standardi for radioactivity as may have been established by the Environmental Protection Agency with respect to both anticipated processes and events and unanticipated processes and events.

\$60.113 Performance of particular barriers after permanent closure.

(a) General provisions-(1) Engineered barrier system. (i) The engineered barrier system shall be designed so that assuming anticipated processes and events: (A) Containment of HLW will be substantially complete during the period when radiation and thermal conditions in the engineered barrier system are dominated by fission product decay; and (B) any release of radionuclides from the engineered barrier system shall be a gradual process which results in small fractional releases to the geologic setting over long times. For disposal in the saturated zone, both the partial and complete filling with groundwater of available void spaces in the underground facility shall be appropriately considered and analysed among the anticipated processes and events in designing the engineered barrier system.

(ii) In satisfying the preceding requirement, the engineered barrier system shall be designed, assuming anticipated processes and events, so that:

(A) Containment of HLW within the waste packages will be substantially complete for a period to be determined by the Commission taking into account the factors specified in
$\$ 60.113$ (b) provided, that such period shall be not less than 300 years nor more than 1.000 years after permanent closure of the geologic repository; and

(B) The release rate of any radionuclide from the engineered barrier system following the containment period shall not exceed one part in 100,000 per year of the inventory of that radionuclide calculated to be present at 1,000 years following permanent closure, or such other fraction of the inventory as may be approved or specified by the Commission; provided, that this requirement does not apply to any radionuclide which is released at a rate less than $0.1 \%$ of the calculated total release rate limit. The calculated total release rate limit shall be taken to be one part in 100,000 per year of the inventory of radioactive waste, originally emplaced in the underground facility, that remains after 1,000 years of radioactive decay.

(2) Geologic setting. The geologic repository shall be located so that prewaste-emplacement groundwater travel time along the fastest path of likely radionuclide travel from the disturbed zone to the accessible environment shall be at least 1,000 years or such other travel time as may be approved or specified by the Commission.

(b) On a case-by-case basis, the Commission may approve or specify some other radionuclide release rate, designed containment period or prewaste-emplacement groundwater travel time, provided that the overall system performance objective, as it relates to anticipated processes and events, is satisfied. Among the factors that the Commission may take into account are:

(1) Any generally applicable environmental standard for radioactivity established by the Environmental Protection Agency;

(2) The age and nature of the waste, and the design of the underground facility, particularly as these factors bear upon the time during which the thermal pulse is dominated by the decay heat from the fission products;

(3) The geochemical characteristics of the host rock, surrounding strata and groundwater; and 
(4) Particular sources of uncertainty in predicting the performance of the geologic repository.

(c) Additional requirements may be found to be necessary to satisfy the overall system performance objective as it relates to unanticipated processes and events.

\section{LAND OWNERSHIP AND CONTROL}

8 60.121 Requirements for ownership and control of interests in land.

(a) Ownership of land. (1) Both the geologic repository operations area and the controlled area shall be located in and on lands that are either acquired lands under the jurisdiction and control of DOE, or lands perma. nently withdrawn and reserved for its use.

(2) These lands shall be held free and clear of all encumbrances, if sig. nificant, such as: (i) Rights arising under the general mining laws; (ii) easements for right-of-way; and (iii) all other rights arising under lease, rights of entry, deed, patent, mortgage, appropriation, prescription, or otherwise.

(b) Additional controls. Appropriate controls shall be established outside of the controlled area. DOE shall exer. cise any jurisdiction and control over surface and subsurface estates neces. sary to prevent adverse human actions that could significantly reduce the geologic repository's ability to achieve isolation. The rights of DOE may take the form of appropriate possessory interests, servitudes, or withdrawals from location or patent under the general mining laws.

(c) Water rights. (1) DOE shall also have obtained such water rights as may be needed to accomplish the purpose of the geologic repository operations area.

(2) Water rights are included in the additional controls to be established under paragraph (b) of this section.

\section{Siting Criteria}

\subsection{Siting criteria.}

(a)(1) A geologic setting shall exhibit an appropriate combination of the conditions specified in paragraph (b) of this section so that, together with the engineered barriers system, the favorable conditions present are sufficient to provide reasonable assurance that the performance objectives relating to isolation of the waste will be met.

(2) If any of the potentially diverse conditions specified in paragriph (c) of this section is present, it may compromise the ability of the geologic repository to meet the performance objectives relating to isolation of the waste. In order to show that a potentially adverse condition does not so compromise the performance of the geologic repository the following rnust be demonstrated:

(i) The potentially adverse human activity or natural condition has been adequately investigated, including the extent to which the condition may be present and still be undetected taking into account the degree of resolution achieved by the investigations; and

(ii) The effect of the potentially adverse human activity or natural condition on the site has been adequately evaluated using analyses which are sensitive to the potentially adverse human activity or natural condition and assumptions which are not likely to underestimate its effect; and

(iii)(A) The potentially adverse human activity or natural condition is shown by analysis pursuant to paragraph $(a)(2)(i i)$ of this section not to affect significantly the ability of the geologic repository to meet the performance objectives relating to isolation of the waste, or

(B) The effect of the potentially adverse human activity or natural condition is compensated by the presence of a combination of the favorable characteristics so that the performance objectives relating to isolation of the waste are met, or

(C) The potentially adverse human activity or natural condition can be remedied.

(b) Favorable conditions. (1) The nature and rates of tectonic, hydrogeologic, geochemical, and geomorphic processes (or any of such processes) operating within the geologic setting during the Quaternary Period, when projected, would not affect or would favorably affect the ability of the geologic repository to isclate the waste. 
(2) For disposal in the saturated zone, hydrogeologic conditions that provide:

(i) A host rock with low horizontal and vertical permeability:

(ii) Downward or dominantly horizontal hydraulic gradient in the host rock and immediately surrounding hydrogeologic units; and

(iii) Low vertical permeability and low hydraulic gradient between the host rock and the surrounding hydrogeologic units.

(3) Geochemical conditions that:

(i) Promote precipitation or sorption of radionuclides;

(ii) Inhibit the formation of particulates, colloids, and inorganic and organic complexes that increase the mobility of radionuclides; or

(iii) Inhibit the transport of radionuclides by particulates, colloids, and complexes.

(4) Mineral assemblages that, when subjected to anticipated thermal load. ing, will remain unaltered or alter to mineral assemblages having equal or increased capacity to inhibit radionuclide migration.

(5) Conditions that permit the emplacement of waste at a minimum depth of 300 meters from the ground surface. (The ground surface shall be deemed to be the elevation of the lowest point on the surface above the disturbed zone.)

(6) A low population density within the geologic setting and a controlled area that is remote from population centers.

(7) Pre-waste-emplacement groundwater travel time along the fastest path of likely radionuclide travel from the disturbed zone to the accessible environment that substantially exceeds 1,000 years.

(8) For disposal in the unsaturated zone, hydrogeologic conditions that provide-

(i) Low moisture flux in the host rock and in the overlying and underlying hydrogeologic units;

(ii) A water table sufficiently below the underground facility such that fully saturated voids contiguous with the water table do not encounter the underground facility;

(iii) A laterally extensive low-permeability hydrogeologic unit above the host rock that would inhibit the downward movement of water or divert downward moving water to a location beyond the limits of the underground facility;

(iv) A host rock that provides for free drainage; or

(v) A climatic regime in which the average annual historic precipitation is a small percentage of the average annual potential evapotranspiration.

(c) Potentially adverse conditions. The folluwing conditions are potentially adverse conditions if they are characteristic of the controlled area or may affect isolation within the controlled area.

(1) Potential for flooding of the underground facility, whether resulting from the occupancy and modification of floodplains or from the failure of existing or planned man-made surface water impoundments.

(2) Potential for foreseeable human activity to adversely affect the groundwater flow system, such as groundwater withdrawal, extensive irrigation, subsurface injection of fluids, underground pumped storage, military activity or construction of large scale surface water impoundments.

(3) Potential for natural phenomenu such as landslides, subsidence, or volcanic activity of such a magnitude that large-scale surface water impoundments could be created that could change the regional groundwater flow system and thereby adversely affect the performance of the geologic repository.

(4) Structural deformation, such as uplift, subsidence, folding, or faulting that may adversely affect the regional groundwater flow systern.

(5) Potential for changes in hydrologic conditions that would affect the migration of radionuclides to the accessible environment, such as changes in hydraulic gradient, average interstitial velocity, storage coefficient, hydraulic conductivity, natural recharge, potentiometric levels, and discharge points.

(6) Potential for changes in hydrologic conditions resulting from reasonably foreseeable climatic changes.

(7) Groundwater conditions in the host rock, including chemical composition, high ionic strength or ranges of 
Eh-pH, that could increase the solubility or chemical reactivity of the engineered barrier system.

(8) Geochemical processes that would reduce sorption of radionuclides, result in degradation of the rock strength, or adversely affect the performance of the engineered barrier system.

(9) Groundwater conditions in the host rock that are not reducing.

(10) Evidence of dissolutioning such as breccia pipes, dissolution cavities, or rrine pockets.

(11) Structural deformation such as uplift, subsidence, folding, and faulting during the Quaternary Period.

(12) Earthquakes which have occurred historically that if they were to be repeated could affect the site significantly.

(13) Indications, based on correlations of earthquakes with tectonic processes and features, that either the frequency of occurrence or magnitude of earthquakes may increase.

(14) More frequent occurrence of carthquakes or earthquakes of higher magnitude than is typical of the area in which the geologic setting is located.

(15) Evidence of igneous activity since the start of the Quaternary Period.

(15) Evidence of extreme erosion during the Quaternary Period.

(17) The presence of naturally occurring materials, whether identified or undiscovered, within the site, in such form that:

(i) Economic extraction is currently feasible or potentially feasible during the foreseeable future; or

(ii) Such materials have greater gross value or net value than the average for other areas of similar size that are representative of and located within the geologic setting.

(18) Evidence of subsurface rnining for resources within the site.

(19) Evidence of drilling for any purpose within the site.

(20) Rock or groundwater conditions that would require complex engineering measures in the design and construction of the underground facility or in the sealing of boreholes and shafts.
(21) Geomechanical properties that do not permit design of underground opening that will remain stable through permanent closure.

(22) Potential for the water table to rise sufficiently so as to cause satura. tion of an underground facility located in the unsaturated zone.

(23) Potential for existing or future perched water bodies that may saturate portions of the uriderground facility or provide a faster flow path from an underground facility located in the unsaturated zone to the accessible environment.

(24) Potential for the movement of radionuclides in a gaseous state through air-filled pore spaces of an unsaturated geologic medium to the accessible environment.

[48 FR 28222, June 21. 1983, as amended at $50 \mathrm{FR}$ 29647, July 22, 1985]

\section{Design CRIteria for the GeOLOGIC REPOSITORY OPERATIONS AREA}

$\$ 60.130$ Scope of design criteria for the geologic repository operations area.

Sections 60.131 through 60.134 speci. fy minimum criteria for the design of the geologic repository operations area. These design criteria are not intended to be exhaustive, however. Omissions in $\S \S 60.131$ through 60.134 do not relieve DOE from any obligation to provide such safety features in a specific facility needed to achieve the performance objectives. All design bases must be consistent with the results of site characterization activities.

\section{$\$ 60.131$ General design criteria for the} geologic repository operations area.

(a) Radiological protection. The geologic repository operations area shall be designed to maintain radiation doses, levels, and concentrations of radioactive material in air in restricted areas within the limits specified in Part 20 of this chapter. Design shall include:

(1) Means to limit concentrations of radioactive material in air;

(2) Means to limit the time required to perform work in the vicinity of radioactive materials, including, as appropriate, designing equipment for ease of repair and replacement and 
providing adequate space for ease of operation;

(3) Suitable shielding;

(4) Means to monitor and control the dispersal of radioactive contamination;

(5) Means to control access to high radiation areas or airborne radioactiv. ity areas; and

(6) A radiation alarm syst em to warn of significant increases in radiation levels, concentrations of radioactive ma erial in air, and of increased radioactivity released in effluents. The alarm system shall be designed with provisions for calibration and for testing its operability.

(b) Structures, systems, and components important to safety-(1) Protection against natural phenomena and environmental conditions. The structures, systems, and components important to safety shall be designed so that natural phenomena and environmental conditions anticipated at the geologic repository operations area will not interfere with necessary safety functions.

(2) Protection against dynamic ef. fects of equipment failure and similar events. The structures, systems, and components important to safety shall be designed to withstand dynamic effects such as missile impacts, that could result from equipment failure, and similar events and conditions that could lead to loss of their safety functions.

(3) Protection against fires and explosions. (i) The structures, systems, and components important to safety shall be designed to perform their safety fuctions during and after credible fires or explosions in the geologic repository operations area.

(ii) To the extent practicable, the geologic repository operations area shall be designed to incorporate the use of noncombustible and heat resistant materials.

(iii) The geologic repository operations area shall be designed to include explosion and fire detection alarm systems and appropriate suppression systems with sufficient capacity and capability to reduce the adverse effects of fires and explosions on structures, systems, and components important to safety. (iv) The geologic repository operations area shall be designed to include means to protect systems, structures, and components important to safety against the adverse effects of either the operation or failure of the fire suppression systems.

(4) Emergency capability. (i) The structures, systems, and components important to safety shall be designed to maintain control of radioactive waste and radioactive effluents, and permit prompt termination of operations and evacuation of personnel during an emergency.

(ii) The geologic repository operations area shall be designed to include onsite facilities and services that ensure a safe and timely response to emergency conditions and that facili. tate the use of available offsite serv. ices (such as fire, police, medical and ambulance service) that may aid in re. covery from emergencies.

(5) Utility services. (1) Each utility service system that is important to safety shall be designed so that essen. tial safety functions can be performed under both normal and accident condi. tions.

(ii) The utillty services important to safety shall include redundant systems to the extent necessary to maintain, with adequate capacity, the ability to perform their safety functions.

(iii) Provisions shall be made so that, if there is a loss of the primary electric power source or circuit, reliable and timely emergency power can be provided to instruments, utility service systems, and operating systems, including alarm systems, important to safety.

(6) Inspection, testing, and maintenance. The structures, systems, and components important to safety shall be designed to permit periodic inspection, testing, and maintenance, as necessary, to ensure their continued functioning and readiness.

(7) Criticality control. All systems for processing, transporting, handling. storage, retrieval, emplacement, and isolation of radioactive waste shall be designed to ensure that a nuclear criticality accident is not possible unless at least two unlikely, independent, and concurrent or sequential changes have occurred in the conditions essential to 
nuclear criticality safety. Each system shall be designed for criticality safety under normal and accident conditions. The calculated effective multiplication factor $\left(k_{\text {eff }}\right)$ must be sufficiently below unity to show at least a 5\% margin, after allowance for the bias in the method of calculation and the uncertainty in the experiments used to validate the method of calculation.

(8) Instrumentation and control systems. The design shall include provisions for instrumentation and control systems to monitor and control the behavior of systems important to safety over anticipated ranges for normal operation and for accident conditions.

(9) Compliance with mining regulations. To the extent that DOE is not subject to the Federal Mine Safety and Health Act of 1977, as to the construction and operation of the geologic repository operations area, the design of the geologic repository operations area shall nevertheless include such provisions for worker protection as may be necessary to provide reasonable assurance that all structures, systems, and components important to safety can perform their intended functions. Any deviation from relevant design requirements in 30 CFR, Chapter I, Subchapters D, E, and $\mathbf{N}$ will give rise to a rebuttable presumption that this requirement has not been met.

(10) Shaft conveyances used in radioactive waste handling. (i) Hoists important to safety shall be designed to preclude cage free fall.

(ii) Hoists important to safety shall be designed with a reliahle cage location system.

(iii) Loading and unloading systems for hoists important to safety shall be designed with a reliable system of interlocks that will fail safely upon malfunction.

(iv) Hoists important to safety shall be desigred to include two independent indicators to indicate when waste packages are in place and ready for transfer.

8 60.132 Additional design criteria for surface facilities in the geologic repository operations area.

(a) Facilities for receipt and retrieval of waste. Surface facilities in the geologic repository operations area shall be designed to allow safe handling and storage of wastes at the geologic repository operations area, whether these wastes are on the surface before emplacement or as a result of retrieval from the underground fa. cillty.

(b) Surface facility ventilation. Surface facility ventilation systems supporting waste transfer, inspection, decontamination, processing, or packaging shall be designed to provide protection against radiation exposures and offsite releases as provided in $\$ 60.111(a)$.

(c) Radiation control and monitoring-(1) Effluent control. The surface facilities shall be designed to control the release of radioactive materials in effluents during normal operations so as to meet the performance objectives of $\$ 60.111(\mathrm{a})$.

(2) Effluent monitoring. The effluent monitoring systems shall be designed to measure the amount and concentration of radionuclides in any effluent with sufficient precision to determine whether releases conform to the design requirement for effluent control. The monitoring systems shall be designed to include alarms that can be periodically tested.

(d) Waste treatment. Radioactive waste treatment facilities shall be designed to process any radioactive wastes generated at the geologic repository operations area into a form suitable to permit safe disposal at the geologic repository operations area or to permit safe transportation and conversion to a form suitable for disposal at an alternative site in accordance with any regulations that are applicable.

(e) Consideration of decommissioning. The surface facility shall be designed to facilitate decontamination or dismantlement to the same extent as would be required, under other parts of this chapter, with respect to equivalent activities licensed thereunder.

860.133 Additional design criteria for the underground facility.

(a) General criteria for the underground facility. (1) The orientation, geometry, layoul, and depth of the underground facility, and the design of 
any engineered barriers that are part of the underground facility shali contribute to the containment and isolation of radionuclides.

(2) The underground facility shall be designed so that the effects of credible disruptive events during the period of operations, such as flooding, fires and explosions, will not spread through the facility.

(b) Flexibility of design. The underground facility shall be designed with sufficient flexibility to allow adjustments where necessary to accommodate specific site conditions identified through in situ monitoring, testing, or excavation.

(c) Retrieval of waste. The underground facility shall be designed to permit retrieval of waste in accordance with the performance objectives of \&60.111.

(d) Control of water and gas. The design of the underground facility sha!l provide for control of water or gas intrusion.

(e) Underground openings. (1) Openings in the underground facility shail be designed so that operations can be carried out safely and the retrievability option maintained.

(2) Openings in the underground facility shall be designed to reduce the potential for deleterious rock movement or fracturing of overlying or surrounding rock.

(f) Rock excavation. The design of the underground facility shall incorporate excavation meihods that will limit the potential for creating a preferential pathway for groundwater to contact the waste packages or radionuclide migration to the accessible environment.

(g) Underground facility ventilation. The ventilation system shall be designed to:

(1) Control the transport of radioactive particulates and gases within and releases from the underground facility in accordance with the performance objectives of $\S 60.111$ (a),

(2) Assure continued function during normal operations and under accident conditions; and

(3) Separate the ventilation of excavation and waste emplacement areas.

(h) Engineered barriers. Engineered barriers shall be designed to assist the geologic setting in meeting the performance objectives for the period following permanent closure.

(i) Thermal loads. The underground facility shall be designed so that the performance objectives will be met taking into account the predicted thermal and thermomechanical response of the host rock, and surrounding strata, groundwater system.

[48 F'R 28222, June 21, 1983, as amended at 50 F'R 29648, July 22, 1985]

\subsection{Design of seals for shafts and boreholes.}

(a) General design criterion. Seals for shafts and boreholes shall be designed so that following permanent closure they do not become pathways that compromise the geologic repository's ability to meet the performance objectives or the period following permanent closure.

(b) Selection of materials and place. ment methods. Materials and placement methods for seals shall be selected to reduce, to the extent practicable:

(1) The potential for creating a preferential pathway for groundwater to contact the waste packages or

(2) For radionuclide migration through existing pathways.

[48 FR 28222, June 21, 1983, as amended at 50 F'R 29648, July 22, 1985]

\section{Design Criteria for the Waste} PACKAGE

\subsection{Criteria for the waste package} and its components.

(a) High-level-wasie package design in general. (1) Packages for HLW shall be designed so that the in situ chemical, physical, and nuclear properties of the waste package and its interactions with the emplacement environment do not compromise the function of the waste packages or the performance of the underground facility or the geologic setting.

(2) The design shall include but not be limited to consideration of the following factors: solubility, oxidation/ reduction reactions, corrosion, hydriding, gas generation, thermal effects, mechanical strength, mechanical stress, radiolysis, radiation clamage, radionuclide retardation, leaching, fire 
and explosion hazards, thermal loads, and synergistic interactions.

(b) Specific criteria for $H L W$ package design-(1) Explosive, pyrophoric, and chemically reactive materials. The waste package shall not contain explosive or pyrophoric materials or chemically reactive materials in an amount that could compromise the ability of the underground facility to contribute to waste isolation or the ability of the geologic repository to satisfy the performance objectives.

(2) Free liquids. The waste package shall not contain free liquids in an amount that could compromise the ability of the waste packages to achieve the performance objectives relating to containment of HLW (because of chemical interactions or formation of pressurized vapor) or result in splllage and spread of contamination in the event of waste package perforation during the period through permanent closure.

(3) Handling. Waste packages shall be designed to maintain waste cuntainment during transportation, emplacement, and retrieval.

(4) Unique identification. A label or other means of identification shall be provided for each waste package. The identification shall not impair the integrity of the waste package and shall be applied in such a way that the information shall be legible at least to the end of the period of retrievability. Each waste package identification shall be consistent with the waste package's permanent written records.

(c) Waste form criteria for HLW. High-level radioactive waste that is emplaced in the underground facility shall be designed to meet the following criteria:

(1) Solidification. All such radioactive wastes shall be in solid form and placed in sealed containers.

(2) Consolidation. Particulate waste forms shall be consolidated (for example, by incorporation into an encapsulating matrix) to limit the availability and generation of particulates.

(3) Combustibles. All combustible radioactive wastes shall be reduced to a noncombustible form unless it can be demonstrated that a fire involving the waste packages containing combustibles will not compromise the integrity of other waste packages, adversely affect any structures, systems, or components important to safety, or compromise the ability of the underground facility to contribute to waste isolation.

(d) Design criteria for other radioactive wastes. Design criteria for waste types other than HLW will be addressed on an individual basis if and when they are proposed for disposal in a geologic repository.

\section{Performance Confirmation REQUIREMENTS}

\section{\$60.137 General requirements for per-} formance confirmation.

The geologic repository operations area shall be designed so as to permit implementation of a performance confirmation program that meets the requirements of Subpart $F$ of this part.

\section{Subpart F-Performance Confirmation Program}

SourCE: 48 FR 28228, June 21, 1983, unless otherwise noted.

\section{$\$ 60.140$ General requirements.}

(a) The performance confirmation program shall provide data which indicates, where practicable, whether:

(1) Actual subsurface conditions en. countered and changes in those conditions during construction and waste emplacement operations are within the limits assumed in the licensing review; and

(2) Natural and engineered systems and components required for repository operation, or which are designed or assumed to operate as barriers after permanent closure, are functioning as intended and anticipated.

(b) The program shall have been started during site characterization and it will continue until permanent closure.

(c) The program shall include in situ monitoring, laboratory and fielo testing, and in situ experiments, as may be appropriate to accomplish the objective as stated above.

(d) The program shall be implemented so that:

(1) It does not adversely affect the ability of the natural ard engineered 
elements of the geologic repository to meet the performance objectives.

(2) It provides baseline information and analysis of that information on those parameters and natural processes pertaining to the geoiogic setting that may be changed by site characterization, construction, and operational activities.

(3) It monitors and analyzes changes from the baseline condition of param. eters that could affect the performance of a geologic repository.

(4) It provides ar established plan for feedback and analysis of data, and implementation of appropriate action.

\section{\$ 60.141 Confirmation of geotechrical and design parameters.}

(a) During repository construction and operation, a continuing program of surveillance, measurement, testing. and geologic mapping shall be conducted to ensure that geotechnical and design parameters are confirmed and to ensure that appropriate action is taken to inform the Commission of changes needed in design to accommodate actual field conditions encouncered.

(b) Subsurface conditions shall be monitored and evaluated against desien assumptions.

(c) As a minimum, measurements shall be made of rock deformations and displacement, changes in rock stress and strain, rate and location of water inflow into subsurface areas, char es in grcundwater conditions, rock pore water pressures including those along fractures and ioints, and the thermal and thermomechanical respunse of the rock mass as a result of development and operations of the geologic $r \equiv$ pository.

(d) These meas'rements and observations shall be compared with the uriginal design bases and assumptions. If significant differences exist between the measurements and observations and the original design bases and assumptions, the need for modifications to the design or in construction methods sha.l be determined and these difzrences and the recommended changes reported to the Commission.

(e) In situ monitoring of the thermomechanical response of the underground facility shall be conducted until permanent closure to ensure that the performance of the natural and engineering features are within design limits.

\section{\$ 60.142 Design testing.}

(a) During the early or developmental stages of construction, a program for in situ testing of such features as borehole and shaft seals, backfill, and the thermal interaction effects of the waste packages, backfill, rock, and groundwater shall be conducted.

(b) The testing shall be initiated as early as is practicable.

(c) A backfill test section shall be constructed to test the effectiveness of backfill placement and compaction procedures against design requirements before permanent backfill placement is begun.

(d) Test sections sha!l be established to test the effectiveness of borehole and shaft seals before full-scale operation proceeds to seal boreholes and shafts.

\section{$\$ 60.143$ Monitoring and testing waste packages.}

(a) A program shall be established at the geologic repository operations area for monitoring the condition of the waste packages. Waste packages chosen for the program shall be representative of those to be emplaced in the underground facility.

(b) Consistent with safe operation at the geologic repository operations area, the environment of the waste packages selected for the waste package monitoring program shall be representative of the environment in which the wastes are to be emplaced.

(c) The waste package monitoring program shall include laboratory experiments which focus on the internal condition of the waste packages. To the extent practical, the environment experienced by the emplaced waste packages within the underground facility during the waste package monitoring program shall be duplicated in the laboratory experiments.

(d) The waste package monitoring program shall continue as long as practical up to the time of permanent closure. 


\section{Subpart G-Quality Assurance}

SoURCE: 48 FR 28228, June 21, 1983, unless otherwise noted.

\subsection{Scope.}

As usec' in this part, "quality assurance" comprises all those planned and systematic actions necessary to provide adequate confidence that the geologic repository and its subsystems or components will perform satisfactorily in service. Quality assurance includes quality control, which comprises those quality assurance actions related to the physical characteristics of a material, structure, component, or system which provide a means to control the quality of the material, structure, component, or system to predetermined requirements.

\subsection{Applicability.}

The quality assurance program applies to all systems, structures and components important to safety, to design and characterization of barriers important to waste isolation and to activities related thereto. These activities include: site characterization, facility and equipment construction, facility operation, performance confirmation, permanent closure, and decontamination and dismantling of surface facilities.

$\$ 60.152$ Implementation.

DOE shall implement a quality assurance program based on the criteria of Appendix B of 10 CFR Part 50 as applicable, and appropriately supplemented by additional criteria as required by $\S 60.151$.

\section{Subpart H-Training and Certification of Personnel}

SOURCE: 48 F'R 28229, June 21, 1983, unless otherwise noted.

\section{\$60.160 General requirements.}

Operations of systems and components that have been identified as important to safety in the Safety Analy. sis Report and in the license shall be performed only by trained and certified personnel or by personnel under the direct visual supervision of an individual with training and certification in such operation. Supervisory personnel who direct operations that are important to safety must also be certified in such operations.

\subsection{Training and certification pro- gram.}

DOE shall establish a program for training, proficiency testing, certification and requalification of operating and supervisory personnel.

\subsection{Physical requirements.}

The physical condition and the general health of personnel certified for operations that are important to safety shall not be such as might cause operational errors that could endanger the public health and safety. Any condition which might cause impaired judgment or motor coordination must be considered in the selection of personnel for activities that are important to safety. These conditions need not categorically disqualify a person, so long as appropriate provisions are made to accommodate such conditions.

\section{Subpart I-Emergency Plarining Criferia [Reserved]}



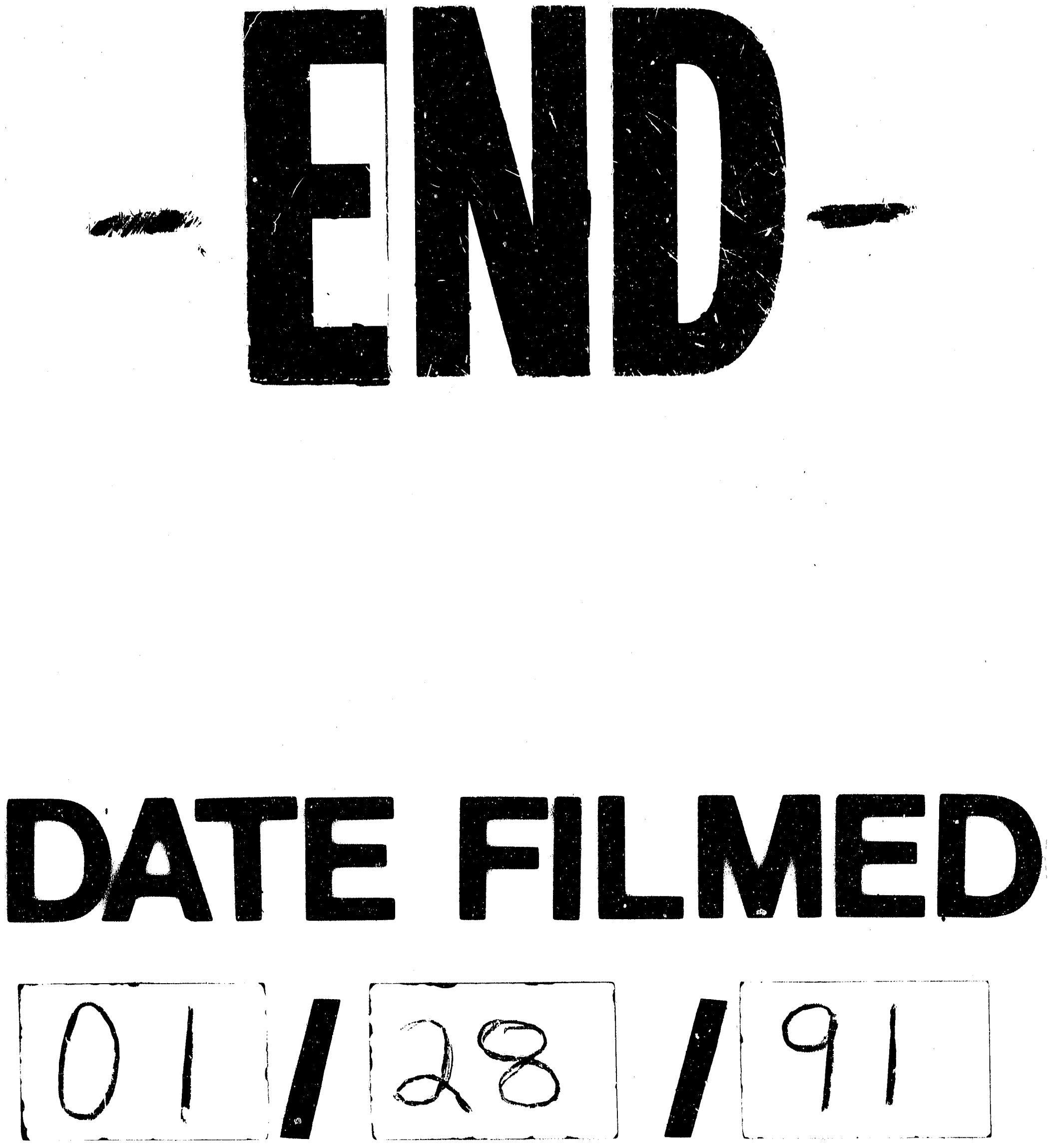


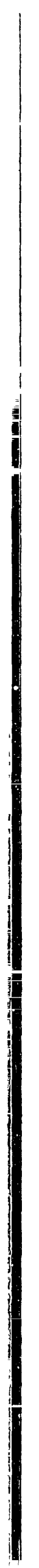

